\title{
COMMENT
}

\section{PUBLIC PARTICIPATION IN FEDERAL ADMINISTRATIVE PROCEEDINGS}

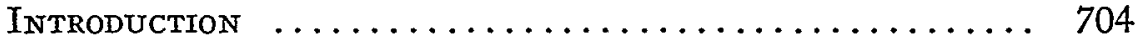

I. Toward a Theory of Public Participation ........ 707

A. The Agencies and the Public ............. 707

B. The Courts and Public Participation in Agency Decisionmaking .......................... 709

C. Pursuing "The Public Interest" ............. 723

1. The Decisionmaking Model ............. 723

2. Public Interest Groups ................ 730

D. Considerations Influencing the Form of Participation .. 735

E. Proposals to Facilitate Public Participation ........ 746

II. An Analysts of Five Agencies' Experience with Public Participation ................... 751

A. Federal Communications Commission .......... 751

1. Standing Before the FCC ............. 754

2. The Discretionary Hearing $\ldots \ldots \ldots \ldots \ldots \ldots 761$

3. The Procedural Rights and Bargaining Power of the

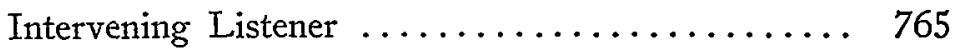

4. Financing Public Advocacy .............. 768

5. Conclusion $\ldots \ldots \ldots \ldots \ldots \ldots \ldots \ldots \ldots \ldots \ldots \ldots$ 
B. Civil Aeronautics Board ................ 773

1. Modes of Participation .............. 774

a. Judicial Review and Evasion of Public Participation ........................ 775

b. Participation as Parties .............. 777

c. Informal Participation ................ 779

2. A Proposal $\ldots \ldots \ldots \ldots \ldots \ldots \ldots \ldots \ldots \ldots . \ldots \ldots 4$

C. Federal Trade Commission ................ 788

1. Informal Proceedings ................. 789

2. Formal Adjudicative Proceedings ............. 798

3. Appeals of Commission Orders ........... 806

4. Funding Public Participation ............ 811

D. Federal Agencies Regulating Power Generation ..... 812

1. Federal Power Commission ............. 813

a. The Natural Gas Act ................ 815

b. The Federal Power Act ............... 818

c. The Public Interest and the Power Commission . . 821

2. Atomic Energy Commission ............. 825

a. The Licensing Proceeding ............ 826

b. Intervention Before the AEC .......... 828

c. Standing of Parties to Raise Particular Issues ... 834

(i) Challenges to the Applicant's Safety Analysis 834

(ii) Challenges to Environmental Effects ..... 835

d. Conclusion ...................... 839

3. Proposals to Unify Power Plant License Decisionmaking $\ldots \ldots \ldots \ldots \ldots \ldots \ldots \ldots \ldots \ldots \ldots \ldots$

III. Concluston $\ldots \ldots \ldots \ldots \ldots \ldots \ldots \ldots \ldots \ldots \ldots \ldots \ldots \ldots$ 


\section{INTRODUCTION}

Federal administrative agencies are under attack. Their alleged failure to perform their functions in accordance with the public interest has led to numerous proposals for reform-among them, proposals for increased public participation in agency proceedings. This Comment will consider a rather technical subject having important practical implications: the mechanisms, fashioned by statutes, administrative regulations and policies, and judicial decisions, by which groups seeking to represent or promote the public interest are permitted to participate in certain proceedings of the Federal Communications Commission (FCC), Civil Aeronautics Board (CAB), Federal Trade Commission (FTC), Atomic Energy Commission (AEC), and Federal Power Commission (FPC).

The first part of this Comment will survey recent criticism of federal administrative agencies. It will next discuss the legal basis of public participation before the agencies and its relationship to the law of standing to obtain judicial review of administrative action. It will then explore the underlying problems in constructing a regulatory model, defining the public interest and public interest groups, and determining the ideal role such groups should play within the regulatory model. It will proceed to analyze the considerations that currently shape agency discretion in permitting public interest participation in relation to the effect such participation has actually had upon agency proceedings. Finally, it will assess certain proposals to facilitate more productive public interest participation.

In the second part, the Comment will set forth the particular statutory and factual situation confronting each agency, and attempt to focus upon distinctive problems within the experience of each agency which may provide some lessons for agencies in general. The FCC discussion will examine the control third parties may exert over the determinations when to convene and whether to settle a broadcast license renewal hearing. The CAB section will focus on the structuring of public participation within a hearing itself. The FTC analysis will approach the problems of contouring and limiting public participation in informal and formal enforcement proceedings. Finally, the AEC and the FPC will be examined jointly in order to focus on their status as regulators of segments of the power industry: the highly technical nature of the subject matter and the complicated nature of the proceedings involved in power plant construction licensing occasion some concern whether public participation can be effective and, if not, whether alternative means of improving agency policymaking may be necessary.

The recent change in attitude toward public participation may be illustrated by contrasting two instances of judicial review of the treatment accorded applicants for participation in administrative proceedings. In 1955, the Court of Appeals for the District of Columbia 
Circuit, in Kansas City Power \& Light Co. v. McKay, ${ }^{1}$ reversed a district court's grant of standing to several electric utility companies attempting to attack certain Rural Electrification Administration contracts. The plaintiff utility companies alleged the contracts would enable five federated cooperatives to engage in "destructive federally-subsidized competition" with them. The court interpreted the provision of the Administrative Procedure Act (APA) ${ }^{2}$ granting standing to obtain judicial Review to "[a] person suffering legal wrong . . . or adversely affected or aggrieved by agency action within the meaning of a relevant statute" ${ }^{3}$ as merely preservative of prior case law governing standing. That law, the court pointed out, gave the appellants no enforceable legal right to be free of such competition. Quoting the Supreme Court's opinion in Alabama Power Co. v. Ickes, ${ }^{4}$ the court suggested its reasons for its narrow construction of the APA provision. ${ }^{5}$ The court concluded by asserting broadly that

[c]learly, plaintiffs' interest as citizens, property owners, or franchise holders considered separately from, and not merely in aid of, their right to challenge alleged unlawful competition, confers no standing upon them to challenge defendants' actions in the courts. Merely as such, their status is no different from that of ordinary taxpayers who would not have standing to sue here. Commonwealth of Massachusetts v. Mellon, 262 U.S. 447 . . (1923). ${ }^{6}$

The federal administrative agencies, performing roles created by Congress, were not lightly to be disturbed by the courts or the citizenry.

Fifteen years later, the same court decided National Welfare Rights Organization v. Finch. ${ }^{7}$ Under the Social Security Act, the Secretary of Health, Education, and Welfare was responsible for supervising distribution of federal funds to state welfare assistance programs and, if a state did not conform to federal statutory conditions, for discontinuing payments after notice and a hearing. ${ }^{\$}$ Congress had expressly conferred on the states both the right to a hearing ${ }^{9}$ and judicial review. ${ }^{10}$ Other potential complainants were not given standing to appeal, either indirectly by creation of a statutory "right" or by other express statutory provision, nor were they provided an opportunity to intervene in con-

1225 F.2d 924 (D.C. Cir.), cert. denied, 350 U.S. 884 (1955).

25 U.S.C. $\$ \$ 551-59,701-06$ (1970).

3 Id. $\$ 702$.

4302 U.S. 464,480 (1938).

5225 F.2d at 928 .

6 Id. at 933 .

7429 F.2d 725 (D.C. Cir. 1970).

8 See 42 U.S.C. $\$ 1316$ (1970).

9 Id. $\$ 1316$ (a) (2).

$10 I d . \$ 1316(\mathrm{a})(3)$. 
formity hearings. It was not entirely clear in Welfare Rights just who was attacking the agency or what injury was being inflicted on the plaintiff, an organization of welfare recipients: as one of the NWRO attorneys commented later, the attorneys themselves had selected their client. $^{11}$ Times, and judicial attitudes, had apparently changed, however. The court held that the NWRO had standing to obtain review and, further, the right to be admitted as a party in the administrative hearing below. ${ }^{12}$

If the new kind of litigant now appearing before the agencies and the courts is a strange beast, ${ }^{13}$ both its acceptance by the courts as a participant in the labyrinth of federal administrative agencies and the law the courts have constructed to accommodate it are stranger yet. Indeed, because lawyers have long been bringing their "own" lawsuits, ${ }^{14}$ the change in the nature of the litigant may not be as startling as the change in the view of the administrative agencies held by the public and the courts.

For there has indeed been a revolution in the scope of public participation ${ }^{15}$ in agency proceedings. Organic statutes were, in the heyday of optimism over governmental regulation, construed as vesting in the agencies the power within very wide limits both to define and to carry out public policy. ${ }^{16}$ Judicial review and the right to be heard before the agency were available only when the agency interfered with

11 See Wexler, Practicing Law for Poor People, 79 Yale L.J. 1049, 1062 (1970). 12429 F.2d at 734-37.

13 See generally Berlin, Roisman \& Kessler, Public Interest Law, 38 Geo. WASH. L. Rev. 675 (1970) ; Cahn \& Cahn, Power to the People or the Profession?-The Public Interest in Public Interest Law, 79 YALE L.J. 1005 (1970); Halpern \& Cunningham, Reflections on the New Public Interest Law: Theory and Practice at the Center for Law and Social Policy, 59 GEo. L.J. 1095 (1971); Wexler, supra note 11; Comment, The New Public Interest Lawyers, 79 YaLE L.J. 1069 (1970).

14 See generally C. Markmann, The Noblest Cry: A History of the AmeriCAN CiviL LIBERTIES UNION (1965).

15 The term "participation" will refer to all types of nongovernment activity before an administrative agency. "Intervention" in its most technical sense means entering a proceeding initiated by others with all the procedural rights of original parties. See BLACK's LAW DictionaRy 956 (4th ed. 1968). In its broader sense, the term includes participation in a proceeding with procedural rights which are often more limited than those of original parties. Unless otherwise indicated, the term is used here throughout in this broader, non-technical sense.

16

The need was for an arm of government which would be judiciary, executive and legislature all rolled into one efficient and expert machinery for regulation. The trouble at the root of this idea was that its proponents held to a totally fallacious idea of how a decision can be made. They thought there was an "administrative" decision, somewhere in between a judicial and a legislative decision and partaking of both, which could be made by expertsand only by experts.

Griffiths, unpublished essay, quoted in Reich, The Law, of the Planned Society, 75 YALE L.J. 1227, 1235 (1966). Compare Judge Kaufman's characterization of the "New Deal concept of administrative agencies as pristine, technocratic, and autocratic automatons methodically perceiving and promulgating the general will, unsullied by the political wars that surge about them." Kaufman, Power for the People-and by the People: The Utilities, the Environment, and the Public Interest, 88 PuB. UTr. FORT. 90, 94 (1971). 
the legally protected interests of individuals. Today, with regulation more suspect, the judiciary has taken steps to ensure the opportunity to review all but the most insulated agency policy formulation and to require that the agencies carefully consider and include in a record any responsible policy position urged upon them. Requiring public participation has become, in part, a technique for forcing the agencies to engage in open, debated policy formulation and to construct a record more likely to facilitate judicial examination of the process and the result.

\section{Toward a Theory of Public Participation}

Generalization in administrative law is admittedly dangerous. There is, however, helpful perspective in such an approach occasionally justifying the attempt. Throughout this Comment an effort will be made to minimize the necessary difficulties by focusing as much as possible on public intervention in adjudicatory hearings as set out under section 6 of the APA, and on appeals from agency action as governed by section 10 .

\section{A. The Agencies and the Public}

Attacks on federal administrative agencies are widespread. ${ }^{17}$ One of the most common criticisms is that the interests of large segments of the public are not adequately represented in agency proceedings affecting them and that the agencies are not sufficiently accountable to the public. ${ }^{18}$ It is further charged that agencies are, to varying degrees,

17 The most telling recent criticism comes from two men intimately acquainted with agency decisionmaking at the highest level, former Commissioner Elman of the FTC and Commissioner Johnson of the FCC. See generally Elman, Administrative Reform of the Federal Trade Commission, 59 GEo. L.J. 777 (1971) ; Elman, $A$ Modest Proposal for Radical Reform, 56 A.B.A.J. 1045 (1970); Johnson, $A$ New Fidelity to the Regulatory Ideal, 59 GEo. L.J. 869 (1971). See also P. MACAvoy, THE CrIsIS of the Regulatory Commissions (1970) ; President's Advisory Councrl on Executive Organization, A New Regutatory Franework: Report on Selected IndePENDENT Regulatory Agencies (1971) (the "Ash Council Report").

18 This criticism sounded as a refrain throughout the 1970 hearings on the proposed Public Counsel Corporation. See genterally Hearings on S. 3434 \& S. 2544 Before the Subcomm. on Adninistrative Practice \& Procedure of the Senate Comm. on the Judiciary, 91st Cong., 2d Sess. (1970). See also Bonfield, Representation for the Poor in Federal Rulemaking, 67 MrcH. L. Rev. 511 (1969); Cahn \& Cahn, The New Sovereign Immmunity, 81 HARV. I. REV. 929, 957-69 (1968). In response, the Administrative Conference of the United States has recently recommended several proposals which would accord inadequately represented interests more opportunity to participate in agency proceedings. Administrative Conference of the United States, Recommendation 28, adopted Dec. 7, 1971; see Gellhorn, Public Participation in Administralive Proceedings, 81 YALE L.J. 359 (1972) (based upon a report to the Committee on Agency Organization \& Procedure of the Administrative Conference).

A number of public interest organizations have sponsored a set of model intervention rules. See 116 CoNG. REc. 18,939, 18,942 (daily ed. Nov. 25, 1970). The model rules allow intervention in any agency adjudication, rulemaking, ratemaking, or licensing proceeding or "any other proceeding that may result in an order, sanction, or relief as defined in [ $\$ 2$ of the APA, 5 U.S.C. $\$ 551$ (1970)]," if the applicant's "pecuniary or economic interest is exclusively that of a consumer or is otherwise representative of the general public or of a particular geographical area, and if 
too much under the influence of the interests they regulate, ${ }^{19}$ and that appointments to high agency positions are too often made on the basis of sheer accommodation of those interests. ${ }^{20}$ Emphasis on agency expertise, it is said, means that some issues are ignored and others framed in such technical terms that non-experts and members of the general public wishing to speak to those issues are either overwhelmed by technical jargon or politely ignored. ${ }^{21}$ Indeed, in some contexts, hearings seem to serve only to legitimate decisions already made by agency staff. $^{22}$ The public is unaware of the content and significance of formal agency proceedings, and virtually no one except the parties directly affected is aware of the content and significance of informal proceedings, many of which are conducted in private. ${ }^{23}$ Investigatory facilities are said to be inadequate in some agencies to monitor the activities of the regulated interests. ${ }^{24}$ Jurisdictional conflicts among agencies ${ }^{25}$ make difficult the implementation of articulated national policies such as that embodied in the National Environmental Policy Act (NEPA).$^{26}$ Congress seems reluctant to pass major legislation to facilitate public awareness and active participation. ${ }^{27}$ It is suggested that certain members of Congress exert a good deal of informal influence ${ }^{28}$ over some activities of independent agencies that might be jeopardized by significant restructuring. Former Commissioner Elman of the FTC has noted a reluctance within that agency to make its organizational problems known to Congress. ${ }^{29}$ Responses of other agencies to a 1969

participation by such person under the ordinary rules of practice would be unduly burdensome." An intervenor would have "all the rights of a party, including the right to appeal any initial decision" of the agency to the same extent as a party. The rules further provide for filing of single copies of documents, access to transcripts, subpoena powers, "reasonable legal assistance" from the agency's legal staff for intervenors who cannot retain counsel, and notice to "persons who have communicated to the Agency an interest in any subject matter or geographical area" within its jurisdiction of any proceeding that may affect that subject matter or area.

19 See, e.g., M. BERNSTEIN, REgulating BUSINESS BY INDEPENDENT COMMISSION 86-102 (1955); R. Fellmeth, The Interstate Comamerce OMrssion 15-22 (1970); Lazarus \& Onek, The Regulators and the People, 57 VA. L. Rev. 1069 (1971).

${ }_{20} C f$. Johnson, supra note 17 , at 895.

21 See, e.g., Jowell, The Limits of the Public Hearing as a Tool of Urban Planning, 21 Áp. L. Rev. 123, 143 (1969); Plager, Participatory Democracy and the Public Hearing: A Functional Approach, 21 AD. L. REv. 153, 156 (1969).

22 See notes 876-81 infra \& accompanying text.

23 See notes 594, 678 infra \& accompanying text. See also K. DAvrs, AdmrnrsTRATIVE LAW TREatrSe $\$ \$ 4.12-.13$ (Supp. 1970) [hereinafter cited as K. Davis (1958 ed. unless otherwise indicated)]; Lazarus \& Onek, supra note 19, at 1095 .

24 See, e.g., Johnson, supra note 17, at 881. See also notes 448, 624 infra \& accompanying text.

25 See generally 3 K. Davis, supra note 23, § 19.09 (1958 \& Supp. 1970) ; Reich, supra note 16 , at 1237 .

2642 U.S.C. $\$ \$ 4321-47$ (1970).

27 See notes 303-05 infra \& accompanying text (Public Council Corporation); cf. notes 306-21 infra \& accompanying text (Consumer Protection Agency).

28 See, e.g., Johnson, supra note 17, at 905 ; cf. ABA Comarssion to Study the Federal Trade Commisston, Report 33 (1969).

29 Elman, Administrative Reform of the Federal Trade Commission, 59 GEo. L.J. 777, 780 (1971) ; cf. E. Cox, R. Fellmeth \& J. Schulz, The Consumer and the Federal Trade Comarssion, reprinted int 115 Cong. Rec. 1539, 1545 (Jan. 22, 1969). 
questionnaire of the Senate Subcommittee on Administrative Practice and Procedure, which asked for an evaluation of citizen input and agency responsiveness, reveal a similar self-satisfaction..$^{30}$ Finally, the standard of judicial review of agency action ${ }^{31}$ is thought to be too narrow both in terms of review of findings of facts and in terms of unwillingness to review action committed to agency discretion. ${ }^{32}$ Thus, pessimistically viewed, the agencies are too much under the influence of regulated interests and too insulated from judicial scrutiny; there is little movement in Congress toward reforming them; and certain interests shared by large segments of the public are inadequately represented before them. Regardless of the validity of any of these criticisms, the lack of public confidence they suggest may in itself seriously impair the efficacy of the administrative process.

\section{B. The Courts and Public Participation in Agency Decisionmaking}

At least concurrently with the expansion of public criticism of, and interest in participation in, agency proceedings, courts have expanded the scope of standing to challenge determinations made in those proceedings. In some cases where agencies have not voluntarily allowed intervention to a class of individuals broader than that granted standing to seek judicial review, courts have expanded the opportunity to intervene. Professor Jaffe has observed that

[t] here are two closely related motifs: whether an action is in any likely case reviewable at all ... and whether the particular petitioner is a proper party to secure review. An opinion denying review may rest on the proposition that judicial scrutiny as such is excluded by statute or by general considerations of impropriety. . . . Or it may bear down on the lack of legal interest or "standing" of the plaintiff to secure review. . . . [I]f the class of persons most nearly affected does not have standing the action is for all practical purposes nonreviewable. ${ }^{33}$

The trend is toward review. Thus, the District of Columbia Circuit in Environmental Defense Fund, Inc. v. Ruckelshaus ${ }^{34}$ declared:

We stand on the threshold of a new era in the history of the long and fruitful collaboration of administrative agencies

30 Subcomin. on Administrative Practice \& Procedure of the Senate Comm. on the Judictary, 91st Cong., 1st Sess., Responses to Questionnatre on Citizen Involvenent and Responstve AgENCY DECISTON-MAKIng 5-16 (CAB), 19-29, 51-71 (FCC) (Comm. Print 1969) [hereinafter cited as Responses].

31 See notes 136-54 infra \& accompanying text.

32 See generally $4 \mathrm{~K}$. DAvIs, supra note 23, \$\$28.01-.21; Elman, supra note 29, at 785-94; Johnson, supra note 17, at 904-05.

33 L. Jaffe, Judiciar Control of Administrative Action 336-37 (1965) (emphasis supplied). See also Saferstein, Nonreviewability: A Functional Analysis of "Committed to Agency Discretion," 82 HaRv. L. Rev. 367 (1968).

34439 F.2d 584 (D.C. Cir. 1971). 
and reviewing courts. For many years, courts have treated administrative policy decisions with great deference, confining judicial attention primarily to matters of procedure. On matters of substance, the courts regularly upheld agency action, with a nod in the direction of the "substantial evidence" test, and a bow to the mysteries of administrative expertise. Courts occasionally asserted, but less often exercised, the power to set aside agency action on the ground that an impermissible factor had entered into the decision, or a crucial factor had not been considered. Gradually, however, that power has come into more frequent use, and with it, the requirement that administrators articulate the factors on which they base their decisions. ${ }^{35}$

An examination of the current relationship between standing to appeal and opportunity to participate on the agency level suggests that expansion of the latter is more directly related to a desire to review policy decisions than to solicitude for the legal rights of the particular plaintiff. Three related generalizations about the cases seem appropriate. First, where a hearing is required to be held by an agency, no case appears to have approved the agency's denial of intervention to one the court held to have standing to appeal, except in the narrow situation where some party other than the agency was found to "represent the same interest" and was admitted. ${ }^{36}$ Second, in those cases where a petitioning party was properly excluded from a hearing below on that ground, and where the party permitted to intervene failed to appeal, the excluded party has been granted standing to appeal. ${ }^{37}$ Judicially articulated or not, the effect of these two phenomena is to help ensure that the maximum number of judicially reviewable issues has a plaintiff to bring them before the court with a record developed below that reflects at least that plaintiff's policy position. These cases, however, do not provide either opportunity to intervene or opportunity to appear before a court to all persons or groups raising those issues. Although this result is accomplished by finding that the party admitted to and the party excluded from any particular proceeding had the same "interest," this "test" is unlike the one applied, for example, in conventional situations involving questions of privity of contract. As the analysis below will suggest, it is doubtful whether current doctrines of standing retain a requirement of a "legally protected right" in which two or more individuals could be said to have something resembling a common "property interest." 38 Third, there is some language in recent cases

35 Id. at 597.

30 Cf. Office of Communication of the United Church of Christ v. FCC, 359 F.2d 994 (D.C. Cir. 1966).

37 See Shapiro, Some Thoughts on Intervention Before Courts, Agencies, and Arbitrators, 81 HaRv. L. REv. 721, 767 (1968).

38 See text accompanying notes 49-84 infra. 
suggesting that the opportunity to participate in agency proceedings must be available to every party having standing to appeal the agency's action. While such a formulation would eliminate the problem of determining "identity" of interests, it does not seem to recognize the practical necessity for controlling the size of the proceedings. The oldest and clearest group of cases in this line involved agencies as to which the statutory language governing intervention was, on its face, entirely permissive, but was read as mandatory, when considered in light of the statutory context allowing appeals only by parties. The right to appeal depended on whether party status was enjoyed below, and whether that status was, on the face of the statute, discretionary with the agency. In National Coal Association v. FPC ${ }^{39}$ the Court of Appeals for the District of Columbia Circuit held that a competitor had standing to appeal an FPC natural gas pipeline certificate award. Relying on a provision of the statute limiting appeal to aggrieved parties in the proceeding below, the court found that a competitor who would be aggrieved by an FPC order had a right to intervene. ${ }^{40}$ More recent cases in the Second and District of Columbia Circuits have suggested that intervention may be required in order to make the right of review effective. National Welfare Rights Organization $v$. Finch ${ }^{41}$ involved an organic statute which immunized the Secretary's ultimate findings of fact from review, unless unsupported by substantial evidence, and required remand to the agency rather than review de novo by the courts. $^{42}$ Judge Wright felt that the power to remand did not adequately ensure the effective review sought by the petitioning welfare recipients' organization and that at least limited participation below was required. ${ }^{43}$ Judge Wright's argument relating intervention to the statutory language seemed an afterthought to the broad assertion that " $[t]$ he right of judicial review cannot be taken as fully realized . . . , if appellants are excluded from participating in the proceeding to be reviewed." 44

The rumblings are equally audible in the Second Circuit, although not quite as strong, perhaps, as Professor Davis has indicated in his assertion that " $[t]$ he Second Circuit seems to adopt a rule that a party having the right of judicial review must have the right of intervention." 45 The case Davis noted, American Communications Association v. United States, ${ }^{46}$ explicitly referred to National Coal's holding that intervention below was required in order to secure the right to review (under a statute that conditioned review upon having attained party

39191 F.2d 462 (D.C. Cir. 1951).

$40 \mathrm{Id}$. at 467.

41429 F.2d 725 (D.C. Cir. 1970).

4242 U.S.C. $\$ 1316(\mathrm{a})(4)$ (1970). See also id. $\$ 1316(\mathrm{a})(5)$.

43429 F.2d at 737.

44 Id. at 736.

451 K. Davrs, supra note $23, \S 8.11$, at 388 (Supp. 1970).

46298 F.2d 648 (2d Cir. 1962). 
status below), and held that, even in the absence of an identical statutory context, intervention in the present case was necessary to secure an effective right to review. ${ }^{47}$

No court has yet gone so far as to require intervention by every party entitled to appeal an agency determination. In some situations, review can arguably be effective without participation of the appellant in the proceedings below. In many proceedings, however, where some broad interest affected might be promoted by the adoption of any one of a number of policy positions, and the fairness of the decisionmaking process turns not so much on the verification of factual data (which might be effectively presented by only one party) as on the resolution of conflicting policy positions (which are best presented by a variety of different parties), "identity of interest" is a difficult test to apply in excluding potential participants from agency proceedings, or, for that matter, potential appellants from full participation in judicial review. The goal of public participation should be the fullest feasible debate on the issues, rather than the "representation" of broadly or narrowly defined "interests." 48

If the judicial standing rule were well defined or narrowly circumscribed, it might be possible to define the minimum scope of the right to intervene by reference to the maximum scope of standing to obtain judicial review (leaving the agencies with discretion to permit fuller participation in appropriate cases). The rule, however, seems to have approached the case-or-controversy limit imposed by the Constitution, and is consequently both vague and expansive: as the following analysis will demonstrate, the courts have made the concept of an "interest" conferring standing to obtain review very flexible, and hence unreliable as a standard for choosing worthy participants in agency proceedings.

Although the two are related, it is important to distinguish standing before courts to initiate review of administrative action from standing before agencies to intervene in their proceedings. ${ }^{49}$ Except

$47 \mathrm{Id}$. at $650-51$.

48 See notes $162-67$ infra \& accompanying text.

49

Since both standing to obtain review and the right to intervene in an administrative proceeding involve a determination of what interests are deserving of legal protection, one might initially suppose that the law governing intervention and standing would be about the same. But many factors affect one and not the other. Statutes concerning intervention usually differ from those concerning review. The central problem of intervention is usually the disadvantage to the tribunal and to other parties of extended cross-examination; judicial review involves no such problem. Adequate protection for interests obliquely affected may often be afforded through limited participation; no such compromise concerning judicial review is customary. No constitutional restrictions affect intervention; standing to obtain review is substantially affected by the constitutional requirement of case or controversy. Intervention means mere participation in a proceeding already initiated by others; obtaining judicial review normally means instituting an entirely new judicial proceeding.

$3 \mathrm{~K}$. Davis, supra note $23, \S 22.08$, at 241. See also 1 id. $\S 8.11$, at 564; Davis, Standing to Challenge and to Enforce Adninistrative Action, 49 Colun. L. Rev. 759, 76872 (1949). 
to the extent that statutes preclude judicial review, ${ }^{50}$ or agency action is committed to agency discretion, ${ }^{51}$ standing for purposes of judicial review is governed by section 10 of the Administrative Procedure Act:

A person suffering legal wrong because of agency action, or adversely affected or aggrieved by agency action within the meaning of a relevant statute, is entitled to judicial review thereof. ${ }^{52}$

This right of review was first held, in the absence of a broader provision in the organic statute of an agency, ${ }^{53}$ merely to codify pre-existing case law, which had conferred standing only when the plaintiff was threatened with or had suffered a "legal wrong," ${ }^{54}$ presumably the correlative of a "legal right," which the Supreme Court had described as "one of property, one arising out of contract, one protected against tortious invasion, or one founded on a statute which confers a privilege." 55 In 1968 the Supreme Court held that a private utility alleging improper expansion of TVA services into its market area should be granted standing where there was an implicit congressional intent in the organic statute to benefit it. ${ }^{56}$

In 1970 the Court decided Association of Data Processing Service Organizations v. Camp ${ }^{57}$ and Barlow v. Collins. ${ }^{58}$ These companion cases completely rejected the legal wrong test and substituted in its place the rule that a plaintiff has standing if he alleges that "the challenged action has caused him injury in fact, economic or otherwise" 59 and that the injured interests are "arguably within the zone of interests

505 U.S.C. $\$ 701$ (a) (1) (1970).

51 Id. $\$ 701$ (a) (2).

52 Id. $\$ 702$.

53 In FCC v. Sanders Bros. Radio Station, 309 U.S. 470 (1940), the Court granted the plaintiff standing to challenge the grant of a license to a competitor under the Federal Communications Act, which provided for appeal by "any other person aggrieved or whose interests are adversely affected by any decision of the Commission granting or refusing any such application [for an operating license]." Communications Act of 1934, Pub. L. No. 73-416, $\$ 402(\mathrm{~b})(2), 48$ Stat. 1093, as amended, 47 U.S.C. $\$ 402$ (b) (6) (1970). The Court felt that the legislative history permitted a broad reading of the provision and that a competitor might be the only party with sufficient interest to challenge illegal agency action. 309 U.S. at 477. In Associated Indus., Inc. v. Ickes, 134 F.2d 694, 704 (2d Cir.), vacated as moot, 320 U.S. 707 (1943), the Second Circuit made the theory more explicit: a competitor might act as a "private Attorney General" to "vindicate the public interest" by assuring compliance with the law. Generally, the courts have allowed challenges to administrative action by competitors where it is felt that no other party is sufficiently disadvantaged or has sufficient incentive to seek judicial review. $C f$. notes 136-54 infra \& accompanying text.

54 See Kansas City Power \& Light Co. v. McKay, 225 F.2d 924 (D.C. Cir.), cert. denied, 350 U.S. 884 (1955).

55 Tennessee Elec. Power Co. v. TVA, 306 U.S. 118, 137-38 (1939).

56 Hardin v. Kentucky Util. Co., 390 U.S. 1, 7 (1968).

57397 U.S. 150 (1970).

68397 U.S. 159 (1970).

59397 U.S. at 152. 
to be protected or regulated by the statute or constitutional guarantee in question." "60 The Court noted that these interests included noneconomic ones, such as conservation and aesthetics. ${ }^{61}$ The test has been much discussed and criticized. ${ }^{62}$ Professor Davis has argued that the test is wrong, insofar as it requires a determination that the interest is protected by the statute in question, and that the sole test should be injury in fact. ${ }^{63}$ Professor Jaffe, on the other hand, maintains that "a plaintiff who does not have a 'protected interest,' whether as an individual or a group, does not have a right to review, but that a court in its discretion may at the suit of such person review the legal question if it deems such consideration to be in the public interest." 64 Jaffe seems to construe the phrase "zone of interests" narrowly, for he argues that this discretion should be exercised if it appears that "those having a defined 'legal' interest do not adequately represent all of the interests intended to be protected by the legislation and if there is no device for public control" or if the court concludes that the public authorities are insufficiently responsive to the unrepresented interests. ${ }^{65}$ The requirement that the plaintiff's interest be "arguably within the zone of interests to be protected or regulated" on its face preserves some element of Jaffe's "legal interest" and may allow the discretion he advocates. If, on the other hand, the interest requirement is consistently read as broadly as its vagueness permits, the test may be reduced to Davis' sole criterion of injury in fact, which is susceptible of broad interpretation as well. ${ }^{66}$

What will limit the discretion inherent in the broad formulation of the standing test in Data Processing? The principal constraint is the article III limitation of the judicial power to cases or controversies. Requiring some personal stake-an interest or injury not shared by

$60 I d$. at 153.

61 Id. at 154.

62 See, e.g., K. Davis, supra note $23, \S \S 22.00$ to $.00-5$ (Supp. 1970) ; Comment, Judicial Review of Agency Action: The Unsettled Law of Standing, 69 MrcH. L. REv. 540 (1971) ; Note, Standing to Challenge Administrative Action: The Concept of Personal Stake, 39 GEo. Wash. L. REv. 570 (1971).

63 See K. Davis, supra note $23, \$ \$ 22.00$ to .00-5 (Supp. 1970). Davis argues that the second part of the test is faulty because (1) it limits the extension of common-law remedies; (2) it excludes plaintiffs whose interests were not to be regulated by the statute even if they were in fact regulated; (3) it is inconsistent with previous cases granting standing on the basis of injury in fact; (4) it is contrary to the congressional intent in the APA; and (5) the inquiry into legislative history it requires is cumbersome and often inconclusive. Id. $\$ 22.00-3$.

64 Jaffe, Standing Again, 84 HARv. L. Rev. 633, 634-35 (1971) (emphasis in the original).

65 Id. 637. Jaffe cites National Ass'n of Securities Dealers v. SEC, 420 F.2d 83 (D.C. Cir. 1969), vacated on other grounds sub nom. Investment Company Institute v. Camp, 401 U.S. 617 (1971), as a case where plaintiffs' legal interest was doubtful, but standing was granted because the questions were of large public interest. In this case there was no general grant of review to aggrieved parties as in Sanders, see note 53 supra \& accompanying text, and no implied intent to protect plaintiffs discernible in the legislative history, as there was in Hardin, see note 56 supra \& accompanying text.

66 See 397 U.S. at 154. 
members of the general public-is said to "assure that concrete adverseness which sharpens the presentation of the issues upon which the court so largely depends for illumination of difficult . . . questions." ${ }^{67} \mathrm{It}$ has been suggested, however, that the requirement of a peculiar personal interest is a mechanism for judicial self-restraint rather than a constitutional requirement. ${ }^{68}$ Judicial self-restraint deters courts from attempting to extend their power to reach political disputes. The prospect of increased litigation and decreased efficiency of the judicial system has been raised, but as a practical matter the actual cost of litigation tends to prevent frivolous suits, just as it tends to serve the article III requirement of case or controversy. ${ }^{69}$ There is, finally, some possibility that, if the parties whose interests lie on the periphery of the "zone" or whose "injury in fact" is very slight, were granted standing, they might use the delay accompanying judicial review to coerce those whose interests were more central. ${ }^{70}$ None of these potential limitations, however, compels a narrow reading of the Data Processing holding.

If personal involvement in the outcome is indeed required by the Constitution, it may be a very small one in economic terms, ${ }^{71}$ or even an ideological stake difficult to ascribe to a particular person or group. ${ }^{\mathbf{2}}$ Indeed, in Scenic Hudson Preservation Conference v. FPC ${ }^{73}$ and Office of Communication of the United Church of Christ v. FCC, ${ }^{74}$ it is difficult to discern how the plaintiffs had any more interest in aesthetics, conservation, and recreation, or in the prevention of racial and religious bias in television programming, than members of the public at large, other than the fact that they had chosen to band together, at great cost, to articulate those interests. ${ }^{75}$ These cases, cited by the Court in Data Processing as examples of the "injury" required by the test, ${ }^{76}$ suggest that the injury need not distinguish the plaintiff from members of the public at large.

67 Baker v. Carr, 369 U.S. 186, 204 (1962). If "concrete adverseness" lies at the heart of the requirement, is not such adverseness demonstrated by willingness to bear the cost of litigation? See Jaffe, The Citizen as Litigant in Public Actions: The Non-Hohfeldian or Ideological Plaintiff, 116 U. PA. L. REv. 1033, 1037-38 (1968).

68 See Berger, Standing to Sue in Public Actions: Is It a Constitutional Requirement?, 78 YALE L.J. 816 (1969) ; Note, The Essence of Standing: The Basis of a Constitutional Right to be Heard, 10 ARIZ. L. REv. 438 (1968); cf. Flast v. Cohen, 392 U.S. 83, 93-94 (1968).

69 See Office of Communication of the United Church of Christ v. FCC, 359 F.2d 994, 1006 (D.C. Cir. 1966); Davis, Standing: Taxpayers and Others, 35 U. CHr. L. Rev. 601, 634 (1968) ; cf. Flast v. Cohen, 392 U.S. 83, 94 (1968).

$70 \mathrm{Cf}$. notes 873-81 infra \& accompanying text.

71 See Davis, supra note 69.

72 See, e.g., Allen v. Hickel, 424 F.2d 944 (D.C. Cir. 1970) (standing to seek injunction against construction of Nativity scene in federal park conferred by plaintiffs' interest in establishment clause and free-exercise clause).

73354 F.2d 608 (2d Cir. 1965), cert. denied, 384 U.S. 941 (1966).

74359 F.2d 994 (D.C. Cir. 1966).

75 See Jaffe, supra note 67. But see Sierra Club v. Hickel, 433 F.2d 24, 30 (9th Cir. 1970), aff'd sub nom. Sierra Club v. Morton, 40 U.S.L.W. 4397 (U.S. Apr. 19, 1972); Note, supra note 62 , at $588-91$.

76 See 397 U.S. at 154. 
The extent to which the law of standing has consequently expanded, so that any concerned citizen or group can be considered "aggrieved" within the meaning of section 10 of the APA, is, however, still unclear. In Citizens Committee for the Hudson Valley v. Volpe, ${ }^{77}$ the Second Circuit determined that a resident citizens group and a national conservation organization that were concerned with the beauty of the Hudson River Valley had standing to contest the issuance of a dredge and fill permit by the Army Corps of Engineers to the State of New York for the construction of a proposed highway.

\begin{abstract}
Two of the plaintiffs (the Citizens Committee and the Sierra Club) made no claim that the proposed Expressway or the issuance of the dredge and fill permit threatened any direct personal or economic harm to them. Instead they asserted the interest of the public in the natural resources, scenic beauty and historical value of the area immediately threatened with drastic alteration, claiming that they were "aggrieved" when the Corps acted adversely to the public interest. ${ }^{78}$
\end{abstract}

The groups "evidenced the seriousness of their concern with local natural resources by organizing for the purpose of cogently expressing it, and the intensity of their concern is apparent from the considerable expense and effort they have undertaken in order to protect the public interest which they believe is threatened . . ." 79 The court held that standing "as responsible representatives of the public" was afforded by the public interest in environmental resources recognized by several federal statutes. ${ }^{80}$

The Supreme Court, however, has recently rejected the Hudson $V$ alley approach, holding instead that 'a mere 'interest in a problem,' no matter how qualified the organization is in evaluating the problem, is not sufficient by itself to render the organization 'adversely affected' or 'aggrieved' within the meaning of the APA," in Sierra Club v. Morton. The Court felt that the "requirement that a party seeking review must allege facts showing that he is himself adversely affected" would "serve as at least a rough attempt to put the decision as to whether review will be sought in the hands of those who have a direct

77425 F.2d 97 (2d Cir.), cert. denied, 400 U.S. 949 (1970).

$78 \mathrm{Id}$. at 102.

$79 \mathrm{Id}$. at 103.

80 See id. at 104-05.

8140 U.S.L.W. 4397, 4401 (U.S. Apr. 19, 1972), aff'g Sierra Club v. Hickel, 433 F.2d 24 (9th Cir. 1970). Petitioner Sierra Club had sought declaratory and injunctive relief against the issuance by the United States Forest Service of permits for a " $\$ 35$ million complex of motels, restaurants, swimming pools, parking lots, and other structures [including "ski lifts, ski trails, a cog-assisted railway, and utility installations'] designed to accommodate 14,000 visitors daily," and against the approval by the Department of the Interior of a 20 -mile highway and a high-voltage power line to serve the complex. 40 U.S.L.W. at 4398. The focus of these developments was to be the Mineral King Valley, "an area of great natural beauty nestled in the Sierra Nevada Mountains . . . adjacent to Sequoia National Park." Id. 
stake in the outcome." 82 It seems obvious, however, that, on the facts presented, there was no significant difference between the "interest" alleged by the organization and the "interests" of its members who used the affected area for recreational purposes, and this fact seems implicit in the dissenting opinions. Justice Douglas suggested that

[ $t$ ] he critical question of "standing" would be simplified and also put neatly in focus if we fashioned a federal rule that allowed environmental issues to be litigated before federal agencies or federal courts in the name of the inanimate object to be dispoiled, defaced, or invaded by roads and bulldozers and where injury is the subject of public outrage. Contemporary public concern for protecting nature's ecological equilibrium should lead to the conferral of standing upon environmental objects to sue for their own preservation. ${ }^{83}$

And, in his thoughtful dissent, Justice Blackmun pronounced Douglas's approach imaginative, and presented the following argument, which speaks for itself:

. . I would permit an imaginative expansion of our traditional concepts of standing in order to enable an organization such as the Sierra Club, possessed, as it is, of pertinent, bona fide and well-recognized attributes and purposes in the area of environment, to litigate environmental issues. . . . We need not fear that Pandora's box will be opened or that

8240 U.S.L.W. at 4401 . The Court noted that

[ $t$ ] he Club apparently regarded any allegations of individualized injury as superfluous, on the theory that this was a "public" action involving questions as to the use of natural resources, and that the Club's longstanding concern with and expertise in such matters were sufficient to give it standing as a "representative of the public."

Id. at 4400 (footnote omitted). The Court found the following statement of the club's "interest" in the original pleadings inadequate:

Plaintiff Sierra Club is a non-profit corporation organized and operating under the laws of the State of California, with its principal place of business in San Francisco, California since 1892. Membership of the Club is approximately 78,000 nationally, with approximately 27,000 members residing in the San Francisco Bay area. For many years the Sierra Club by its activities and conduct has exhibited a special interest in the conservation and sound maintenance of the national parks, game refuges and forests of the country, regularly serving as a responsible representative of persons similarly interested. One of the principal purposes of the Sierra Club is to protect and conserve the national resources of the Sierra Nevada Mountains. Its interests would be vitally affected by the acts hereinafter described and would be aggrieved by those acts of the defendants as hereinafter more fully appears.

Id. at $4400 \mathrm{n} .8$. The club could have easily relied upon individual interests of its members, such as the fact that "various members of the Club have used and continue to use the area for recreational purposes"; and the Court noted that its decision did not bar the club from seeking to amend its complaint accordingly. Id. The lapse of time, however, makes obtaining the relief originally sought much more difficult, as Justice Blackmun pointed out in his dissent. Id. at 4406.

$83 \mathrm{Id}$. at 4402 (footnote omitted). Justice Douglas relied in part on arguments contained in Stone, Should Trees Have Standing? Toward Legal Rights for Natural Objects, 45 S. CAL. L. REV. 450 (1972). 
there will be no limit to the number of those who desire to participate in environmental litigation. The courts will exercise appropriate restraints just as they have exercised them in the past. Who would have suspected 20 years ago that the concepts of standing enunciated in Data Processing and Barlow would be the measure for today? ${ }^{84}$

The effect of Data Processing on intervention in agency proceedings is not yet clear. Section 6(a) of the APA provides:

A party is entitled to appear in person or by or with counsel or other duly qualified representative in an agency proceeding. So far as the orderly conduct of public business permits, an interested person may appear before an agency or its responsible employees for the presentation, adjustment, or determination of an issue, request, or controversy in a proceeding, whether interlocutory, summary, or otherwise, or in connection with an agency function. ${ }^{85}$

This section gives the agency discretion in the first instance to determine when, where, and how an "interested person may appear." It does not in terms define what interest a person or party must demonstrate or what form an interested person's or party's participation is to take. The organic statutes are, with few exceptions, ${ }^{86}$ equally. vague as to what kind of interest entitles one to participate and what form such participation may take. Definition is usually left to the agency, subject to judicial review. The judicial power to construe an agency's statutory mandate, and to review its determination of the interests that must be considered thereunder and of the procedural rights that must be accorded those representing such interests, constitutes perhaps the most powerful check on administrative action. This power has been utilized to expand the definition of those interests that must be allowed to intervene and the scope of that intervention. ${ }^{87}$

The two United Church of Christ appeals ${ }^{88}$ reveal perhaps the furthest incursion by a court into an agency's discretion to shape its intervention policy. ${ }^{89}$ The court, rejecting the assumption that an agency always represents the totality of the public interest, ${ }^{90}$ initially held that members of the listening public were entitled to intervene

8440 U.S.L.W. at $4406-07$.

855 U.S.C. $\$ 555$ (b) (1970).

86 See, e.g., notes 732-35 infra \& accompanying text.

87 Cf. notes 57-84 supra \& accompanying text.

88 See notes 363-76, 426-36 infra \& accompanying text.

89 Cf. Note, Expansion of "Public Interest" Standing, 45 N.C.L. Rev. 998 (1967). 90 See note 373 infra \& accompanying text. 
before the FCC ${ }^{91}$ and later expressed profound dissatisfaction with the form of participation granted the intervenors. ${ }^{92}$

The two United Church of Christ appeals were precursors to the broad test established in Data Processing. ${ }^{93}$ How that test will influence standing to intervene in agency proceedings was discussed, if not resolved, in National Welfare Rights Organization v. Finch. ${ }^{94}$ That case first confronted a problem involved in standing to obtain judicial review which also arises in the FPC and FTC: ${ }^{95}$ whether a statutory grant of standing to obtain review to one class implies denial of standing to other classes. In Welfare Rights, the question was whether a specific grant of standing to states to seek review of determinations whether their laws were in conformity with the Social Security Act, implied that welfare recipients did not have a similar right. Judge Wright noted that, although the statutory scheme spoke "only of the functions of the Secretary and the rights of the state to a hearing and judicial review," ${ }^{96}$ such review should not be denied welfare recipients, who otherwise met the Data Processing test, ${ }^{97}$ absent a clear showing that Congress intended to deny such review. Finding "that Congress gave the states standing in order to strengthen federalism," 98 the court declared that "it is not contrary to that purpose that welfare recipients also have standing to seek review." 99

One serious problem remained. Unlike the organic acts of the agencies considered in this Comment which make some general provision for intervention, the Social Security Act is silent as to whether participation in the prehearing negotiations and the formal conformity hearings was limited exclusively to the Department of Health, Education, and Welfare and to the states affected, ${ }^{100}$ though HEW's practice apparently was to permit, in its discretion, some limited forms of thirdparty participation in the hearings. ${ }^{101}$ The court noted that "specific statutory provisions explicitly controlling intervention are exceptional when viewed in the context of all legislative enactments pertaining to administrative proceedings" and that such provisions perhaps "represent special recognition by Congress of a need to have interested parties

91 See notes 374-76 infra \& accompanying text.

92 See notes 431-36 infra \& accompanying text.

93 See notes 53-84 supra \& accompanying text.

94429 F.2d 725 (D.C. Cir. 1970). See Comment, Intervention in HEW Welfare Conformity Proceedings, 6 HARv. CIV. RigHTs-CIV. LrB. L. REv. 559 (1971).

95 See notes 682-706 (FTC), 746-47, 768-74 (FPC) infra \& accompanying text.

96429 F.2d at 732.

97 Id. at 735 .

98 Id. at 736 .

99 Id. (emphasis in the original). The Ninth Circuit recently reached a contrary conclusion in an analogous statutory context. See Rasmusson v. Hardin, 40 U.S.L.W. 2674 (9th Cir., Mar. 29, 1972).

100 See id. at 731-32.

101 See id. at 731 n.21. 
involved in agency proceedings to protect the public interest." 102 As a general rule, however, the court felt that "[e]xcept for the adjustments necessary for assuring the manageability of administrative proceedings, the criteria for standing for review of agency action appear to assimilate the criteria for standing to intervene." 103

Although the court did not explicitly equate standing to obtain review with standing to intervene, it held, on the facts presented, that the "right of judicial review cannot be taken as fully realized . . . , if appellants are excluded from participating in the proceeding to be reviewed." 104 Under the circumstances presented in Welfare Rights, and especially in light of the statutory provision that the Secretary's findings of fact should be conclusive if supported by substantial evidence, ${ }^{105}$ the court felt that important issues might be foreclosed on review and that a full consideration of the competing interests would only be possible through appellants' "full participation in the initial agency hearing." ${ }^{106}$ The statutory provision for remanding to the agency with instructions to take further evidence was not sufficient to cure the deficiency. ${ }^{107}$ The court felt that participation in the conformity hearing would help avoid a multiplicity of suits ${ }^{108}$ and recognized that the expense of participation would limit any great influx of welfare recipients into the hearings. ${ }^{109}$ The court approved limiting intervention to groups which seem best able to represent the common interests of welfare recipients. ${ }^{110}$ Most important, the court stated that it contemplated enlargement of the participation already allowed such groups ${ }^{111}$ "only to the extent of an additional right to present live

102 Id. at 732 (footnotes omitted).

103 Id. at 732-33. The court did not reach NWRO's claim that it had a constitutional due process right to intervene. 420 F.2d at 734 n.33. See Comment, supra note 94 , at $569-71$.

104 Id. at 736. The court relied primarily on the reasoning of American Communications Ass'n v. United States, 298 F.2d 648 (2d Cir. 1962), and of Judge Sobeloff's dissent in First Nat'l Bank v. Saxon, 352 F.2d 267 (4th 'Cir. 1965). In the latter case, the majority held that the Comptroller of Currency could authorize establishment of a branch of a national bank without first affording a hearing, even though a competitor had a right to judicial review of that decision. $C f$. Freedman, Administrative Procedure and the Control of Foreign Direct Investment, 119 U. PA. L. Rev. 1, 70-71 (1970). In Data Processing, the Supreme Court did not consider whether plaintiff had a right to a hearing before the Comptroller prior to the issuance of regulations that might affect its interest. Association of Data Processing Serv. Organizations v. Camp, 397 U.S. 150 (1970).

105429 F.2d at 737.

$108 \mathrm{Id}$.

107 Id. The likelihood in many cases that only a hearing will cure an erroneous denial of intervention strengthens the argument that denial should be immediately appealable to the full agency and thereafter to the court of appeals. See Note, Intervention by Third Parties in Federal Administrative Praceedings, 42 NoTRE DAME LAw. 71, 76-77 (1966).

108429 F.2d at 738 .

$109 \mathrm{Id}$. at $738-39$.

110 Id. at 739 ; cf. notes $374-76$ infra \& accompanying text. Thus, an individual welfare recipient might properly be denied intervention in favor of the National Welfare Rights Organization and its state counterpart.

111 See note 101 supra \& accompanying text. 
witnesses and to cross-examine witnesses for other parties," 112 that these groups were not entitled to participate in informal negotiations between HEW and the states, and that the Secretary's right to terminate a hearing upon his determination that conformity had been reached would be unaffected. The court further emphasized that the problems of extended cross-examination and introduction of testimony irrelevant to the issues before the agency should be controlled by the hearing examiner. ${ }^{113}$

Welfare Rights, then, is a good summary of the law-and the confusion-regarding the relationship between standing to obtain review and standing to intervene. In cases where a hearing is held, groups meeting the Data Processing test for review have standing to intervene to the extent necessary to make the right of review effective. Having established that principle, the court in Welfare Rights proceeded to define the procedural rights that would make the right of review effective under the circumstances presented, carefully preserving to the agency the power to limit intervention to particularly representative groups, to exclude repetitive or irrelevant testimony, and to exclude intervenors from private informal negotiations. The court established no precise formula from which the nature and extent of an intervenor's procedural rights may be derived.

Because the problems of intervention before courts and agencies are frequently similar, an examination of rule 24 of the Federal Rules of Civil Procedure and its shortcomings may reveal some principles equally applicable to agencies. ${ }^{114}$ To the extent that a group would have standing under the Data Processing test to initiate review of agency action, it would seem, at first blush, that it should be allowed to intervene in review initiated by another. Rule 24 , however, seems

112429 F.2d at 739.

113 Id. at 739 n. 46 .

114 There are of course considerations which are unique to intervention before courts. A prospective intervenor may be bound by the judgment; he may have a related claim or defense which might be prejudiced if he were not allowed to intervene, or which might avoid duplication, delay, or inconsistent results if tried with the original case. In diversity cases, he would have to meet jurisdictional requirements. See Shapiro, supra note 37, at 731-34. Given the limited scope of review, see notes $135-55$ infra \& accompanying text, and the concern it reflects that courts should not, indeed cannot, perform the tasks of the agency de novo on appeal; perhaps the only inquiries of the court should be whether the interest of the party attacking the agency decision should have been considered by the agency and in fact wac not, and whether there was substantial evidence in favor of other interests. Tric limited scope of judicial inquiry might thus reduce the need for full renresentation of all parties appearing before the commission, though the need obviously varies with the nature of the agency action under review. Cormpure Calvert Cliffs' Coordinating Comm. v. AEC, 449 F.2d 1109 (D.C. Cir. 1971), in which the central questionwhether the essentially procedural rules promulgated by the AEC fully complied with the purpose of the National Environmental Policy Act of $1969 \$ 102(2), 42$ U.S.C. $\$ 4332(2)(1970)$-could arguably have been decided without extensive participation by power companies (although in fact one company did intervene and several others filed briefs as amici), with Scenic Hudson Preservation Conference y. FPC, 453 F.2d 463 (2d Cir. 1971), in which resolution of the complicated factual issues involved in the court's review of the record was arguably facilitated by extensive participation by third parties. 
considerably more restrictive. ${ }^{115}$ Professor Shapiro has criticized the present rule on the ground that intervention as of right under rule 24(a) may be granted too freely to certain intervenors ${ }^{116}$ while the scope of permissive intervention under rule $24(\mathrm{~b})$ is too limited, and restricts the scope of intervention by public interest groups or "private attorneys general." $117 \mathrm{He}$ has proposed a functional approach to permissive intervention which would consider

(1) the nature and extent of the applicant's interest in the subject matter of the action and the degree to which the disposition of the action may as a practical matter impair or impede his ability to protect that interest; (2) the adequacy of representation of the applicant's interest by existing parties; (3) the relationship of the applicant's claim or defense, if any, to the subject matter of the action; (4) the avoidance of multiplicity of actions; (5) whether the intervention will unduly delay or prejudice the adjudication of the rights of the original parties; and (6) the contribution the applicant may make to the just determination of the issues. ${ }^{118}$

Shapiro would also give the court wide discretion to limit the scope of permissive intervention and intervention as of right, and would make denial of either immediately appealable. ${ }^{119}$ An appeal would not stay proceedings unless so ordered by a court. ${ }^{120}$ Under the present rule 24 (a), the fact that the potential intervenor's interest is adequately represented by existing parties is a ground for denying intervention altogether; Shapiro's proposal might permit informal or limited intervention as an alternative to outright denial. It seems clear, however, that under either, meeting the Data Processing test alone does not automatically confer a right to intervene in a court proceeding, or, as $W e l$ fare Rights indicates, in an administrative proceeding.

115 FED. R. CIv. P. 24 :

(a) Intervention of Right. Upon timely application anyone shall be permitted to intervene in an action: (1) when a statute of the United States confers an unconditional right to intervene; or (2) when the applicant claims an interest relating to the property or transaction which is the subject of the action and he is so situated that the disposition of the action may as a practical matter impair or impede his ability to protect that interest, unless the applicant's interest is adequately represented by existing parties.

(b) Permissive Intervention. Upon timely application anyone may be permitted to intervene in an action: (1) when a statute of the United States confers a conditional right to intervene; or (2) when an applicant's claim or defense and the main action have a question of law or fact in common . . . In exercising its discretion the court shall consider whether the intervention will unduly delay or prejudice the adjudication of the rights of the original parties. text.

116 See Shapiro, supra note 37 , at 757-59; cf. notes 625-40 infra \& accompanying

117 See Shapiro, supra note 37 , at 758.

118 Id. at 762 .

119 Id.

$120 I d$. at 762-63. 


\section{Pursuing "The Public Interest"}

\section{The Decisionmaking Model}

The agencies here considered are charged to act in accordance with the public interest. ${ }^{121}$ This bare mandate is vague; at times, it is misleading. Criticisms of current agency practice and attempts to define the public interest in the administrative context have largely focused upon devising procedures whereby "better" decisions may be derived, rather than dictating the substantive norms that are most "in the public interest" in specific contexts. .Charles Reich, for example, argues that the federal agencies, apparently defining the term "public interest" to mean the harmonious balancing of as many of the competing or conflicting interests as possible in a specific factual context, ${ }^{122}$ contribute to the "central myth . . . that decisions concerning planning and allocation can be, and are, made on an objective basis." 123 Adjudicatory procedure enhances the myth, by giving the impression that value choices-"what kind of television programs Boston should have," for example - can be decided before agencies, as issues of fact are tried to courts of law. ${ }^{124}$ The adjudicative process, with its ad hoc, passive mediation of the powerful private economic interests which customarily present themselves before it, according to rules of procedure which tend to foreclose consideration of unargued alternatives or attention to unrepresented interests, inhibits the independent formation of general policies. ${ }^{125}$ Reich views the administrative process as fundamentally conservative and responsive only to immediate pressures. ${ }^{126}$ He urges that it has a responsibility for wide-ranging, independent, innovative planning, which can be fulfilled in part by a broader definition of the issues each agency must consider and by a much broader spectrum of information upon which to base its value choices.

Reich implies a proposition that needs to be articulated more precisely and forcefully. In a highly pluralistic society such as ours, it is almost impossible to say that there is a unitary public interest or that any proposed action is a priori in the public interest. ${ }^{12 \pi}$ Apart from

121 See, e.g., 47 U.S.C. $\$ 303$ (1970) (FCC).

122 Reich, supra note 16 , at 1234 .

123 Id. 1235.

124 Id. Some early theorists, and especially Max Weber, viewed the purpose of the administrative process as the expert formulation of a system of rules, based upon general principles implicit in the social structure or defined by the legislative branch, to be applied to specific cases. See, e.g., G. Berkiex, The Administrative Revolurron 8-9 (1971). The neutral development and application of a national policy might, under this view, be impeded if an agency were to respond to sectional interest groups.

125 Reich, supra note 16, at 1238-39.

126 Id. 1239.

127 The only arguably neutral criterion of the public interest would seem to be whether a perfectly generalizable effect felt by all citizens is "helpful" or "harmful." Assume that the lives of citizens of a country must be preserved. Universal distribution of a vaccine needed to forestall an epidemic is in the public interest, while 
the obvious minimal function of the term as a symbol or "facade for special interests and partisan position in the political battle" ${ }^{128}$ and the tautology that the public interest is what the agency charged to act in the public interest defines it to be, there seem to be three views of decisionmaking in the public interest-those Glendon Schubert calls "rationalist," "idealist," and "realist"-which have served as bases for models of the administrative process:

The rationalists .. . envisage a political system in which the norms are all given . . . and the function of political and bureaucratic officials alike is to translate the given norms into specific rules of governmental action. The idealists . . . conceive of the decision-making situation as requiring the exercise of authority to engage in social planning by clarifying a vague criterion. The realists . . . state that the function of public officials is to engage in political mediation of disputes; the goals of public policy are specific but in conflict. $^{129}$

Schubert characterizes rationalists as "propublic, proparty, and anti-interest group." They believe in the "popular will," which they determine either through the outcome of the contests of a strong twoparty system or directly by consulting public opinion. "In both instances, administrators and judges are supposed to exercise technical discretion [discretion to define the means but not the goal] to carry out norms which they do not make, but which are supplied to them in the form of constitutional provisions, statutes, and executive orders." 130

Idealists are "propublic, antiparty, and anti-interest group." They conceive of the public interest in terms of a substantive natural law, which may or may not be perceived by the public itself, and are only in that sense "propublic." The public interest "is what the elite thinks is good for the masses," and the administrative process entails

turning the country's military forces on the civilian population, even to preserve the stability of a country's political structure, is not. But such unitary imperatives are rare in modern pluralistic societies, as are effects as generalizable as those of plague and civil war. Theorists, such as Jeremy Bentham, who posit the public interest to be the sum of all private interests (the latter being widely defined to include aesthetic, moral, and kindred interests of individuals, as well as the more traditional "legal" interests such as a contractual right) find it difficult to explain the source of decisionmaking criteria applied by an administrative body to achieve a balance in a particular case. See J. Bentham, A Fragment on Government and Princtples and Morals OF LEGISLATION 126 (1 vol. ed. 1948); note 122 supra \& accompanying text. See generaliy Nomos V: The Public Interest (C. Friedrich ed. 1962) [hereinafter cited as Nomos V].

128 Friedrich, Preface to Nomos V, supra note 127, at vii.

129 Schubert, Is There a Public Interest Theory?, in Nomos V, supra note 127, at 164. See also Schubert, "The Public Interest" in Administrative Decision Making: Theorem, Theosophy, or Theory?, 51 AM. PoL. Scr. REv. 346 (1957).

130 Schubert, Is There a Public Interest Theory?, in Nomos V, supra note 127, at $164-66$ 
primarily "the exercise of craft and conscience" 131 to achieve the administrator's perception of that good.

Realists are prointerest group, and tend to view both parties and the general public in terms of their constituent groups. They view decisionmaking as (1) responding to pressures actually exerted upon them by groups, (2) responding to interests that they perceive, but which are not actively pressed upon them, in addition to those pressures actually exerted, or (3) independently determining goals based upon what they conceive to be an ideal balancing of the interests and pressures they perceive. This third variant differs from the idealist view only in that these realists make an effort to ascertain the desires and needs of the interest groups they perceive, and hence this variant is less inherently conservative than the first, which looks to existing pressures and their relative strengths, thereby favoring the status quo.

Schubert associates these realist attitudes toward the administrative process with what he calls the due-process-equilibrium model. Its basic principle is that "decisions reached as a result of . . . full consideration [of all available relevant information, including, in appropriate contexts, opinion] are more likely to meet the test of equilibrium theory-i.e., 'satisfaction,' acceptance, and the like-and do so most of the time . . . ." 132 Decisions in the public interest result from the application of proper procedures. Thus, the model concentrates on decisions that are "acceptable," rather than decisions that are "right" in an abstract sense: the emphasis is on procedures more than on underlying norms or values.

The due-process-equilibrium model of administrative decisionmaking, and the definition of the public interest derived therefrom, seem the most workable. There is, of course, no way this highly abstract model can be proved "correct" or "incorrect"; perhaps the only relevant questions about it are whether it has an internal logic, whether it makes provision for all relevant variables, and-since it is, after all, an idealwhether it seems reflected in the thinking of people with practical experience in the area. ${ }^{133}$

131 Id. $166-67$.

132 Id. 170-71.

133 Reich, under this analysis, initially seems part idealist, part realist. He seems an idealist in that he wants the agencies to exercise broad planning powers insulated from immediate pressures. His more specific proposals-broader sets of criteria for the agencies to consider, increased public participation in agency proceedings, advisory hearings, institutionalized representation of previousiy unrepresented interests-seem those of a realist intent on improving a basically sound system. His view of decisionmaking, then, is probably closer to the third realist variant. Similarly, FCC Commissioner Johnson's suggestions go to improving FCC procedure by insulating the Commission from unduly concentrated influence by any particular interest, by increasing the informational inputs through encouragement of participation, by improving its investigatory facilities, by obtaining as many "expert" points of view as possible before making wide-ranging policy decisions, and by reducing regulatory delay. See generally Johnson, supra note 17. His suggestions, like Reich's, imply an assumption that the due-process-equilibrium model will be viable if the process afforded is fair, that is, if all interests affected by a decision are allowed to present information (in- 
The source of the decisionmaker's values is the central problem of this model. Because it draws on the judicial model, it assumes certain judicial qualities in the decisionmaker, most notably a degree of impartiality toward or insulation from the parties before him. But the model also contemplates that agency independence and expertise will prevent the decisionmaker from being too much bound by precedent. It invests him with more discretion, not always exercised, to formulate policy than his judicial counterpart: he is free, to some extent, to choose his own values. This problem is especially characteristic of the third variant of realist decisionmaking.

Ultimately, Congress and the courts retain great power to dictate values to agency decisionmakers, a power which may be more frequently exercised in the future. Congress, in supplying only the bare mandate to act in the public interest, has not historically concerned itself with providing specific values for decisionmakers. Recently, however, popular concern over environmental damage has led Congress to attempt to provide a more specific value in this area. The National Environmental Policy Act (NEPA) ${ }^{134}$ purports to force decisionmakers to include among their values a concern for preventing further damage to the environment. The resistance that has met the NEPA leads one to doubt that values can be effectively imposed in this broad manner. With the exceptions of radical restructuring of the agencies, and of informal mechanisms of control exercised by Congress and the President (such as budget allocations and appointment of personnel), case-by-case examination by the courts may provide the only effective review of agency value choices.

Traditionally, the courts have been reluctant to impose values upon agency decisionmakers. They have, for example, found agency implementation of the NEPA deficient in several instances. ${ }^{135}$ But, because of largely self-imposed limitations upon their own power to review administrative decisions and thereby substitute their own judgment, courts have at most demanded strict adherence to procedure, ${ }^{136}$ or strict con-

cluding, where appropriate, opinion) to the decisionmaker. Former FTC Commissioner Elman seems more the rationalist in that he would increase the accountability of the Commission to the President and Congress. He is, however, dealing with an agency enforcing vague statutory prohibitions, and he does concede that the FTC's rulemaking processes should be decentralized and opened to more points of view. See note 583 infra.

13442 U.S.C. $\$ \S 4321-47$ (1970).

135 See, e.g., Calvert Cliffs' Coordinating Comm. v. AEC, 449 F.2d 1109 (D.C. Cir. 1971) ; Committee for Nuclear Responsibility v. Seaborg, No. 71-1732 (D.C. Cir., Oct. 5, 1971). For accounts of the effect of the NEPA in increasing the number of issues the agency must consider, or in increasing agency responsibility to explore alternative modes of action, see notes 800-03, 901-13 infra \& accompanying text.

136 "Section 102 of NEPA requires, inter alia, that an impact statement assess adverse environmental effects and discuss alternatives to the proposed action. On the ultimate issue whether a project should be undertaken or not, a matter involving the assessment and weighing of various factors, the court's function is limited. However, the court has a responsibility to determine whether the agencies involved have fully and in good faith followed the procedure contemplated by Congress . . ." Committee for Nuclear Responsibility v. Seaborg, No. 71-1732, at 5-6 (D.C. Cir., Oct. 5, 1971) (footnote omitted). 
struction of an agency's statutory authority. ${ }^{137}$ What prevents courts from going further? The APA provision for review is, on its face, quite broad. ${ }^{138}$ Unless otherwise provided by law, questions of "law" are for the courts, questions of "fact" for the agency, reviewable by the courts only when "unsupported by substantial evidence," 139 or lacking a rational basis. ${ }^{140}$ Professor Jaffe defines a finding of fact as "the assertion that a phenomenon has happened or is or will be happening independent of or anterior to any assertion as to its legal effect." ${ }^{141}$ If this test were strictly applied, there would be little agency decisionmaking that could withstand characterization as questions of law or mixed questions of law and fact, both of which are within a court's competence to decide. ${ }^{142}$ Jaffe argues that, even though many agency decisions are not findings of fact under his definition, "the legislature in realizing its [statutory] purposes has chosen to work through an administrative agency, and so (presumptively, as we have said) to

137 See, e.g., Citizens Comm. for the Fudson Valley v. Volpe, 302 F. Supp. 1083 (S.D.N.Y. 1969), aff'd, 425 F.2d 97 (2d Cir.), cert. denied, 400 U.S. 949 (1970) (construction of expressway enjoined because part of structure was a "dike" which required specific congressional approval under the statute).

138 Administrative Procedure Act $\$ 10(e), 5$ U.S.C. $\$ 706$ (1970) :

To the extent necessary to decision and when presented, the reviewing court shall decide all relevant questions of law, interpret constitutional and statutory provisions, and determine the meaning or applicability of the terms of an agency action. The reviewing court shall-

(1) compel agency action unlawfully withheld or unreasonably denied; and

(2) hold unlawful and set aside agency action, findings, and conclusions found to be-

(A) arbitrary, capricious, an abuse of discretion, or otherwise not in accordance with law;

(B) contrary to constitutional right, power, privilege, or immunity;

(C) in excess of statutory jurisdiction, authority, or limitations, or short of statutory right;

(D) without observance of procedure required by law;

(E) unsupported by substantial evidence in a case subject to sections 556 and 557 of this title or otherwise reviewed on the record of an agency hearing provided by statute; or

(F) unwarranted by the facts to the extent that the facts are subject to trial de novo by the reviewing court.

In making the foregoing determinations, the court shall review the whole record or those parts of it cited by a party, and due account shall be taken of the rule of prejudicial error.

There are, of course, instances where this standard is made inapplicable to agency action by, for example, a more restrictive statutory provision for review. See generally $4 \mathrm{~K}$. DAVIs, supra note $23, \S \S 28.09-.16$.

1395 U.S.C. $\$ 706(2)$ (E) (1970).

140 See $4 \mathrm{~K}$. Davis, silpra note $23, \$ 30.05$.

141 L. JAFFE, supra note 33, at 548 (emphasis omitted).

142 Very rarely is a finding purely a finding of fact under Jaffe's formulation; only in instances where Congress has provided a very specific definition of the public interest in a given context (for example, a prohibition against certain concentrations of pollutants in smoke emissions and a specification of a penalty) could an agency determination (for example, that there had been a violation of the prohibition) be considered purely a finding of fact. 
confer on it some policy-making function," and that "[ $t]$ his discretion should normally be permitted to function short of the point where the court is convinced that the purpose of the statute is contradicted." 143 Congress in providing its characteristically broad mandates to the agencies and equally broad standards of judicial review, has left it to the agencies in the first instance to determine many norms, and to the courts to determine at least the outer limits of agency discretion in this regard. If the courts were to attempt to usurp the value-determining functions of the agencies totally, Congress might respond by delimiting much more specifically and narrowly the review or the courts' jurisdiction. ${ }^{144}$

Judicial unwillingness to decide mixed questions of law and fact may rest on considerations less compelling than the ultimate power of Congress to restrict review to so-called constitutional and jurisdictional facts. ${ }^{145}$ Professor Davis argues that "in numerous cases the Supreme Court has customarily classified questions of application-so-called 'mixed' questions of law and fact-as questions of 'fact' whenever it has seen fit to limit review; in other words, the Court has often used a practical or policy approach to the law-fact distinction and has often rejected the literal or analytical approach." 146 Lower federal courts are presumably even more likely to make result-oriented characterizations of questions as "legal" or "factual." Davis explores at length the reasons which might lead a court to make one characterization or the other. The main reason for not substituting judgment is a court's feeling that the question or value choice is "peculiarly within the agency's competence and not especially within the competence of the reviewing court." ${ }^{147}$ In cases where judicial judgment has been sub-

143 I. JAFFE, supra note 33 , at 573 (emphasis in original). Jaffe does not deny that courts retain the power to review such decisions: "[t]he judgment of the expert may . : - be relevant to the decision, but it cannot by reason of its 'pure' quality, its specifically expert character, transform a question of law into a question of fact and so insulate the decision from legal judgment." Jaffe, Judicial Review: Question of Law, 69 Harv. L. REv. 239, 269 (1955). (1970):

${ }^{144}$ Cf. Military Selective Service Act of 1967, 50 U.S.C. App. $\$ 460$ (b) (3)

No judicial review shall be made of the classification of or processing of any registrant by local boards, appeal boards, or the President, except as a defense to a criminal prosecution instituted under [50 U.S.C. App. § 462], after the registrant has responded either affirmatively or negatively to an order to report for induction ...: Provided, That such review shall go to the question of the jurisdiction herein reserved to local boards, appeal boards, and the President only when there is no basis in fact for the classification assigned to such registrant.

See generally H.M. Hart \& H. Wechsler, The Federal Courts and the Federad SysteM 312-40 (1953).

145 See Jaffe, Judicial Review: Constitutional and Jurisdictional Fact, 70 HaRv. L. Rev. 953 (1957).

$1464 \mathrm{~K}$. Davis, supra note $23, \S 30.01$, at 190.

147 Id. 191. In the environmental area, at least, some commentators feel the only effective means of vindicating the public interest is by widening radically the scope of judicial review so that courts may reach the merits. See, e.g., J. SAx, DeFENDING THE ENVIRONMENT 108-74 (1971) ; Sive, Some Thoughts of an Environ- 
stituted, the reasons for the substitution usually are not, and, Davis suggests, "probably ought not to be articulated." 148 The judge may be familiar with an agency and trust-or distrust ${ }^{149}$-it; he may sense injustice in a particular case which might lead to a closer examination of the record and occasionally to a decision on the merits; he may be unfamiliar with the technology, or the case may appear to be sui generis and the complaining party's grievance unappealing, and he may conclude that there are other cases more deserving of attention; he may disagree with the underlying policy he perceives in a decision; ${ }^{150}$ he may feel the agency should be left alone while it explores an undeveloped area within its policymaking competence; or he may be influenced by a number of other factors. ${ }^{151}$

Courts, then, have the power to substitute their judgment for the agency's in making value choices. They have not, however, done so in most of the cases considered in this Comment; ${ }^{152}$ rather, they have used less drastic means calculated not to deprive the agencies of their power to generate policy but to influence its exercise indirectly. ${ }^{153}$ A court's decision requiring of an agency the most scrupulous adherence to procedure and liberally construing provisions investing the agency discretion to grant procedural privileges may of course suggest to the agency that it alter its decision on the merits lest the court be moved to reverse on a subsequent appeal. ${ }^{154}$ A court may believe the agency has inad-

mental Lawyer in the Wilderness of Administrative Laze, 70 CoLuM. I. Rev. 612 (1970) ; Rogers \& Hellegers, Book Review, 119 U. PA. L. Rev. 1080 (1971). The Second Circuit has rejected Sive's proposal for expanding the standard of review. Scenic Hudson Preservation Conference v. FPC, 453 F.2d 463 (2d Cir. 1971).

$1484 \mathrm{~K}$. Davrs, supra note $23, \S 30.08$, at 233 . In recent cases involving the FCC, the D.C. Circuit has been less than reticent in stating its reasons for differing. See, e.g., Business Executives' Move for Vietnam Peace v. FCC, 450 F.2d 642 (D.C. Cir. 1971), cert. granted, 405 U.S. 953 (1972) (No. 71-864); Office of Communication of the United Church of Christ v. FCC, 425 F.2d 543 (D.C. Cir. 1969).

149 The frequency of reversal of FCC decisions recently by the D.C. Circuit suggests something less than complete faith in the Commission's policies and fairness. Cf., e.g., notes 408-11 infra \& accompanying text.

150 See FCC v. RCA Communications, Inc., 346 U.S. 86, 91 (1953): "Since the Commission professed to dispose of the case merely upon its view of a principle which it derived from the [organic] statute and did not base its conclusion on matters within its own special competence, it is for to to determine what the governing principle is."

151 See 4 K. DAvis, supra note 23, \$30.08 (1958 \& Supp. 1970).

152 Perhaps the closest a court has come to taking a case away from an agency in the cases considered in this Comment was the D.C. Circuit's disposition of the second United Church of Christ appeal. Office of Communication of the United Church of Christ v. FCC, 425 F.2d 543 (D.C. Cir. 1969); see notes 426-36 infra \& accompanying text. See also Business Executives' Move for Vietnam Peace v. FCC, 450 F.2d 642 (D.C. Cir. 1971), cert. granted, 405 U.S. 953 (1972) (No. 71-864).

153 Thus, Judge Kaufman, writing of the Scenic Hudson case, notes 768-84 infro \& accompanying text, speaks of "[p]ulling out many of the weapons in the arsenal of judicial review that permit a court to skirt the question whether the Federal Power Commission was right or wrong." Kaufman, supra note 16, at 92.

154 The Second Circuit in the second appeal of Scenic Hudson summarized the copious record compiled from the hearing on remand and the concessions made to the environmentalists, recited the customary language dealing with review of questions of fact, and upheld the FPC's decision. The concessions did substantially reduce 
vertently or deliberately ignored information relevant to its decision and that enforcing a procedural requirement--such as the impact statement prescribed by the NEPA ${ }^{155}$ or a public interest group's intervention in a proceeding -is the only viable means of informing the agency. Finally, a court may wish to widen the scope of public participation in order to force the agency to articulate the logic of its value choices in the record in response to arguments and data introduced by the public participant. The record, thus augmented, would facilitate judicial review of agency policymaking.

\section{Public Interest Groups}

If Congress and the courts have little present inclination to impose new values, or priorities among values already held, upon agency decisionmakers, members of the general public seem to have little power to do so. One of the most often repeated criticisms of agencies is that there is little citizen involvement in decisionmaking. ${ }^{156}$ In terms of the due-process-equilibrium model, the criticism is that a proper equilibrium has not been established because certain interests affected by the decisions are not represented before the decisionmaker, who, whether or not his values would permit a sympathetic consideration of those interests if they were represented, gives them little or no consideration in fact. In theory, an office within the agency, such as the Atomic Safety and Licensing Board of the $\mathrm{AEC}^{157}$ or the office of complaint counsel in the FTC ${ }^{158}$ is usually supposed to represent the broader, more general interests of the public not represented by the regulated interests. Often these offices must compromise competing policy positions according to articulated or unarticulated agency priorities, with the result that no one position is argued to the fullest. Full exploration of the information that might be adduced to support each competing policy position, or, indeed, the very knowledge that some problems and policy positions exist at all, is often limited by lack of investigatory resources. ${ }^{159}$ Consideration of some policy positions might be foreclosed altogether by an agency's priorities or its conception of its jurisdiction. ${ }^{160}$ Some policy positions favorable to certain parties, then, are likely to be ignored unless articulated by independent spokesmen skilled in the legal argumentation and factual presentation that are at the heart of administrative decisionmaking.

the visual impact of the project on the landscape. See Scenic Hudson Preservation Conference v. FPC, 453 F.2d 463 (2d Cir. 1971); notes 777, 806.08 infra \& accompanying text.

155 See note 136 supra.

156 See note 18 supra.

157 See notes 825-42 infra \& accompanying text.

158 See notes $656-57,685-86$ infra \& accompanying text.

159 See note 24 supra \& accompanying text.

100 See, e.g., notes 893-900 infra \& accompanying text. 
Public interest groups, so termed largely as a matter of convenience, attempt to serve as such spokesmen. They serve the function of what may be called "public interest representation" before agencies, that is, representation of an otherwise inadequately represented policy position (which may or may not be factually supported or easily susceptible of factual support) formulated to promote an interest which will be affected by the decision to be made. By that representation, they enable the agency to make a more informed, fuller consideration of the problem before it, which is, in terms of the due-process-equilibrium model, ${ }^{161}$ more in the public interest. Two qualifications should be noted. First, the function of public interest representation may be served by others than those usually identified as "public interest groups." An individual might attempt to serve such a function; for example, a recent law school graduate has made several attempts to initiate or intervene in FCC proceedings. ${ }^{162}$ The function might be served by a labor union, ${ }^{163}$ a trade association, ${ }^{164}$ or a competitor. ${ }^{165}$ Second, the concept of an "interest" is as broad or narrow as agencies, courts, and Congress choose to make it in any given case. Individuals and groups may be said to possess numerous narrowly defined interests, many of them competing or conflicting: everyone, for example, presumably has an interest, in the broad sense, in avoiding food poisoning, but a hypochondriac might go to great lengths to maintain a "proper" diet whereas a welfare recipient might get only what food stamps could provide. This Comment speaks of interests in the broader, more abstract sense-for example, the interest of the public in general in clean air-and seeks to distinguish such abstract interests as much as possible from policy positions calculated to advance these interests in a specific factual context. Thus, the interests in clean air might be advanced by a number of alternative policy positions presented by a number of different spokesmen in a given agency context. ${ }^{166}$

Under the above definition, a public interest group need not have an interest that would confer standing to obtain judicial review. ${ }^{167}$ It need only effectively represent a policy position calculated to advance such an interest. Under this theory, intervention, at least in a nontechnical sense of being allowed to present information and policy arguments, should be granted any group which offered expert representation of a relevant policy position not otherwise represented. ${ }^{168}$

161 See notes 129-33 supra \& accompanying text.

162 See notes 389-400 infra \& accompanying text.

163 See notes $516,682-90,845$ infra \& accompanying text.

104 See notes $650,662-63$ infra \& accompanying text.

165 See notes 351-54, 750-51 infra \& accompanying text. But see notes 396-98 infra \& accompanying text.

$166 C f$. text preceding note 681 infra.

167 See notes 49-84 supra \& accompanying text.

168 The intervention granted state and local governments and other government agencies is justified by this rationale, although political accommodation may also play a part. Intervention by competitors or industry advisory committees is sometimes 
What accounts for the relatively recent emergence of groups to present interests which were previously inadequately represented, and what interests are these groups likely to represent? The very existence of such groups is difficult to explain under orthodox theories of such special interest groups as labor unions, trade or industrial associations, and professional associations. ${ }^{169}$ Mancur Olson has argued that the latter resort to collective action-lobbying, contributions to political campaigns, litigation, advertising, and so forth-only where the individual benefit accruing to each member of the group outweighs the individual cost of supporting the collective action, and then, except in the case of very small groups where social disapprobation effectively prevents failure to contribute one's share of the cost, only where there is some additional incentive or coercion, quite apart from the achievement or failure to achieve the collective goal. ${ }^{170}$ The first requisite of collective action-that the benefit to the individual outweigh or at least equal the cost-would seem to be lacking for most public interest groups. They often assert interests, such as control of radioactive waste, ${ }^{171}$ conservation, ${ }^{172}$ preservation of historic landmarks or scenic areas, ${ }^{173}$ prevention of deceptive or misleading advertising, ${ }^{174}$ fair representation of controversial subjects in the broadcast media, ${ }^{175}$ and protection from harmful effects of DDT, ${ }^{176}$ that are shared by persons outside the group, often by every member of a large class or geographic area affected by the agency decision. The benefit their members would derive if their objectives were achieved would not, in monetary terms, repay the requisite expenditure of time, effort, and funds. There is perhaps a satisfaction derived by the members that would make up the deficit in the cost-benefit equation: the personal satisfaction or sense of morality that is derived from participation in what the individual feels is a just cause. That very questionable assumption-that an enhanced sense of moral rectitude can sufficiently compensate for the

granted without regard to the interest represented, on the ground that the competitor or committee possesses special expertise or access to data useful to the agency in making a full consideration of the issues. See, e.g., notes 750-53 infra \& accompanying text.

169 See generally H. Eckstein, Pressure Group Politics (1960); S. Finer, Anonymous Empire: A Study of the Lobby IN Great Britain (1966).

170 In large groups, the additional coercion or incentive is required by the tendency of individuals to accept the benefit without paying their share of the cost: the pressure labor unions are allowed to exert on employees to maintain the integrity of bargaining units is a good example. See M. Olson, JR., The Logic of Collective Action: Public Goods and the Theory of Groups (1965).

171 See Crowther v. Seaborg, 312 F. Supp. 1205 (D. Colo. 1970). 1965).

172 See Scenic Hudson Preservation Conference v. FPC, 354 F.2d 608 (2d Cir.

173 See id.

174 See Campbell Soup Co., [1967-1970 Transfer Binder] Trade Reg. Rep. II 19,261 (FTC 1970), appeal filed sub nom. SOUP, Inc. v. FTC, No. 24,476, D.C. Cir., July 24, 1970; see notes 598-608 infra \& accompanying text.

${ }_{175}$ See Office of Communication of the United Church of Christ v. FCC, 359 F.2d 994 (D.C. Cir. 1966).

176 See Environmental Defense Fund v. HEW, 428 F.2d 1083 (D.C. Cir. 1970). 
insufficiency in monetary terms of a benefit derived through collective actions-is perhaps more easily made in light of the fact that some public interest groups do not bear the financial cost of their activities themselves. ${ }^{177}$

This circumstance, viewed in one light, tends to help balance the cost-benefit equation; viewed in another, it raises serious questions of the reliability of the representation of the group's interest. For example, the work of a major public interest law firm, the Center for Law and Social Policy in Washington, D.C., has been subsidized by major foundations. ${ }^{178}$ Many of the groups represented by the Center could not independently provide themselves with the sort of expert representation required in agency proceedings. To some extent, then, the Center not only represents these groups, but in doing so tends to define their goals and, perhaps, their structure and internal organization as well, if only in the discretion it exercises in choosing the types of cases it will take, what strategies will be used, what remedies sought, what compromises accepted. ${ }^{179}$ The Center and other institutions like it decide, in effect, what interests it is most in the public interest to represent. Critics have suggested that some of these decisions reflect a bias against problems of the poor and in favor of interests, such as those of the consumer and the environmentalist, whose problems are arguably more susceptible to solution through the political process. ${ }^{180}$

There is, at the very least, a danger that a public interest law firm's concept of its client group's interest will not accurately reflect that interest, to the extent that the client group is not well organized in its own right, does not have well-established policies, does not have a working knowledge of the administrative process, is not able to draw upon its own internal information and expertise to support its case, or, if unsatisfied with the firm's presentation of its interest, is unable to afford other representation. One measure of the integrity and legitimacy of a group, and hence its ability to curb misrepresentation of its interest, is its ability to engage in significant collective action (short of presenting its own case before an agency) to promote its interest unassisted. Those groups which do not engage in such action are less able to prevent misrepresentation than those, like the Sierra Club, ${ }^{181}$ Consumers Union, ${ }^{182}$ and Common

177 For example, in Scenic Hudson Preservation Conference v. FPC, 354 F.2d 608 (2d Cir. 1965), the conservation group was "heavily financed by a public spirited citizen." Jaffe, The Citizen as Litigant in Pablic Actions: The Non-Hohfeldian or Ideological Plaintiff, 116 U. PA. L. REv. 1033, 1044 (1968).

178 See Halpern \& Cunningham, supra note 13, at 1104. For other general accounts of the practice of public interest law, see Berlin, Roisman \& Kessler, supra note 13; Cahn \& Cahn, supra note 13; Comment, supra note 13.

179 See Halpern \& Cunningham, siepra note 13, at 1107-10; cf. NAACP v. Button, 371 U.S. 415, 462-63 (1963) (Harlan, J., dissenting).

180 Halpern \& Cunningham, supra note 13, at 1107.

181 See note 788 infra.

182 See note 678 infra. 
Cause, ${ }^{183}$ which do.

The problem of misrepresentation of the interest asserted is not limited to those groups which do not engage in other significant collective action unassisted. It is present when a group represents two or more potentially competing interests. Such groups are not ordinarily thought of as public interest groups, although they are allowed access to administrative proceedings to present information not otherwise easily available to an agency, and in that sense further the public interest. Examples include large trade or professional organizations, ${ }^{184} \mathrm{com}$ petitors allowed to intervene in a role analogous to that of the "private attorneys general," 185 and large labor unions that may claim to represent their members' interest as consumers or environmentalists. ${ }^{186}$ Similarly, it is perhaps too easily assumed that municipalities or other governmental units, which are often allowed to intervene in certain proceedings as of right, ${ }^{187}$ will accurately reflect the balance of the competing interests within their jurisdictions. ${ }^{188}$ Finally, the problem of misrepresentation of the asserted interest induced by competing interests may be present in groups like that in Palisades Citizens Association v. $C A B,^{189}$ whose members' interest in environmental effects of an agency decision may be difficult to distinguish from their individual interests as property owners.

183 But cf. Schrag, Common Cause: New Paths for WASP Elites, 2 Sociaz Policy, Nov.-Dec. 1971, at 29, 31 :

Common Cause was to be a membership organization relying not on a few large donors but on the fifteen-dollar annual fee that each of a hundred thousand concerned citizens would contribute. . . . Common Cause suggested that the thing called the Public Interest is distinguishable (to certain people) from particular interests; the Public Interest, moreover, was more noble than particular interests and, almost by definition, could be articulated only by those who have no overriding special interests to defend ...., who were already sufficiently secure or established (or saintly?) to be incorruptible and selfless. Such people must necessarily be individuals who place themselves into an "American" tradition that is beyond class or race or time, beyond even the memory of having made it. It is only the Establishment which can deny the possibility that the Public Interest is simply an arrogant misunderstanding of its private concerns, however selfless it may regard them. It is only the Establishment which can toss out the word "we" as if it meant everybody, as if there were no "us" and "them." The crisis (real or, again, imagined) which gave impetus to Common Cause is the breakdown of that "we"; it is the dawning realization that when someone says "we" as if it did mean everybody there is a cacophony of count-me-outs.

184 See notes 650, 662-63 infra \& accompanying text.

185 See, e.g., notes 351-54 infra \& accompanying text.

186 See notes 516, 682-90, 845 infra \& accompanying text.

187 See note 734 infra \& accompanying text.

188 In Citizens for Allegan County, Inc. v. FPC, 414 F.2d 1125 (D.C. Cir. 1969), a citizens group intervened but was unable to present its case against the sale of power facilities to a private utility which had been approved by referendum. The case presents a striking example of dissent from the prevailing consensus of the community, which might have altered the Commission's view of the equities if a hearing had been allowed.

189420 F.2d 188 (D.C. Cir. 1969). See notes 533-47 infra \& accompanying text. 


\section{Considerations Influencing the Form of Participation}

What considerations, then, beyond those outlined by Shapiro for permissive intervention before courts should govern agency discretion in formulating its intervention policy? That there are many types of administrative proceedings and that within each type the effect of a decision may be limited strictly to a single party or may extend to an entire segment of the national economy suggest a similar variety in forms intervention might take, depending upon the type of proceeding, the intervenor's interest, and his potential contribution.

Three broad types of administrative proceedings are exemplified in the analyses below of the individual agencies: proceedings which formulate rules of general applicability; proceedings which allocate resources or privileges; and proceedings which enforce prohibitions created by statute. Of course, these areas often overlap. An FCC license renewal hearing, for example, may combine all three types. Before a broadcast license may be reallocated, there may be charges of past violations of the fairness doctrine which would raise the possibility of enforcing sanctions, or there may be complaints relating to the quality of programming or objections to the frequency or fairness of advertising which might raise novel policy questions more commonly considered in the rulemaking context. Enforcement proceedings in the FTC are sometimes used by the agency to establish new rules applicable throughout an industry. ${ }^{190}$ Although these examples point out the danger in analyzing proceedings according to their form rather than the issues they consider, ${ }^{191}$ some general observations may be made of each of the types of proceedings mentioned above.

The need for broad public participation, including participation by public interest groups, is most obvious in agency rulemaking. ${ }^{192}$ Rulemaking proceedings setting future standards or policies are "legislative" in the sense that many interests are potentially affected, many interrelated issues involved, and a variety of solutions possible. Rulemaking should be modeled on the political process to the fullest extent practicable. In areas where rulemaking is currently employed, the interests of large segments of the public, and particularly the poor, are said to be inadequately represented: there is not enough investigation of the effects of contemplated rules on these interests initiated by the agencies themselves, there is little coordination of the efforts of the unrepresented groups to participate, and notice of contemplated rulemaking is inadequate. Indeed, matters relating to "public property, loans, grants, bene-

190 Problems unique to enforcement proceedings are treated below in the context of the FTC.

191 See Robinson, The Making of Administrative Policy: Another Look at Rulemaking and Adjudication and Adninistrative Procedure Reform, 118 U. PA. L. REv. 485 (1970).

192 Formal rulemaking is governed by the Administrative Procedure Act $\$ 4$, 5 U.S.C. $\$ 553(1970)$. 
fits or contracts" ${ }^{193}$ _matters most likely to affect the poor-are specifically excepted from the requirements of the APA for notice and participation "through the submission of written data, views, or arguments with or without opportunity for oral presentation" ${ }^{194}$ or through "the right to petition for the issuance, amendment, or repeal of a rule." ${ }^{195}$ It has been suggested that these exceptions, and those for "interpretative rules, general statements of policy, or rules of agency organization, procedure or practice" 196 be eliminated or modified..$^{197}$ Several commentators have suggested that agencies employ their rulemaking authority much more broadly than they now do, ${ }^{198}$ and several public interest groups have attempted to initiate such rulemaking with varying degrees of success. ${ }^{199}$ Moss v. $C A B,{ }^{200}$ despite the narrowness

$193 \mathrm{Id}$.

$194 I d . \S 553(\mathrm{c})$.

$195 \mathrm{Id} . \$ 553(\mathrm{e})$. For analysis and criticism of these exceptions, see Bonfield, Public Participation in Federal Rulemaking Relating to Public Property, Loans, Grants, Benefits, or Contracts, 118 U. PA. L. REv. 540 (1970).

1965 U.S.C. $\$ 553$ (b) (A) (1970).

197 See, e.g., Bonfield, Some Tentative Thoughts on Public Participation in the Making of Interpretative Rules and General Statements of Policy Under the A.P.A., 23 AD. L. REv. 101 (1971) ; Bonfield, supra note 18.

198 See, e.g., Clagett, Informal Action-Adjudication-Rulemaking: Some Recent Developments in Federal Administrative Law, 1971 Duke L.J. 51 ; Robinson, supra note 191 ; Shapiro, The Choice of Rulemaking or Adjudication in the Development of Agency Policy, 78 Harv. I. Rev. 921 (1965). For an example of the use of rulemaking to expedite the hearing process, see note 917 infra \& accompanying text.

199 On June 8, 1971, the Project for Corporate Responsibility and the Natural Resources Defense Council filed a petition before the Securities and Exchange Commission for rulemaking proceedings "in order to require more adequate disclosures of present and potential environmental effects of registrants' activities" in keeping with the mandate of the NEPA, and to "modify its forms for registration of securities under the Securities Act of 1933 and its current and periodic report forms to require more adequate disclosures by registrants with respect to their compliance with the requirements and policies of the federal Equal Employment Opportunity Act and Executive Order 11246 relating to discriminatory hiring practices on the part of federal contractors." Petition of Project for Corporate Responsibility and Natural Resources Defense Council 1, June 7, 1971, copy on file in Biddle Law Library, Univ. of Pa. Law School. Concerning the environmental issue, Chairman Casey of the SEC subsequently responded:

To go further to the extent suggested in the petition . . . raises difficult questions concerning the purpose and function of the Securities and Exchange Commission. Traditionally, we have viewed our function in the disclosure area ... to be that of requiring inclusion of information which will enable a prudent investor to make an intelligent judgment as to the merits of a security considered in economic terms. ...

. . .

We recognize that Section 102 of the [NEPA] may well have broadened our disclosure obligations but we are still seeking to determine the extent to which this section calls for a major reorientation of the mandate given us by Congress in 1933 and 1934.

Letter from Chairman Casey to Representative John Dingell, Aug. 6, 1971, copy on file in Biddle Law Library, Univ. of Pa. Law School. As of Sept. 27, 1971, the Commission had made no official reply to petitioners. Interview with Roger S. Foster of the Center for Law and Social Policy, in Washington, D.C., Sept. 27, 1971. See Schwartz, The Public Interest Proxy Contest: Reflections on Campaign GM, 69 MICH. L. Rev, 419 (1971). Another attempt-before the FCC-to initiate rulemaking met with more success. See note 338 infra. 200430 F.2d 891 (D.C. Cir. 1970). See notes 495-509 infra \& accompanying text. 
of its technical holding, indicates a growing apprehensiveness on the part of courts that the intricacies of summary rulemaking procedures may be used to foreclose comment or protest by members of the public. Calvert Cliff' Coordinating Committee v. AEC ${ }^{201}$ reveals a kindred willingness to scrutinize rules intended to implement national policy as articulated by the NEPA. In general, however, agency utilization of and public participation in, rulemaking have been limited. ${ }^{202}$ The scope of participation is narrower than in adjudicative proceedings, particularly where notice and a hearing are not mandatory, and the standard of judicial review of rulemaking under section 4 of the APA appears even less probing than that of review of adjudicative proceedings. ${ }^{203}$

While, under the APA, any person may "petition for the issuance, amendment, or repeal of a rule," ${ }^{204}$ the choice between rulemaking and adjudication is, of course, for the agency, and not those affected by the decisions, to make. ${ }^{205}$ In some instances, however, a hearing is required where initiated by a complaining party, and this normally affects the complainant's intervention rights. ${ }^{206}$ Greater use of rulemaking by agencies might diminish the procedural rights and scope of judicial review now available to public interest groups in the adjudicative context. On the other hand, public interest groups are usually better prepared to address the broad questions of policy upon which rulemaking proceedings often focus than to marshal the expertise and factual data upon which adjudicative proceedings tend to focus. ${ }^{207}$ Statements of opinion by public interest groups, even if unsupported by expert testimony and factual data, are more appropriate to rulemaking because of its more "legislative" format. "The failure of many agencies to rely upon informal rulemaking proceedings rather than trial-type hearings to decide general policies is itself a significant cause for public intervention in trial-type proceedings." 208 The danger that regulated interests will overwhelm both the agency and public participants with finely focused expertise that is both difficult to counter and obscurative of broader policy considerations, is perhaps diminished when decisions involving broader questions of policy are made in the rulemaking context. ${ }^{209}$ The

201449 F.2d 1109 (D.C. Cir. 1971).

$202 C f$. note 18 supra \& accompanying text.

203 See Robinson, supra note 191, at 488 n.15.

$20 \pm 5$ U.S.C. $\$ 553(\mathrm{e})(1970)$.

205 See NLRB v. Wyman-Gordon Co., 394 U.S. 759 (1969); SEC v. Chenery Corp., 332 U.S. 194 (1947); Bernstein, The NLRB's Adjudication-Rulemaking Dilemma Under the Administrative Procedure Act, 79 YALE L.J. 571 (1970).

206 See Shapiro, supra note 37, at 726-29.

207 SOUP's lack of success in the Firestone case may be an example. See notes 658-81 infra \& accompanying text.

208 Gellhorn, supra note 18 , at 378.

209 In Udall v. FPC, 387 U.S. 428, 436 (1967), for example, the decision below, which focused on whether the purposes of a proposed hydroelectric power project would be better served by private or federal development, was reversed for failure to consider the threshold question whether any project should be constructed. 
regulated industries, furthermore, have the resources to endure an extended adjudicative proceeding.

Beyond these areas of agency jurisdiction subject to the notice and public participation provisions of either rulemaking or formal adjudication, lies the vast realm of informal agency action which has long been a sacred preserve virtually unviolated by public scrutiny or judicial intervention. ${ }^{210}$ The reluctance of courts to entertain appeals from agency actions for which there is no hearing record or other articulation of policy may in many instances indicate a sound deference to the agency's control over its own resources and priorities, but it has become strikingly clear that greater disclosure of and public participation in informal agency decisionmaking is necessary to secure confidence in the administrative process. ${ }^{211}$ While the need for informal adjudication and policymaking is uncontested, openness and the structuring of discretion can operate to minimize the dangers of covert arbitrariness, bias, and inconsistency. ${ }^{212}$ The due process clause of the Constitution demands some minima of procedure and articulated standards of decision to ensure fairness in informal adjudications. ${ }^{213}$ Beyond this "ultimate source" of power to compel formalization of procedure and greater articulation of policy, the governing statutes often can be read to allow review of informal agency action and to compel the institution of more formal proceedings. ${ }^{24}$ Aided by the presumption of reviewability, ${ }^{215}$ courts have expanded the outer periphery of effective judicial review by closely examining administrative inaction or delay ${ }^{216}$ and by assuming a pragmatic approach to the major exception to reviewability, the committed-to-agency-discretion doctrine. ${ }^{217}$

210 See Clagett, supra note 198, at 55.

211 See Gardner, The Procedures By Which Informal Action Is Taken, reprinted in Hearings on S. 1177 \& H.R. 10835 Before the Subcomm. on Executive Reorganization \& Government Research of the Senate Comm. on Government Operations, 92d Cong., 1st Sess. 233 (1971).

212 See K. Davis, Discretronary Justice 97-120 (1969).

213 See Goldberg v. Kelly, 397 U.S. 254 (1970); Holmes v. New York City Housing Authority, 398 F.2d 262 (2d Cir. 1968); Hornsby v. Allen, 326 F.2d 605. (5th Cir. 1964).

214 See Clagett, supra note 198, at 66; Environmental Defense Fund, Inc. v. Ruckelshaus, 439 F.2d 584 (D.C. Cir. 1971). Butt cf. Nor-Am Agricultural Products, Inc. v. Hardin, 435 F.2d 1151 (7th Cir. 1970).

215 See Abbott Laboratories v. Gardner, 387 U.S. 136, 139-41 (1967).

216 See Environmental Defense Fund, Inc. v. Hardin, 428 F.2d 1093 (D.C. Cir. 1970) ; Goldman, Administrative Delay and Judicial Relief, 66 MrcH. L. REv. 1423 (1968).

217 See 5 U.S.C. $\$ 701$ (a) (1970). One influential article has suggested that reviewability of discretionary agency action be determined by analyzing in each case the interest of the agency in informal proceedings, the burden on the courts of increased review, and the interests of the affected individuals. Saferstein, supra note 33, at 371. See Hahn v. Gottlieb, 430 F.2d 1243 (1st Cir. 1970); Medical Comm. for Human Rights v. SEC, 432 F.2d 659, 666-67 (D.C. Cir. 1970). By examining the scope of an agency's authority and the congressional scheme, reviewing courts may determine the extent of agency discretion, the expertise necessary to decision, the managerial nature of the agency, the usefulness of informal proceedings, the effectiveness of review, and the desirability of expeditious operation of the agency. 
In Citizens to Preserve Overton Park, Inc. v. Volpe, ${ }^{218}$ the Supreme Court has recently attempted to define the scope of review of informal agency actions. The Court found that section $10(\mathrm{e})$ of the $\mathrm{APA}^{219}$ demands thorough, searching review to determine whether an agency has exceeded the scope of its authority, whether there has been an abuse of discretion, and whether procedural requirements have been observed by the agency. ${ }^{220}$ Though the Court refused to impose a requirement that formal findings and statements of reasons accompany informal decisions, ${ }^{221}$ reviewing courts were instructed to examine critically "the full administrative record," treating restrospective findings with caution, and were authorized, where there are no formal findings and where additional explanation is necessary to make judicial review effective, to "require the administrative officials who participated in the decision to give testimony explaining their action." ${ }^{222}$ While the Court refused to require contemporaneous findings for informal agency decisions, Overton Park would nevertheless appear to lend impetus to increased formalization of informal processes. ${ }^{223}$

Adjudicative allocation proceedings figure prominently in the developments within the agencies considered below. In general, they involve the grant of some privilege-a license to broadcast, to build a hydroelectric project, a pipeline, or nuclear power plant, or to provide air transportation for a given locality - that may be enormously profitable to the recipient but potentially harmful not only to his competitors but also to members of the public residing in the area affected by the license. Just as rulemaking sets standards or policies for the future, many of these allocation proceedings will affect a multitude of interests for an extended period of time. The immediate impact of the allocation of the resource or privilege heightens the desire of affected interests to participate. On the other hand, intervenors may have less of a role to fulfill in trial-type proceedings with an "individualized impact" on the regulated interest. ${ }^{224}$

See Saferstein, supra note 33, at 377-95. After considering these factors, courts should also inquire into the possibilities of limited review of separable issues. $S e e$ id. 395-96. See also Berger, Administrative Arbitrariness: A Synthesis, 78 Yale L.J. 965 (1969) ; Davis, Adninistrative Arbitrariness is Not Always Reviezvable, 51 MiNN. L. REV. 643 (1967).

218401 U.S. 402 (1971). See The Supreme Court, 1970 Term, 85 Hanv. L. REv. $38,315-25$ (1971).

2195 U.S.C. $\$ 706(1970)$.

220401 U.S. at 415-17. To find an abuse of discretion, reviewing courts "must consider whether the decision was based on a consideration of the relevant factors and whether there has been a clear error of judgment." Id. at 416.

221 Id. at 417.

$222 I d$. at 420 . The holding was thus an explicit limitation on United States v. Morgan, 313 U.S. 409 (1941), which prohibited courts from inquiring into the mental processes of administrative decisionmakers. Id.

223 See Clagett, supra note 198, at 62-63; The Supreme Court, 1970 Term, supra note 218 , at $321-22$.

224 Cf. Gellhorn, supra note 18, at 379-80. 
Such proceedings already attract a number of parties, and hence procedures have been developed which attempt to accommodate them. The $\mathrm{CAB}$ in particular has developed relatively refined rules regarding intervention which attempt to adjust the degree of permitted participation to the intensity of the applicant's interest and the applicant's ability to contribute information relevant to specific issues ${ }^{225}$ or the overall decision to be made. These rules are analyzed extensively below, and an attempt is made to establish more precisely standards that should guide the Board's discretion in granting procedural privileges to those whose interest does not seem sufficient to entitle them to intervention with all the rights of original parties. ${ }^{226}$ This flexible accommodation is desirable, especially since party status is not normally necessary to the right to appeal an adverse decision. ${ }^{227}$ The proposed addition to the CAB's rule on limited intervention is not aimed at limiting the Board's discretion, but rather at encouraging the Board to articulate its reasoning in particular cases more fully. Shapiro's proposed changes to rule 24 of the Federal Rules of Civil Procedure, in contrast, are aimed at broadening a court's authority to grant permissive intervention. Though most agencies already have such authority, they have not articulated standards as precise as those suggested by Shapiro and those adopted by the CAB.

If an applicant for intervention possesses special expertise or information, including opinion and general legal theories, not otherwise available to the decisionmaker, he should be allowed whatever procedural privileges he needs, to present that information effectively. The possible range of privileges includes the submission of written statements and factual exhibits, ${ }^{228}$ oral presentations before the hearing examiner or the full commission, ${ }^{229}$ submission of briefs, ${ }^{230}$ the privilege to comment on the record and the hearing examiner's findings, ${ }^{231}$ the privilege to present witnesses and to cross-examine, ${ }^{232}$ and the use of subpoena and discovery powers. ${ }^{233}$ Often, the grant of privileges much less extensive than those granted full parties would be sufficient to allow an applicant to present its information effectively. Rules which limit certain privileges to full parties seem undesirable, to the extent that the privilege in question might serve the purposes of limited intervention and to the extent it might induce applicants to insist on full party status.

225 See notes 658-63 infra \& accompanying text.

226 See notes 510-32, 567-80 infra \& accompanying text.

227 Cf. Shapiro, supra note 37, at 767. But of. notes 682-707, 746-55 infra \& accompanying text.

228 See note 530 infra \& accompanying text.

229 See note 527 infra \& accompanying text.

230 See note 530 infra \& accompanying text.

231 See note 529 infra \& accompanying text.

232 See note 662 infra \& accompanying text.

233 See notes 616-22, 661 infra \& accompanying text. 
A case like Palisades Citizens Association v. $C A B^{234}$ demonstrates the wise use of agency discretion in granting privileges sufficient to convey the proffered information.

Quite apart from a petitioning intervenor's ability to present information, another general consideration is the effect a decision may have on his interest. This consideration may be more binding on courts than agencies, ${ }^{235}$ but Welfare Rights seemed to base the fundamental right to participate, for purposes of making effective the right of review, on the fact that the welfare recipients' interest fell within Data Processing's "zone of interests." Given the potential expansiveness of that zone, some agencies may well be forced to allow intervention where previously they had denied it on the ground that the interest asserted was too remote. ${ }^{236}$

Must any applicant who alleges an interest within that zone be allowed to participate, even if it appears that he could adduce no information relevant to the inquiry and that there may be more suitable representatives of the applicant's interest? ${ }^{237}$ The question is far from academic: in the highly technical context of AEC proceedings, for example, it has been advocated that intervenors adopt tactics of delay and outright confrontation rather than undertake the costly burden of rebutting the evidence introduced in support of license applications. ${ }^{238}$ If one subscribes to the most pessimistic view of the current state of affairs within the agencies generally, ${ }^{239}$ perhaps this latter sort of participation-highly political and often disruptive-serves the arguably valid function of dramatizing administrative failings in order to initiate changes in agency policy, staff, and attitude. ${ }^{240}$ There is the possibility, however, that intervention by a citizens' group might be abused. A conspiracy by members of a regulated industry to employ the privilege of intervention as part of a scheme to drive a competitor out of business

234420 F.2d 188 (D.C. Cir. 1969). See notes 533-66 infra \& accompanying text. 235 See note 114 supra.

236 Reasonable geographic proximity, for example, remains a general requirement in certain proceedings before the $A E C, C A B$, and FCC. The fact that petitioner resided outside the area arguably affected by a proposed site has been a ground articulated by the AEC in denying a petition to intervene. See notes 869-71 infra \& accompanying text. Similarly, "off-line" cities or cities alleging non-economic interests do not have a clear right to intervene under present $\mathrm{CAB}$ policy, see notes 520-23 infra \& accompanying text, and petitioners challenging broadcast license renewals must reside within the service area. See notes 389-95 infra \& accompanying text.

237 The FCC's treatment of attempts to intervene by an individual, Anthony Martin-Trigona, illustrates the problems that might confront an individual or a little-known, poorly-financed group. See notes 389-400 infra \& accompanying text. 238 See note 877 infra \& accompanying text. Gellhorn, supra note 18 , at $28-29$, minimizes the significance of this point.

239 See notes 17-31 supra \& accompanying text.

240 The agency itself might encourage such participation in certain instances where it would prefer not to advocate a new policy position for fear of more active initial industry opposition. "Affirmative disclosure," originally proposed by an intervenor, is now proposed as a remedy by the FTC itself. See note 669 infra \& accompanying text. 
may violate the antitrust laws. ${ }^{241}$ In the recent case of California Motor Transport Co. v. Trucking Unlimited ${ }^{242}$ the Supreme Court found that, while "it would be destructive of rights of association and of petition to hold that groups with common interests may not, without violating the antitrust laws, use the channels and procedures of . . . federal agencies and courts to advocate their causes and points of view," 243 "[a] combination of entrepreneurs to harass and deter their competitors from having 'free and unlimited access' to the agencies and courts [and] to defeat that right by massive, concerted, and purposeful activities of the group" 244 violates the Sherman Act. Concerted efforts to influence legislation and law enforcement ${ }^{245}$ or perhaps "agency action on broad policy issues of a quasi-political nature" ${ }^{446}$ may be given wide latitude as protected political expression, but in an adjudicatory forum "a pattern of baseless, repetitive claims may emerge which leads the factfinder to conclude that the administrative and judicial processes have been abused." ${ }^{247}$ NAACP v. Button ${ }^{248}$ would appear to protect the right to advocate vigorously a course of corporate litigation strategy, except where "substantial regulatory interest, in the form of substantive evils flowing from [the cooperative] activities" ${ }^{249}$ can be shown. Any special interest group that systematically engages in a program of opposing a regulated industry by repeatedly and unmeritoriously invoking the legal machinery of the government's adjudicative processes, so as to delay or impede substantially the easy access to those procedures, may be enjoined or perhaps assessed for consequential damage.

The adoption of a dilatory or obstructionist strategy may not be warranted; ${ }^{250}$ the more constructive approach would seem to be to seek greater flexibility in the procedural rules governing intervention and to provide the public interest intervenor with the financial means to make an effective case, rather than simply to announce a presence and to present a general legal argument. ${ }^{251}$ A number of public interest

241 See, e.g., Slick Airways, Inc. v. American Airlines, Inc., 107 F. Supp. 199 (D.N.J.), appeal dismissed sub nom. American Airlines, Inc. v. Forman, 204 F.2d 230 (3d Cir.), cert. denied, 346 U.S. 806 (1953); United States v. Association of Am.

R. Rs., 4 F.R.D. 510 (D. Neb. 1945).

242404 U.S. 508 (1972).

243 Id. at $510-11$.

$244 \mathrm{Id}$. at 515.

245 See UMW v. Pennington, 381 U.S. 657 (1965) ; Eastern R.R. Presidents

Conference v. Noerr Motor Freight, Inc., 365 U.S. 127 (1961).

246 Costilo, Antitrust's Newest Quagmire: The Noerr-Pennington Defense, 66

Mich. L. Rev. 333, 356 (1967).

247404 U.S. at 513. See Note, The Brakes Fail on the Noerr Doctrine, 57

CaltF. L. Rev. 519 (1969).

248371 U.S. 415 (1963).

249 Id. at 444 . Cf. Note, supra note 247 , at 536-39.

250 Courts may be inclined in the future to impose more responsibility on the agencies to explore certain issues. Cf. Scenic Hudson Preservation Conference v. FPC, 354 F.2d 608 (2d Cir. 1965); Committee for Nuclear Responsibility, Inc. v. Seaborg, No. 71-1732 (D.C. Cir. Oct. 5, 1971).

251 See notes 285-316 infra \& accompanying text. 
organizations have sponsored a set of model intervention rules which, although admirable in their emphasis on broader public participation, fail to distinguish various types of agency proceedings and therefore provide a uniform standard for all. ${ }^{252}$

Agencies should, first of all, attempt to improve the mechanisms whereby notice of contemplated agency activity is given to persons potentially affected. ${ }^{253}$ At present, notice is not calculated to reach all affected members of the public, is often couched in general terms which mean little to the inexpert, ${ }^{254}$ and is not given in time to allow outsiders to prepare a well-documented case in opposition to the contemplated action. $^{255}$ A related problem is the timeliness of an application for intervention. In the past, courts have upheld denials of intervention for want of a timely application, in the interest of preventing delay. ${ }^{256}$ The agencies generally have discretion to grant extensions, ${ }^{257}$ which in some instances appears to have been exercised somewhat inconsistently ${ }^{258}$ and in others arbitrarily to deny an otherwise meritorious application. ${ }^{259}$ The frequently inadequate notice and the financial constraints under which public interest intervenors operate should be given much more consideration by agencies and courts in determining what constitutes good cause shown for failure to meet deadlines.

The denial of intervention or of any procedural privilege the intervenor asserts is necessary for a proper presentation of its case should be immediately appealable to an intermediate board of appeal (if the agency has established one ${ }^{260}$ ), to the full commission, and to a court. Stays of proceedings need not be granted in every such appeal. ${ }^{261}$ Denials of intervention potentially affect the reliability of the determination of the issues, ${ }^{262}$ and this consideration should outweigh the concern for preventing delay occasioned by such appeals.

The value of cross-examination has been questioned in some contexts, particularly where the testimony is of a highly technical nature which would seem to lend itself equally well to presentation through

252 See note 18 supra.

253 Gellhorn, supra note 18, at 398-403.

254 See notes $420-21,685$ infra \& accompanying text.

255 Cf. notes 876-92 infra \& accompanying text.

256 See notes 412-16, 864-65 infra \& accompanying text.

257 See, e.g., note 416 infra (FCC); 18 C.F.R. $\$ 1.8$ (d) (1972) (FPC).

258 Compare Transwestern Pipeline Co., 35 F.P.C. 334 (1966) (intervention denied, but applicant Dep't of Health, Education \& Welfare allowed to file brief amicus curiae), with Columbia Gulf Transmission Co., 35 F.P.C. 642 (1966) (applicant HEW allowed intervention in factually indistinguishable case).

259 See note 415 infra \& accompanying text.

260 See generally Gellhorn \& Larsen, Interlocutory Appeal Procedures in Administrative Hearings, 70 MicH. L. REv. 109 (1971).

261 Cf. Shapiro, supra note 37, at 748-51, 762-63.

262 See note 107 supra \& accompanying text. 
written statements and exhibits. ${ }^{263}$ On the other hand, cross-examination may be necessary to prevent broader issues from being obscured by a narrow focus on technical matters, to prevent factual inconsistencies from being buried in the record, and to bring out pro-industry orientation of expert witnesses or staff witnesses. ${ }^{264}$

Discovery of information in the possession of regulated interests or in the possession of the agency itself should be more widely available to the public interest intervenor. Possible prejudice to respondents in enforcement proceedings, protection of confidential information such as trade secrets or financial data not available to the investing public, and the possibility of harassing or unduly burdening the party subject to the order must, of course, be taken into account to limit the scope of discovery or to form protective orders. "Even though a public intervener is frequently allowed to participate because of its particular information or expertise, discovery may be necessary in order for it to protect its position or complete its preparation." ${ }^{265}$ So long as the intervenor has raised and carefully framed issues relevant to the proceedings, liberal discovery privileges would facilitate the effective factual presentation that has too often been lacking in intervenors' appearances before agencies. ${ }^{206}$

The agency must, of course, have discretion to limit the issues considered in any given proceeding. Certain issues may properly be foreclosed as being outside the agency's jurisdiction, but there is a tendency on the part of Congress and the courts to widen agency jurisdiction. ${ }^{267}$ In areas within an agency's jurisdiction, the grant of intervention to address certain issues but not other closely related issues might be difficult to justify. ${ }^{268}$ Most of the cases, however, center either upon whether the issue sought to be raised falls within the agency's jurisdiction or upon whether an issue clearly relevant to the proceeding was explored fully enough. The degree of discretion an agency has to limit intervention to raise issues within its jurisdiction and arguably relevant to the proceeding awaits judicial clarification. ${ }^{260}$

A further problem which awaits explication is the extent to which an agency may exclude one applicant for intervention in favor of another which is more "representative" or appears better able to present information and expertise. In the Palisades case, ${ }^{270}$ for example, the

263 See text following note 559 infra; Spritzer, Uses of the Snmnnary Power to Suspend Rates: An Examination of Federal Regulatory Agency Practices, 120 U. PA. L. Rev. 39, 95 (1971). See also Prettyman, How to Try a Dispute Under Adjudication by an Adninistrative Agency, 45 VA. L. Rev. 179, 190 (1959).

$264 \mathrm{Cf}$. note 886 infra \& accompanying text.

265 Gellhorn, stipra note 18 , at 385.

266 See notes 616-22 infra \& accompanying text.

267 See notes $135-55$ supra \& accompanying text; cf. note 199 supra.

268 See note 662 infra \& accompanying text.

269 Cf. Comment, supra note 94, at 576-78.

270 See note 234 supra. 
court seems to have assumed that another intervenor, the Department of Transportation, adequately represented the interests of the citizens' group so as to justify the denial of procedural privileges to that group. Would a similar assumption have been justified if a militant black power organization had sought to intervene independent of the National Welfare Rights Organization in Welfare Rights, ${ }^{271}$ or an organization like the $\mathrm{Ku}$ Klux Klan had sought intervention independent of the church and the NAACP in United Church of Christ? ${ }^{272}$ Finally, if agencies like the Consumer Protection Agency ${ }^{273}$ are established, to what extent will their participation preclude participation by public interest organizations?

Professor Ernest Gellhorn, to some extent reflecting Shapiro's suggested approach to permissive intervention in court actions, ${ }^{274}$ has recommended that agencies exercise the power to select the most appropriate intervenor by examining (1) the nature of the contested issues; (2) the intervenor's interest in the outcome; (3) the adequacy of representation of the intervenor's interest by existing parties; (4) the ability of the intervenor to represent its interest vigorously; and (5) the cost and delay occasioned by the intervention. ${ }^{275}$ Such criteria could also be employed to apportion procedural privileges among intervenors. ${ }^{276}$ The criterion requiring some demonstrable interest be advanced "serves to identify not only the contribution which the intervener can make to the administrative hearing, but also the right of those who will be significantly affected by an agency's decision (even though the immediate, direct impact may not be significant or distinct) to be afforded a reasonable opportunity to be heard." 277 This criterion, of course, finds its antecedents in the private-attorney-general concept, which looked to a party's interest as a barometer of the intensity and reliability of the arguments he would forward. ${ }^{278}$ Whether an interest is adequately represented by an agency depends in part upon the nature of the proceeding ${ }^{279}$ and upon the degree to which the agency is thought to be influenced by the regulated industry. ${ }^{280}$ Whether an intervenor is a "responsible and representative [group] eligible to intervene" ${ }^{281}$ may turn on whether it has "by [its] activities and conduct . . . ex$578-80$.

271 See notes $94-113$ supra \& accompanying text; Comment, supra note 94 , at

272 See notes 363-76 infra \& accompanying text.

273 See notes 306-21 infra \& accompanying text.

274 See notes 114-20 supra \& accompanying text.

275 Gellhorn, supra note 18 , at 376-83.

276 Id. 387. Cf. notes 524-32 infra \& accompanying text.

277 Gellhorn, supra note 18 , at 380.

278 See note 53 supra \& accompanying text.

279 Reasons for limiting public participation in adjudicative proceedings are discussed below in the context of the FTC.

280 See note 19 supra \& accompanying text.

281 Office of Communication of the United Church of Christ v. FCC, 359 F.2d 994, 1005 (D.C. Cir. 1966). 
hibited a special interest" ${ }^{282}$ in the contested issues and has the cohesive organization and resources to present its views effectively. If, however, this latter consideration is consistently decisive of the choice of an intervenor, there is the danger that the favored group will establish its hegemony as the spokesman for a point of view. ${ }^{283}$ Professor Gellhorn himself notes that his final criterion, the cost and delay attributable to intervention, "cannot be legitimately charged as a drawback of public interest group participation, [if] a prior judgment has been made that consideration of [the issues raised by an intervenor] is essential to successful performance of the agency's mandate." 284

\section{E. Proposals to Facilitate Public Participation}

If intervention by public interest groups is to mean anything more than announcing a presence, presenting general legal arguments without supporting factual data or expertise, and on occasion dramatizing an agency's inadequate consideration of certain issues, the problem of funding must be surmounted. "Assuring the legal rights of public interest representatives to participate in regulatory proceedings is a vital first step. It is, however, only a first step. Without further affirmative action to assure that public representatives actually appear, the legal right to participate will largely be a symbolic-perhaps merely a cosmetic-advance." 285 The cost of participation-attorneys' fees, fees for expert witnesses, expenses of marshalling and presenting factual data, and transcript costs and similar charges-may effectively inhibit participation by any but the regulated interests. ${ }^{286}$ The present controversy is whether public interest participation should be financed with public funds and, if so, what form such financing should take. Resistance to public financing of such participation is evidenced by the controversy over tax exemptions for public interest law firms ${ }^{287}$ and the opposition of groups such as the United States Chamber of Commerce to the proposed Consumer Protection Agency (CPA). ${ }^{288}$

Public financing of public interest participation might take many forms. It has been suggested that the agencies themselves should bear most of the transcript, multiple copy, and other incidental costs asso-

282 Scenic Hudson Preservation Conference v. FPC, 354 F.2d 608, 616 (2d Cir. 1965), cert. denied, 384 U.S. 941 (1966).

283 At the Administrative Conference hearing on Recommendation 28, see note 18 supra, Malcolm S. Mason noted the danger that intervention might be limited "to a single representative of a particular interest, and thus will appear to give credentials to that group as 'the' representative of . . . [that] citizen interest however characterized."

284 Gellhorn, supra note 18 , at 383.

285 Lazarus \& Onek, supra note 19, at 1096. text.

286 See notes 447-73 (FCC), 708-21 (FTC), 785-91 (FPC) infra \& accompanying

287 See Garrett, Federal Tax Limitations on Political Activities of Public Interest and Edncational Organizations, 59 GEo. L.J. 561 (1971); Halpern \& Cunningham, supra note 13 , at 1109 .

288 See Hearings, supra note 18, at 173. 
ciated with those formal proceedings in which the public may participate ${ }^{289}$ and that "in-house" expertise of federal agencies or neutral experts appointed by the agency deciding the issue should be made available to public participants. ${ }^{290}$ Certainly, the efforts of an active investigative staff could alleviate the burden on, and perhaps the need for, public representatives. ${ }^{201}$

Numerous solutions have been offered to what is perhaps the most perplexing problem-financing attorney and expert witness fees. One approach would create new money-damage remedies, or class actions permitting the consolidation of small claims, to encourage private practitioners to take cases on a contingent fee basis. ${ }^{292}$ Assessing the regulated interests for fee awards or the cost of public representation could also provide an incentive, ${ }^{293}$ but the dangers of imposing new liabilities of indeterminate extent on those interests, the inefficiency of the contingent fee system in areas of tort litigation, and the emphasis on litigation, as opposed to participation in agency proceedings, such an arrangement might encourage, are obvious shortcomings. A foundation for fee shifting in the absence of statutory authority may have been laid by the Supreme Court's decision in Mills v. Electric Auto-Lite Co. ${ }^{294}$ which awarded attorney's fees as well as costs to the plaintiffs who successfully brought a stockholders' derivative action for the dissemination of misleading proxy statements. ${ }^{295}$ Though the action created no monetary fund, the Court found that the suit "conferred a substantial benefit on the members of an ascertainable class, and . . . an award . . . will operate to spread the costs proportionately among them." 296 Reimbursement of fees for private law enforcement could conceivably be extended to other areas of social concern, such as enforcement of pollution and consumer protection laws. ${ }^{297}$ The vague contours of Mills' benefit rationale, the possibility of numerous, abusive nuisance suits for relatively minor violations of the law, ${ }^{298}$ and the problem of deciding which litigants or participants in an administrative proceeding have in fact conferred a benefit to a segment of the public, may inhibit widespread adoption of the fee-shifting principle. Indeed,

289 See, e.g., Gellhorn, supro note 18, at 389-93.

290 Id. 393-94.

291 See notes 793-99 infra \& accompanying text.

292 See generally Dole, Consumer Class Actions Under Recent Consumer Credit Iegislation, 44 N.Y.U.L. REv. 80 (1969).

293 Lazarus \& Onek, supra note 19 , at $1100-02$; cf. notes $456-70$ infra \& accompanying text.

294396 U.S. 375 (1970).

295 Id. at 390-93. See also Kahan v. Rosenstiel, 424 F.2d 161 (3d Cir. 1970).

296396 U.S. at 393-94.

297 See Comment, The Allocation of Attorney's Fees After Mills v. Electric AutoLite Co., 38 U. CHI. L. REv. 316, 329-30 (1971).

298 See id. 334. 
the Administrative Conference has refused to endorse reimbursement of incurred legal expenses. ${ }^{299}$

The subsidy approach would permit the agency, in its discretion, to reimburse public interest participants for legal and witness fees, ${ }^{300}$ or, in the alternative, to establish within the agency a special office to provide legal assistance to public interest participants. ${ }^{301}$ This approach assumes, of course, that agencies presently possess statutory authority to incur such expenses. ${ }^{302}$ The obvious objections to this suggested approach are that the agency itself passes on the utility of intervention and, under the second alternative, has a great deal of control over how the case will be presented, a factor which would undoubtedly impair a participant's critical perspective.

A third approach would institutionalize public advocacy, and is exemplified by the proposed Public Counsel Corporation. ${ }^{303}$ The bill would have enabled the corporation to

(1) represent, either directly or by contract with appropriate individuals or private organizations, the interests of the unrepresented public and, where appropriate, separate interests of distinct groups within the unrepresented public, in proceedings before regulatory agencies . . . provided that in carrying out its contracting authority under this section, the corporation shall give preference to nonprofit organizations with experience in representing the public interest before Federal agencies;

(2) initiate rulemaking proceedings in any regulatory agency when otherwise authorized ... ;

(3) collect and disseminate to all interested organizations and to the general public information concerning rulemaking . . . ;

(4) represent, upon request, individuals or private organizations who seek judicial review of Federal administive actions .....$^{304}$

299 Administrative Conference of the United States, Recommendation 28, adopted Dec. 7, 1971; see note 18 supra.

300 See Lazarus \& Onek, supra note 19, at 1009-10; cf. note 713 infra \& accompanying text.

301 See note 452 infra \& accompanying text.

302 See Lazarus \& Onek, supra note 19, at 1100.

303 The Public Counsel Corporation was first proposed in 1970 but was never reported out of committee. See Hearings on $S .3434 \& S .2544$ Before the Subcomm. on Administrative Practice \& Procedure of the Senate Comm. on the Judiciary, 91st Cong., 2d Sess. (1970). The proposal was recently reintroduced. See Hearings on S. 1423 Before the Subconnm. on Administrative Practice \& Procedure of the Senate Comm. on the Judiciary, 92d Cong., 1st Sess. (1971). For an earlier recognition of the possibilities of this approach to increasing administrative accountability, see Cahn \& Cahn, supra note 13.

304 S. 3434, 91st Cong., 2d Sess. $\$ 588$ (a) (1970) (referred to the Committee on the Judiciary, Feb. 10, 1970). 
The bill would thus have authorized the establishment of an agency staff which could develop its own expertise, policy, and continuity, while providing, through independent contracts with public interest law firms appearing before agencies and reviewing courts, a measure of insulation from the pressures to conform to the norms of its own bureaucracy. Most important, the corporation would have been enabled to represent a wide variety of interests. ${ }^{305}$

In contrast, the Consumer Protection Act, one verson of which was passed by the House in $1971^{306}$ and another of which is presently under consideration by the Senate, ${ }^{307}$ is much less ambitious. It is directed primarily toward the problems of the consumer and does not in terms embrace the wide spectrum of problems affecting the environment or the poor and minority groups. The bills authorize the employment of expert witnesses ${ }^{308}$ and the appointment of advisory committees, ${ }^{309}$ but do not authorize contracts with public interest law firms to provide independent representation. Though they do not purport to make the CPA the exclusive representative of consumers' interests, neither do they contemplate the direct financing of public interest law firms and kindred organizations, as did the Public Counsel Corporation proposal. The bills provide for the publication and distribution of information of general interest to consumers, ${ }^{310}$ but the general provisions do not ensure any improvement in informing the public of the pendency of specific agency proceedings likely to affect their interests. ${ }^{311}$

At the heart of both bills are the provisions for representation before agencies and courts. In the House bill the agency has authority to participate in, but not to initiate, any rulemaking proceeding other than one "involving solely the internal operations of the Federal agency," 312 and may intervene in, but may not initiate, adjudicatory proceedings "other than an adjudication seeking primarily to impose a fine, penalty, or forfeiture." ${ }^{313}$ This latter prohibition, if read broadly,

305 Lazarus \& Onek, supra note 19, at 1097, suggest that any scheme should be judged in terms of the adequacy of financing, its independence from bureaucratic and industry controls, its accountability to the public, and its expertise.

306117 Cong. Rec. H9583 (daily ed. Oct. 14, 1971) ; see N.Y. Times, Oct. 15, 1971 , at 1 , col. 1 .

307 S. 1177, 92d Cong., 1st Sess. (1971) [hereinafter cited as S. 1177]. See Hearings on S. 1177 \& H.R. 10,835 Before the Subcomm. on Executive Reorganization \& Gov't Research of the Senate Comm. on Gov't Operations, $92 \mathrm{~d}$ Cong., 1st Sess. (1971).

308 H.R. 10,835, 92d Cong., 1st Sess. $\$ 202(\mathrm{~b})(2)$ (1971) [hereinafter cited as H.R. 10,835$]$; S. 1177 \$206(a) (2).

300 H.R. 10,835 §202(b) (3) ; S. 1177 §206(a) (3).

310 H.R. $10,835 \S 206$; S. $1177 \S 205$.

311 See notes 253-55 supra \& accompanying text.

312 H.R. 10,835 $\$ 204$ (a) (1).

313 H.R. 10,835 $\$ 204$ (a) (2). Section 204(e) provides that the CPA may request a federal agency to initiate such proceedings, but there is no obligation on the agency other than to notify the CPA of its reasons for declining to initiate such action; section 204(d) empowers the CPA to initiate or intervene in judicial review. Id. $\$ \$ 204(\mathrm{e})$, (d). The Senate bill, S. $1177 \$ 203(\mathrm{a})$, does not provide for review of failures of the agency to act. 
might foreclose participation in a variety of proceedings affecting consumers' interests: for example, a proceeding resulting in a cease-anddesist order or in a civil penalty. The Senate bill has no analogous section though the limitation appears to be implied. ${ }^{314}$ The Moorhead amendment ${ }^{315}$ to the House bill would have permitted the CPA to participate in such proceedings in the role of consumer advocate, addressing broad issues of policy and the nature of an appropriate civil remedy, but not in the role of a second prosecutor litigating the guilt of a respondent or the nature of a criminal sanction. ${ }^{316}$ The amendment would also have added the following section to the bill:

The Agency, as a matter of right, may undertake reviews and investigations, and require information from Federal agencies .. . for the purpose of submitting information, findings, or recommendations to the Congress regarding any matter affecting the interests of consumers concerning which a Federal agency has the authority but fails to initiate a rulemaking or adjudicatory proceeding . . . . ${ }^{317}$

The CPA would thus have been permitted to duplicate the factfinding functions of rulemaking or adjudicatory proceedings affecting consumer interests which an agency had declined to initiate; the CPA would arguably have the subpoena power which the agency had refused to use in declining to initiate. ${ }^{318}$ The ultimate effect would have been either to force the agency to initiate proceedings or to have the agency's informal procedures subjected to intense scrutiny.

During the course of the House debate, one commentator felt the amendment posed a "risk of grave interference with the functioning and responsibility of Federal agencies." 319 The bewildering variety of informal agency action makes it impossible to define with any particularity what the nature and scope of the CPA's power would have been under the amendment. That power might permit inquiry into virtually every exercise of agency discretion in its informal operations. The defeat of the amendment, however, does not necessarily imply that there should not be a more narrowly defined power on the part of the CPA

314 See Hearings, supra note 307, at 156 (staff comparison of the House \& Senate bills), 11 (statement of Representative Holifield).

315 Amendment offered by Representative Moorhead, 117 CoNG. REc. H9503 (daily ed. Oct. 13, 1971), rejected by the House, 117 CoNG. REc. H9571-72 (daily ed. Oct. $14,1971)$.

316117 Cong. REc. H9503 (daily ed. Oct. 13, 1971). One commentator thought the original language conveyed the same intent. Letter from Roger C. Cramton, Chairman of the Administrative Conference of the United States, to Representative Holifield, in 117 CoNG. REC. H9484-85 (daily ed. Oct. 13, 1971).

317117 CoNG. REc. H9503 (daily ed. Oct. 13, 1971).

318 The Senate bill, S. $1177 \S 205$ (d), provides for greater subpoena power. See Hearings, supra note 307, at 10 (statement of Representative Holifield).

319 Cramton, supra note 316 , at H9485. See Kilpatrick, Coming Up: Super Consumer Agency, Evening Bulletin (Philadelphia), Mar. 25, 1972, at 10, col. 2; cf. Consumer Reports, Feb. 1971, at 80. 
to investigate, and perhaps initiate review of, certain classes of informal agency action. That power might, for example, extend to FTC consent orders or approvals of mergers potentially affecting consumers, or to agency prosecutorial discretion in similar areas. The intervention section of the Senate bill provides for easier access to agency proceedings than the House bill. ${ }^{320}$ The bill passed by the House gives the CPA essentially no greater right to intervene in or initiate formal agency action than that of private parties. ${ }^{321}$ As a practical matter, an agency might be less likely to limit the procedural privileges allowed the CPA as intervenor, although the agency might feel more justified in denying such privileges to a public interest group intervening independently in the same proceeding. The CPA, which is Congress' most adventurous attempt to date to facilitate the representation of unrepresented interests, makes no provision for the public financing needed by public interest groups to participate effectively, and in some instances may, paradoxically, tempt agencies to limit the scope of their participation.

Congressional reliance upon independent agencies like the CPA to achieve the objective of broadened public participation, without supplemental support for independent public interest groups, may mean that the latter will not advance beyond their present state of effectiveness. They are assured by Welfare Rights the opportunity to intervene to the extent necessary to make the expanded right of review under Data Processing effective, but are as yet in desperate need of financial support to enable them to use that opportunity to the fullest.

\section{An Analysis of Five Agencies' Expertence with Public Participation}

\section{A. Federal Communications Commission}

The primary responsibility of the Federal Communications Commission (FCC) is the regulation of communications common carriers ${ }^{322}$ and broadcasting services. ${ }^{323}$ Demands for public participation are currently being pressed with most frequency and zeal in proceedings involving the renewal of broadcasting licenses. Several reasons may explain this focus: the initial licensing of the more profitable segments of the radio spectrum allocated to radio and television broadcasting has

320 Compare S. 1177 \$203 with H.R. 10,835 \$204. See Hearings, supra note 307, at 155 (staff comparison of the 2 bills), 160 (discussion by Representative Rosenthal of differences between the bills).

321 While the House bill may be less intrusive in this respect, it does provide broad authority for the CPA to initiate judicial review, whether or not the CPA was a party to the proceedings below. H.R. 10,835 $\$ 204$ (d). The Senate bill allows the CPA to initiate judicial review only if it intervened in the agency proceeding. S. 1177 $\$ 203$ (d). See Hearings, supra note 307, at 224 (statement of Roger C. Cramton).

32247 U.S.C. $\$ \$ 201-23(1970)$.

323 Id. $\$ \$ 301-99$. 
been substantially completed, ${ }^{324}$ the licenses must be renewed at threeyear intervals, ${ }^{325}$ and the rules covering contested renewals provide opportunity for the public to express its dissatisfaction with a licensee's previous performance ${ }^{326}$ and, in many cases, to obtain judicial review of adverse agency determination. ${ }^{327}$

A renewal hearing is a serious and costly affair for all concerned, ${ }^{328}$ but one to which only a minute percentage of broadcast licenses are now subjected. ${ }^{329}$ Even though a broadcast license is a privilege ${ }^{330}$ and a public trust subject to revocation, ${ }^{331}$ creating no right "beyond the terms, conditions, and periods of the license," ${ }^{332}$ the broadcast industry regards the failure to renew with terror, calling it a "death sentence." " 333 The FCC itself has viewed the refusal to renew as the "supreme penalty, one which by custom has been reserved for transgressors whose acts of disobedience or folly have reached major dimensions." 334 There are, of course, statutory rules ${ }^{\mathbf{3 3 5}}$ and overtones of

324 At the close of fiscal year 1970, only 82 commercial AM, 134 commercial FM and 129 commercial television (UHF \& VHF) frequencies still were available. See 36 FCC ANN. REP. 144-46 (1970). Since July 1968, however, the Commission has refused to accept applications for new AM radio stations. Id. 42 . Of the available FM licenses, most are for low power class A stations which are commercially less desirable than the higher powered class $B$ and $C$ stations, which have greater coverage and can therefore demand higher advertising revenues. See $i d$. 43-44. "In many parts of the country . . . only the class A channels in the smaller cities remain." Id. 44. Of the remaining television frequencies, the bulk are in the less profitable UHF band. See id. 41,159 .

32547 U.S.C. $\$ 307$ (d) (1970) ; see 47 C.F.R. $\$ \S 73.34$, .218 (1971). In contrast, the FPC may, for example, grant licenses for terms of up to 50 years. See note 725 infra \& accompanying text.

326 See notes 343-400 infra \& accompanying text.

327 Id.

328 See note 466 infra.

329 In 1967, 6 applications for renewal were designated for hearing $(0.24 \%$ of all applications renewed); in $1968,15(0.51 \%)$; in $1969,17(0.62 \%)$. Comment, Public Participation in License Renewals and the Public Interest Standard of the FCC, 1970 UTAF L. REv. 461, $463 \mathrm{n} .21$. In fiscal 1970, 18 renewal applications were designated for hearing ( $0.68 \%$ of all applications renewed). 36 FCC ANN. REP. 147-48 (1970). About 7700 licenses are renewed every three years. Compare id. 2 with Johnson, $A$ New Fidelity to the Regulatory Ideal, 59 GEo. L.J. 869, 879 (1971).

330 Television licensees recover during their three-year terms an average of from $200 \%$ to about $600 \%$ of their investment. Fenton, The Federal Communications Commission and the License Renewal Process, 5 Sufrolk U.L. Rev. 389, 414 (1971).

331 See Office of Communication of the United Church of Christ v. FCC, 359 F.2d 994, 1003 (D.C. Cir. 1966).

33247 U.S.C. $\$ 301$ (1970); see Ashbacker Radio Corp. v. FCC, 326 U.S. 327 331-32 \& n.6 (1945); accord, FCC v. Sanders Bros. Radio Station, 309 U.S. 470,475 (1940). In fact, no license will be granted until the applicant has signed a waiver of claim to a frequency "because of the previous use of the same." 47 U.S.C. $\$ 304$ (1970).

333 See D. Gitlmor \& J. Barron, Mass Communication Law 711 (1969). 334 Brandywine-Main Line Radio, Inc., 24 F.C.C.2d 18, 26 (1970) ; cf. Comment, The Fairness Doctrine and Broadcast License Renewals: Brandywine-Main Line Radio, Inc., 71 Colum. L. Rev. 452, 458 (1971).

335 See Administrative Procedure Act $\S 9$ (c), 5 U.S.C. $\$ 558(c)$ (1970); 47 U.S.C. $\$ 402$ (a) (1970) (applying the APA to certain FCC appeals); cf. id. $\$ \$ 312$ (c) - (e) (requirements of serving of order to show cause, hearing, burden of proof on Commission, and application of APA in license revocation proceedings). 
due process protections in the background ${ }^{336}$ suggesting that the refusal to grant another license to an incumbent broadcaster cuts much closer to the line of a deprivation of property than the denial of a privilege associated with the initial licensing proceeding.

The determination whether to renew normally focuses on the licensee's performance during the preceding license period. ${ }^{337}$ Although the showing required to warrant renewal is unsettled, ${ }^{338}$ members of the public within the area served by the licensee are in a particularly good position to contribute to any inquiry into that history. ${ }^{339}$ The public is faced with the relatively narrow questions of programming desires and preferences and their allocation within the limits of an established number of available frequencies. ${ }^{340}$ Broader questions concerning, for example, the structure of the broadcasting industry, the impact of the size, technological operation, and placement of facilities on the social, economic, and ecological systems, and the economical use of the total radio band, have either been resolved by arrangement with

336 See Reich, Individual Rights and Social Welfare: The Energing Legal Issues, 74 Yat. L.J. 1245, 1255 (1965). See also $1 \mathrm{~K}$. Davis, supra note $23, \$ 7.18$, at 495-97.

337 See, e.g., Office of Communication of the United Church of Christ v. FCC, 359 F.2d 994, 1007 (D.C. Cir. 1966); cf. W. EMERX, BroadCASTING AND GoverNMENT: RESPONSIBILITIES AND REGULATIONS 246 (1971).

338 The controversy over this issue and the consequent congressional reexamination of both the Commission's renewal process and substantive criteria for renewal have been precipitated chiefly by the Commission's first decision not to renew the license of a broadcaster whose performance was judged only "average" and to award the frequency to a challenger. WHDH, Inc., 16 F.C.C.2d 1 (1969), aff'd sub nom. Greater Boston Television Corp. v. FCC, 444 F.2d 841 (D.C. Cir.), cert. denied, 402 U.S. 923 (1971). For reaction to WHDH, see S. 2004, 91st Cong., 1st Sess. (1969) ; Goldin, "Spare the Golden Goose"-The Aftermath of WHDH in FCC License Renewal Policy, 83 HaRv. I. REv. 1014 (1970); Jaffe, WHDH: The FCC and Broadcasting License Renewals, 82 HARv. L. Rev. 1693 (1969); Comment, The Aftermath of WHDH: Regulation by Competition or Protection of Mediocrity?, 118 U. PA. L. Rev. 368 (1970); 20 CATH. U.L. REv. 328 (1970).

The Commission's Policy Statement Concerning Comparative Hearings Involving Regular Renewal Applicants, 22 F.C.C.2d 424 (1970), which conferred upon an incumbent licensee a controlling preference over another applicant by showing past performance substantially serving the public, was successfully attacked by the Citizens Communications Center and Black Efforts for Soul in Television (BEST). Citizens Communications Center v. FCC, 447 F.2d 1201 (D.C. Cir. 1971). The Policy Statement had "served to deter the filing of a single competing application for a television renewal in over a year ...."Id. at 1206; see Comment, Implications of Citizens Communications Center v. FCC, 71 Colun. L. REv. 1500 (1971). The groups had earlier petitioned for rulemaking proceedings for comparative broadcast hearings. BEST, 21 F.C.C.2d 355 (1970). But see Moline Television Corp., 31 F.C.C.2d 263 (1971), appeal docketed sib nom. Community Telecasting Corp. v. FCC, No. 71-1741, D.C. Cir., Sept. 17, 1971 (Commission gave preference in a comparative hearing to an incumbent whose performance was inferior to its past promises, and renewed its license). The decision, characterized by Commissioner Johnson 25 "lawless," id. at 277 , was reported as "being read by legal specialists . . as evidence that the F.C.C.'s Republican majority will tend to favor incumbent broadcasters against their rivals." N.Y. Times, Aug. 24,1971 , at 75, col. 4.

339 It has been observed, however, that "recognizing the standing of members of the broadcasting audience to challenge renewal applications will not further the judicial policy of encouraging meaningful public participation in the renewal process if the Commission at the same time refused to re-evaluate its broadcasting standards" or leaves the public unapprised of licensing criteria. Comment, supra note 329 , at 465 .

340 See 47 C.F.R. $\$ \S 73.21-.29, .202, .203, .606, .607$ (1971); cf. id. $\$ 2.106$. 
other governmental bodies, ${ }^{341}$ been determined through rulemaking proceedings, ${ }^{342}$ or not been perceived as problems by anyone with opportunity and sufficient concern to raise them.

\section{Standing Before the FCC}

Broadcast licenses may be granted or renewed only if the Commission finds that "the public interest, convenience, and necessity would be served." 343 Anyone may file a petition to deny a license or license renewal, which "petition shall contain specific allegations of fact sufficient to show that the petitioner is a party in interest and that a grant of the application would be prima facie inconsistent with" the public interest, convenience, and necessity. ${ }^{344}$ If the petition to deny presents a "substantial and material question of fact," or if the Commission is unable to find affirmatively that grant of the application would serve the public interest, ${ }^{345}$ the Commission "shall formally designate the application for hearing." " 346 Those who file petitions raising such questions and satisfy the "party in interest" requirement may participate as full parties to the hearing; ${ }^{347}$ other persons "may file a petition for leave to intervene," and, on a showing of the requisite interest and of the contribution the petitioner will make to the determination of the issues, may become parties to the proceeding. ${ }^{348}$ Furthermore, "[n]o person shall be precluded from giving any relevant, material, and competent testimony at a hearing because he lacks a sufficient interest to justify his intervention as a party in the matter." ${ }^{449}$

341 For example, the control of government-owned-and-operated stations rests in the President, 47 U.S.C. $\$ 305$ (a) (1970), who has delegated that function to the Office of Telecommunications Policy (OTP), see Exec. Order No. 11,556, 3 C.F.R. 548 (1971), 47 U.S.C. $\$ 305$ (1970); Reorganization Plan No. 1 of 1970, 6 WeEkLY CoMP. PRES. DoC. 156 (1970), 47 U.S.C. $\$ 305$ (1970); cf. 3 U.S.C. $\$ 301$ (1970). The OTP coordinates its functions with the FCC and the Interdepartmental Radio Advisory Committee, which is "composed of representatives of those Federal agencies making extensive use of radio." 36 FCC ANN. REP. 112 (1970); see 1971/72 U.S. GovernNent ORganization MaNuaI 556-57 (1971); cf. 47 C.F.R. \$0.37 (1971).

In the area of deceptive advertising, the Communications and Trade Commissions have maintained an arrangement since 1957 "whereby the FTC will advise the FCC of questionable advertising broadcast over radio and television stations." Liaison Between FCC \& FTC Relating to False \& Misleading Radio \& TV Advertising, 22 F.C.C. 1572 (1957). For subsequent FCC-FTC agreements, see [CURRENT SERVICE] P \& F Ranio Reg. III 11:401, :402 (1971); cf. W. EMERY, sulpra note 337, at 72-82.

342 See, e.g., note 340 supra.

34347 U.S.C. $\$ 309$ (a) (1970).

344 Id. $\$ 309$ (d) (1).

$345 I d . \$ \& 309$ (d) (2), (e).

346 Id. $\$ 309(\mathrm{e})$.

34747 C.F.R. \$1.223(a) (1971). See American Communications Ass'n v. United States, 298 F.2d 648 (2d Cir. 1962) (interlocutory review and reversal of denial of intervention by a trade union whose status as a party in interest was conceded, but deemed by the Commission not useful).

34847 C.F.R. \$1.223(b) (1971).

349 Id. \$ 1.225 (b). Less formal channels for public participation are also available. "[A]ny person" may submit "informal objections" to the grant, renewal, or assignment of a license, $i d$. $\S 1.587$, and, during a license term, informal requests for Com- 
The evolution of the rule that one show that he has an interest, while not consistent, has been toward complete obliteration of the requirement. Before enactment of section 309 (c), the precursor of the present petition-to-deny section, the Federal Communications Act contained no provision covering intervention. ${ }^{350}$ By the time the section was added, the Supreme Court had handed down a germinal case on standing to appeal from administrative decisions. FCC v. Sanders Brothers Radio Station ${ }^{351}$ allowed standing to a competitor facing a direct economic injury by the grant of a license, even though that interest was not one the agency could have considered in refusing to grant a license. ${ }^{352}$ The concept of such a "private attorney general" ${ }^{353}$ was founded on the rationale that a plaintiff willing to challenge the agency's effectuation of its statutory mandate, and having sufficient economic stake in the outcome to litigate seriously, served a useful function by supplementing the Commission's resources. ${ }^{354}$ As has been discussed earlier, ${ }^{355}$ this concept has been instrumental in greatly broadening the scope of judicial review over agency decisionmaking.

When enacted in 1952, ${ }^{356}$ section 309(c)'s "party in interest" phrase was intended to authorize intervention in FCC proceedings only to the extent allowed by the Sanders decision for appeals from agency decisions. ${ }^{357}$ As late as 1959 it was possible for one student commentator, by logically extending the Sanders rationale to include situations in which the intervenor could provide useful factual data for the Commission, ${ }^{358}$ to criticize expansion of the term to include "secondary" competitors as being unsupported by equity, redundant, because primary competitors might be found, and unjustifiably burdensome on Commission resources. ${ }^{359}$ Today, however, the interest requirement as

mission action may be submitted, id. $\$ 1.41$. See, e.g. Friends of the Earth, 24 F.C.C.2d 743 (1970), rev'd, 449 F.2d 1164 (D.C. Cir. 1971) (fairness doctrine complaint on automobile pollution); San Francisco Women for Peace, 24 F.C.C.2d 156 (1970), aff'd sub nom. Green v. FCC, 447 F.2d 323 (D.C. Cir. 1971) (fairness-doctrine complaints on military recruitment) ; Boalt Hall Student Ass'n, 25 F.C.C.2d 70 (1969) (fairness-doctrine complaint on governor's speech). The fairness doctrine of the FCC ensures "reasonable opportunity for discussion of conflicting views on issues of public importance." Citizens Communication Center, Primer on Citizens' Access

to the Federal Communications Commission 4 (1971 draft).

350 Communications Act of 1934, ch. 652, §309, 48 Stat. 1085. See 107 U. PA.

L. REv. 551, 552 (1959). See note 405 infra.

351309 U.S. 470 (1940).

$352 I d$. at 476 .

353 The precise phrase, however, was subsequently coined by Judge Frank in Associated Indus., Inc. v. Ickes, 134 F.2d 694, 704 (2d Cir.), vacated as moot, 320 U.S. 707 (1943).

354107 U. PA. I. REV. 551, 556 (1959) ; see 309 U.S. at 477.

355 See notes 53-54 supra \& accompanying text.

356 Act of July 16, 1952, ch. $879, \$ 7(\mathrm{e}), 66$ Stat. 715.

357 S. Rep. No. $44,82 d$ Cong., 1st Sess. 8 (1951).

358 Sanders itself, however, spoke only to the proposition of presenting errors of law to appellate courts. See 309 U.S. at 477.

359 See 107 U. PA. L. Rev. 551, 556-59 (1959). 
interpreted by the courts ${ }^{360}$ is so weak that knowledgeable commentators have felt free to state simply that a complaining party who is responsible for initiating the hearing process with a petition to deny alleging material issues, "usually has a substantial stake in the proceeding and may be able to make a contribution," ${ }^{361}$ which distinguishes him from the public at large. ${ }^{362}$

In 1965 , a petition to deny the renewal application of television station WLBT in Jackson, Mississippi, was filed by the Office of Communications of the United Church of Christ, a "national denomination, with churches and members in . . . the prime service area covered by WLBT," ${ }^{363}$ the local congregation of the church, and two Mississippi civil rights leaders, asserting that "the station failed to present programing designed to serve the particular needs and interests of the Negro Community" and did not "give a fair presentation of the issues." ${ }^{364}$ The Commission denied standing to the petitioners, following its established doctrine that

members of the general public who do not show a direct causal relationship between the action being protested and some injury of a tangible and substantial nature have no standing purely as members of the general public. ${ }^{365}$

The FCC reasoned that minority groups had "no greater interest or claim of injury than the general public," otherwise "any minority group based on race, creed, color, or national origins could gain standing as a representative of the public interest." ${ }^{366}$ The United Church of Christ was therefore not a party in interest within the meaning of section 309 (d) (1)..$^{367}$

On appeal, the Court of Appeals for the District of Columbia Circuit, in its landmark United Church of Christ decision, ${ }^{368}$ disagreed and reversed. The court could see no reason to exclude the listening public, those "most directly concerned with and intimately affected by the performance of a licensee," ${ }^{369}$ from the renewal process. Indeed, public spokesmen might be the only source from which the Commission could learn of programming deficiencies or other objectionable prac-

360 See text accompanying notes 377-95 infra.

361 Shapiro, supra note 37 , at 728.

362 Cf. Gellhorn, supra note 18 , at 380 .

363 Lamar Life Broadcasting Co., 38 F.C.C. 1143, 1143 n.1 (1965).

364 Id. at 1148.

365 Id. at 1149 n.11.

$366 I d$. (emphasis in the original).

367 See note 344 supra \& accompanying text. The Commission did, however, consider the allegations of the Church as set forth in the petition to deny "irrespective of any question of standing or related matters." 38 F.C.C. at 1149.

368 Office of Communication of the United Church of Christ v. FCC, 359 F.2d 994 (D.C. Cir. 1966).

369 Id. at 1002. 
tices. $^{370}$ The court chastised the Commission for rigidly allowing standing to intervene only to those alleging electrical interference or direct economic injury ${ }^{371}$ and for discounting the efficacy of consumer participation. ${ }^{372}$

The theory that the Commission can always effectively represent the listener interests in a renewal proceeding without the aid and participation of legitimate listener representatives fulfilling the role of private attorneys general is one of those assumptions we collectively try to work with so long as they are reasonably adequate. When it becomes clear, as it does to us now, that it is no longer a valid assumption which stands up under the realities of actual experience, neither we nor the Commission can continue to rely on it. The gradual expansion and evolution of concepts of standing in administrative law attests that experience rather than logic or fixed rules has been accepted as the guide..$^{373}$

The court held that "some 'audience participation' must be allowed in license renewal proceedings," 374 and remanded the case to the Commission for a hearing, directing that "one or more" of the appellants be granted standing "as responsible representatives." ${ }^{375}$ The court suggested that the Commission develop standards to determine which community representatives should participate and how that participation could best be effectuated. . $^{376}$

While the development of standing to intervene in FCC proceedings was left by Congress to the agency and, by virtue of the rules of standing to appeal, the courts, ${ }^{377}$ further judicial pronouncements on

370 Id. at 1004-05.

371 Id. at 1000-02. See 107 U. PA. L. Rev. 551, 555-56 (1959).

372359 F.2d at 1004 .

373 Id. at 1003-04.

$374 I d$. at 1005.

375 Id. at 1006 . On remand, standing was granted to all 4 petitioners. The Commission expressed a preference for organizations rather than individuals, granting the individual petitioners standing only because they were represented by the same counsel as the Church. Lamar Life Broadcasting Co., 3 F.C.C.2d 784, 786 (1966).

376359 F.2d at 1005-06. For further discussion of the principal case, as well as commentary on the development of FCC standing prior to 1966, see Keller, The Laze of Administrative Standing and the Public Right of Intervention, 21 FED. Conr. B.J. 134 (1967); Comment, Standing of Television Viewers to Contest FCC Orders: The Private Action Goes Public, 66 Colum. L. Rev. 1511 (1966); Note, 13 Wayne L. REv. 377 (1967).

377359 F.2d at 1001-02; Comment, supra note 376 , at 1519 \& n.52. (The note discusses the legislative history of the Federal Communications Act and notes that it is silent as to the meaning of the phrase "parties in interest." The commentator concludes, however, on the basis of this silence alone, that the development of standing was left to the federal courts.) Courts will not, of course, hear the appeal of one who failed to exhaust administrative remedies as, for example, by failing to seek party status before the agency or by failing to seek a rehearing, regardless of standing claims or requests for meritorious substantive relief. See Joseph v. FCC, 404 F.2d 207, 209 (D.C. Cir. 1968) ; 47 U.S.C. $\$ 405$ (1970). 
the subject have been rare, but have effectively removed viable requirements for standing from the agency's arsenal for the control of hearings. In Joseph v. FCC, ${ }^{378}$ the court upheld an individual listener's standing to challenge the assignment of a Chicago fine arts station ${ }^{379}$ "as a representative of the listening public." ${ }^{380}$ Hale v. $F C C,{ }^{381}$ while not squarely facing the standing issue, lends further support to the granting of intervention to individuals. The Commission avoided the question of the standing of two individuals who were protesting the proposed license renewal of station KSL, Salt Lake City, Utah. The petitioners charged that the station was part of an undue concentration of communications media and was furthering only its own economic and ideological interests in its programming. ${ }^{382}$ The FCC suggested that, under United Church of Christ, "petitioners must have a legitimate interest in the proceedings, by showing that they are responsible representatives of groups representative of the listening public, rather than speaking for only individuals." ${ }^{83}$ While the agency found that "substantial procedural issues" were raised, it decided not to pursue them as the case could be disposed of on the merits without a hearing. ${ }^{384}$ Commissioner Johnson's dissent strongly rejected the majority's intimation that only formal organizations could be responsible representatives of the public:

Surely there are few people who do not recognize the ease by which paper groups can be organized around a few activists. But does this Commission really intend to sacrifice the public interest on the altar of such hollow legalism? ${ }^{385}$

378404 F.2d 207 (D.C. Cir. 1968).

379 "No . . . station license . . shall be . . assigned . . . except . . . upon [a] finding by the Commission that the public interest, convenience, and necessity will be served thereby." 47 U.S.C. \$310(b) (1970). The Citizen's Committee to Save WFMT (FM) also challenged the assignment, but since the Committee had not taken any action before the FCC, the court held that it had not exhausted administrative remedies and therefore the court could only consider the individual challenger's contentions. 404 F.2d at $209 \&$ n.4.

380404 F.2d at 210. The court cited United Church of Christ for the proposition that " $[t]$ he allegations in the motion . . demonstrated at least prima facie standing." $I d$. at 211 . Referring to the argument that the petitioner failed to move for reconsideration as a prerequisite for judicial review, the court reasoned that petitioner's motion for intervention, which was evidently considered after the initial decision, served the purpose of the condition for review, especially as a "representative of the listening public" usually "[does] not have the same sort of Washington representation to uncover threats to their interest, or deploy apparatus to combat them, as do parties whose interest is economic." Id. at 210 . The decision has been criticized as "[overlooking] administrative requirements in order to reach the merits in an appealing case," 57 GEO. L.J. 631, 639 (1969), but should properly be praised, as refusing to insulate the Commission from judicial review because of relatively minor procedural barriers.

381425 F.2d 556 (D.C. Cir. 1970).

382 KSL, Inc., 16 F.C.C.2d 340, 344 (1969); see ReSponses, supra note 30, at 61. 38316 F.C.C.2d at 344.

384 Id.

385 Id. at 349. 
On appeal, ${ }^{386}$ the court apparently agreed with Commissioner Johnson, noting that

[KSL], but not the Commission, urges upon this appeal that appellants are without standing to complain, either before the Commission or in this court, of the license renewal. We think the Commission's position here reflects the more prescient reading of our opinion in [United Church of Christ]. . $^{387}$

The court found, however, that the petitioner's generalized complaint about unfair programming and concentration of media control was more appropriate for rulemaking and that the Commission was undertaking a review of its policies concerning those issues. ${ }^{385}$

There may remain a rudimentary requirement of interest, but any hypothetical function it might serve in ensuring that a party litigate either well or energetically is doubtful. In Martin-Trigona v. FCC, ${ }^{389}$ the court denied a petition to review the Commission's denial of standing to an Urbana, Illinois, resident who had challenged the renewal of the licenses of the three major television networks' New York "flagship" stations. The FCC had determined that petitioner's complaints about excessive commercialization should have been directed at the local stations in his area rather than at the New York network stations. ${ }^{390}$ The court, questioning " $[\mathrm{w}]$ hether the matter is best approached analytically in traditional standing terms," dismissed on the merits without attempting to formulate standards for intervention before the FCC. ${ }^{391}$ Citing Hale, the court said that petitioner's concerns raised broad policy issues more pertinent to the broadcasting industry as a whole than to the renewal of the individual licenses and were therefore more appropriately explored in rulemaking. ${ }^{302}$ MartinTrigona also challenged the renewal of station WRC-TV in Washing-

386 Appeals from decisions and orders of the FCC may be taken to the Court of Appeals for the District of Columbia Circtit "by any ... person who is aggrieved or whose interests are adversely affected . . " 47 U.S.C. $\$ 402(\mathrm{~b})(6)$ (1970). Intervention in an appealed case is limited to "any interested person," defined as "[a]ny person who would be aggrieved or whose interest would be adversely affected by a reversal or modification of the [FCC] order..." Id. $\$ 402(\mathrm{e})$. That the same standard is applied to determine a "party in interest" for standing purposes before both Commission and court is supported by the courts and legislative history. Comment, supra note 377 , at 1514 n.18. The reason is to allow persons who have a right to challenge FCC orders in court to first present their claims before the Commission. Id.; cf. Office of Communication of United Church of Christ v. FCC, 359 F.2d 994, 1000 n.s (D.C. Cir. 1966).

387 Hale v. FCC, 425 F.2d 556, 558 n.2 (D.C. Cir. 1970).

388 Id. at 560 .

389432 F.2d 682 (D.C. Cir. 1970).

390 National Broadcasting Co., 20 F.C.C.2d 58, 59 (1969).

391 Martin-Trigona v. FCC, 432 F.2d 682, 683 (D.C. Cir. 1970).

392 Id. 
ton, D.C., ${ }^{393}$ and petitioned for the revocation of the licenses of all Metromedia television stations. ${ }^{394}$ Twice again he was denied standing. In the latter case, the Commission spoke of "viewer status" conferred by United Church of Christ but found "no decision extending 'viewer' standing to a non-resident transient who may occasionally watch a television station in a community he visits." ${ }^{395}$ The negative pregnant implicit in this statement is that responsible resident non-transient individuals may have standing to intervene.

Sheer aggregation of individuals without more, it should be noted, may not guarantee standing. A short time after Martin-Trigona, the Commission, while examining the questions raised in a petition to deny the assignment of the licenses of WCTW-AM and WCTW-FM, New Castle, Indiana, denied the standing of "a former corporate applicant, composed of over 100 citizens of New Castle, Indiana, representing a cross-section of community leaders," ${ }^{396}$ saying in a footnote:

The fact that Petitioner is a former applicant does not entitle it to standing and the mere fact that over 100 citizens may be involved does not entitle it to standing. ${ }^{397}$

Petitioner, which filed in its corporate capacity, did not oppose the assignment because it objected to programming changes; its goal was the acquisition of a frequency for its own economic gain. 398 The line is a close one, however, but neither Commissioner Johnson's "paper groups" nor the individuals representing them appear to be having difficulty obtaining standing by alleging that they represent a "substantial portion of the listening audience." 389

It seems doubtful that any person or organization wishing to contest a license renewal could fail to find someone within the licensee's broadcast area willing to be represented so long as he is not required to bear the cost of the participation. Martin-Trigona, one is inclined to suspect, could have so presented himself to the Commission, and thus defeated the application of the standing requirement. ${ }^{400}$ Even if not

393 National Broadcasting Co., 20 F.C.C.2d 167 (1969).

394 Petition of Anthony Martin-Trigona, 18 P \& F Radro Reg. 2D 581 (1970). The Commission is authorized to revoke any station license "because of conditions ... which would warrant it in refusing to grant a license ... on an original application . . . 47 U.S.C. \$312(a) (2) (1970).

395 Petition of Anthony Martin-Trigona, 18 P \& F Radro Reg. 2d 581, 582 n.1 (1970).

396 WCTW, Inc., 26 F.C.C.2d 268, 269 (1970).

397 Id. at 269 n.2.

398 See $i d$. at 269.

399 Radio Station WSNT, Inc., 27 F.C.C.2d 993 (1971) (standing granted to 2 petitioners as individuals and as agents of organizations that "represent the interest of a substantial portion of the listening audience of WSNT" and that have "significant roots in the community," upon a showing of individual residency in the community); see Brandywine-Main Line Radio, Inc., 24 F.C.C.2d 18 (1970).

400 Alternatively, it may have been possible to allege that the major networks, which control a disproportionate share of the television market, see Variety, Sept. 15,1971 , at 29 , cols. $1-5$, so affected local programming as to provide a basis for standing. 
dead, standing to intervene based on a requirement of an "interest" is both easily defeated as a barrier and useless as a means for assuring either a responsible or an energetic litigator. "Responsibility" is a loaded term, as Judge Burger must have realized in United Church of Christ, and energy or effort is supplied by the litigator, not the nonpaying "party-in-interest."

\section{The Discretionary Hearing}

Had Martin-Trigona met the Commission's standing requirements, the court nevertheless would have supported the denial of the hearing he requested, and on grounds which have replaced the use of standing as a control of the major cost factor-whether to hold, rather than how extensive to make, a hearing. Limiting the total number of renewal hearings is both one of the Commission's most powerful tools for allocating its scarce resources efficiently and one of the tightest constraints on wider and more piercing examination of licensee practices. Fewer than one percent of renewal applications now go to hearing, ${ }^{401}$ and a hearing is a condition precedent under statute to the denial of renewal. ${ }^{402}$ As has been shown, the FCC has where possible rested denials on the lack of an "interest," a term the courts have now emasculated with the effect of opening completely the class of parties and thus the kinds of issues likely to be raised. ${ }^{403}$ The courts have been quicker than the Commission to perceive that control of the number of hearings must now be accomplished under the other allegation required of a petition to deny-a substantial and material question of fact raising a prima facie case that immediate grant of an application for renewal would not serve the public interest, convenience, and necessity. ${ }^{404}$ This limitation on a petitioner's ability to initiate a hearing was deliberately added to the Federal Communications Act by Congress to give the Commission the "authority to curb the abuses of the protest procedure through the power, in appropriate cases, to dispose of protests without holding a full evidentiary hearing." 405 The requirements of substantiality and

401 See note 329 silpra.

40247 U.S.C. $\$ 309$ (e) (1970).

403 Petitioners still must allege facts with sufficient specificity to substantiate that they are parties in interest. 47 U.S.C. $\$ 309$ (d) (1) (1970). This requirement leaves some discretion in the Commission to verify that status. See NBC v. FCC, 362 F.2d 946 (D.C. Cir. 1966) ; Vermont New York Television, Inc., 6 F.C.C.2d 830 (1967).

40447 U.S.C. $\$ \$ 309$ (d) (2), (e) (1970).

405 S. REP. No. 1231, 84th Cong., 1st Sess. 3 (1955). The protest procedure, operative when the Commission granted an application without a hearing, was first enacted in 1952. Act of July 16, 1952, ch. 879, \$7, 66 Stat. 715. In 1956 the protest procedure was amended to eliminate hearings where only inconsequential facts were alleged, but the Commission was required to find affirmatively that the public interest demanded a grant of a license. Act of Jan. 20, 1956, ch. 1, 70 Stat. 3. In 1960 the pre-grant procedure was changed to its present form. Act of Sept. 13, 1960, Pub. L. No. $86-752, \S 4,74$ Stat. 889 . The legislative history provides nothing but a tautologi- 
materiality obviously refer to the seriousness and relevancy of disputed factual allegations that should be resolved by full inquiry, but the content of those terms is as variegated as the number of possible factual situations. Alleged violations of Commission rules or standards would seem to establish materiality, but whether or not a hearing is compelled usually depends upon the quality of the accompanying facts. ${ }^{406}$ Whether alleged facts sufficiently meet the legal standards so as to make a hearing necessary would appear to be a mixed question of fact and law. As such, the standards of judicial review have been inconsistently applied. ${ }^{407}$ Courts reviewing summary dispositions have ordered hearings where the licensee's alleged past performance would preclude renewal as a matter of law, ${ }^{408}$ where the Commission failed to substantiate its action with affirmative findings that the public interest, convenience, and necessity would be served, ${ }^{409}$ where the courts have ruled that the Commis-

cal explication of the standards implied by the language "substantial and material questions of fact" or "consistent with" the public interest, convenience, and necessity, See H.R. Rep. No. 1800, 86th Cong., 2d Sess. (1960) ; S. ReP. No. 690, 86th Cong., 1st Sess. (1959).

406 Compare Louisiana Television Broadcasting Corp. v. FCC, 347 F.2d 808 (D.C. Cir. 1965), with Andy Valley Broadcasting System, Inc., 12 F.C.C.2d 3 (1968), and WGN of Colorado, Inc., 31 F.C.C.2d 413 (1971). Compare Retail Store Employees Local 880 v. FCC, 436 F.2d 248 (D.C. Cir. 1970), with Anti-Defamation League of B'nai B'rith v. FCC, 403 F.2d 169 (D.C. Cir. 1968), cert. denied, 394 U.S. 930 (1969). Compare Brandywine-Main Line Radio, Inc., 24 F.C.C.2d 18 (1970), with Taft Broadcasting Co., 8 F.C.C.2d 19 (1967). There is a possibility that the Commission will soon be forced to articulate more precisely the standards incorporated in the term. See Brief for Appellee, Stone v. FCC, appeal docketed, No. 71-1166, D.C. Cir., Mar. 8, 1971 (argued Feb. 25, 1972), appeal from Evening Star Broadcasting Co., 27 F.C.C.2d 316 (1971).

Compliance with Commission regulations would appear to immunize a renewal applicant from the threat of a hearing. See Midwest Television, Inc., 17 F.C.C.2d 739 (1969). Allegations in a petition to deny of matters outside the jurisdictional ambit of the Commission's authority cannot be grounds to compel a hearing. See Black Identity Educ. Ass'n, 21 P \& F RAdio REG. 2D 746 (1971).

$4074 \mathrm{~K}$. DAvis, supra note $23, \S 30.07$. Professor Davis has advocated that courts use a practical approach to determine whether agency decisions of mixed law or statutory interpretation and fact should be reviewed with a "rational basis" test or a stricter "substitution of judicial judgment" standard. Id. \$§ 30.03-.06. Davis views the discretion to choose between the two tests as being influenced by a number of unarticulated considerations, including the court's attitude toward the agency, the degree of thoroughness and impartiality of the agency's performance, the importance of the subject matter, and the comparative qualifications of the court and the agency to decide the issue. Id. $\$ 30.14$. Professor Jaffe, on the other hand, would limit the judicial power to review incidental agency lawmaking where there is a statutory purpose to confer upon the agency a policymaking function. L. JAFFE, supra note 33, at 573. Professor Jaffe, examining judicial review of FCC procedural decisions, has criticized the extent to which courts have substituted their judgment for the Commission's in instances where license applications have been granted, despite protests, without a hearing. "Whether the allegations present a matter upon which the Commission should expend its resources is par excellence a matter for the Commission, subject to review only for error of law or a grossly mistaken judgment." Jaffe, Indicial Review of Procedural Decisions and the Philco Cases: Plus Ca Change?, 50 GEo. L.J. 661, 680 (1962).

408 Office of Communication of the United Church of Christ v. FCC, 359 F.2d 994, 1007 (D.C. Cir. 1966).

409 See Joseph v. FCC, 404 F.2d 207 (D.C. Cir. 1968) ; cf. Hudson Valley Broadcasting Corp. v. FCC, 320 F.2d 723 (D.C. Cir. 1963). 
sion misconceived its mandate, ${ }^{410}$ and where issues felt by the courts to be consequential and controverted were not comprehensively considered. ${ }^{411}$

One further obstacle, deadlines for filing petitions to deny, limits the opportunity of those opposing the renewal of a license, whether competitors or those without an economic interest, to obtain a hearing. Current regulations prohibit the filing of petitions to deny renewal requests after the first day of the last full month of the expiring license term, ${ }^{412}$ giving the petitioner up to several months to respond to the licensee's renewal application. ${ }^{413}$

[T] The Commission does not condone the practice of community groups waiting until long after an application for renewal . - has been filed before raising any complaints they may have concerning a station's policies or program practices. . . . [This practice] is disruptive of the Commission's processes. ${ }^{414}$

Following this policy, the FCC, in a decision criticized by dissenting Commissioner Johnson as appearing to be the work of an "anti-citizen, anti-audience body," ${ }^{415}$ denied a time extension for filing a petition to deny sought by the St. Louis Chapter of the Congress of Racial Equality. On March 5, 1971, the Commission announced, upon granting the Colorado Committee on the Mass Media and the Spanish Surnamed, Inc., a one week extension, that " $[\mathrm{i}] \mathrm{n}$ the future . . . we shall simply deny these 'last-minute' requests, made without supporting basis." ${ }^{416}$

410 See Citizens Comm. v. FCC, 436 F.2d 263, 269 (D.C. Cir. 1970). 1970).

411 See Retail Store Employees Local 880 v. FCC, 436 F.2d 248 (D.C. Cir.

41247 C.F.R. $\$ \$ 1.580(\mathrm{i}), 1.516(\mathrm{e})(1)$ (1971).

413 See id. $\$ 1.539$ (a).

414 WSM, Inc., 24 F.C.C.2d 561, 563-64 (1970) (request for 30-day filing extension by a coalition of Nashville black community groups granted because coalition had been negotiating with the licensees; similar request by Memphis groups denied because they had not been negotiating with, and offered no reason for their delay in contacting, the licensees); of. Renewal of Licenses of Chicago Stations, 20 P \& F RADIO REG. 2D 594 (1970).

415 Congress of Racial Equality, St. Louis Chapter, 27 F.C.C.2d 353, 354 (1971). Commissioner Johnson found "no sound reason why this complaint [alleging violations of the fairness doctrine and requesting a time extension to file a petition to deny] cannot properly be prosecuted in the pending . . . renewal proceeding," citing United Church of Christ for the proposition that the FCC should "welcome the voices of opposition." Id. The FCC did, however, assure CORE that it would accord full consideration to all additional information that CORE would file to supplement its fairness complaint. Id.

410 Colorado Broadcast Stations, 28 F.C.C.2d 375, 377 (1971). Stating that "[s]ound regulation ... has procedural as well as substantive elements, and the public interest comprehends both," the Commission subsequently dismissed the group's petition to deny filed four days after the extension. WGN of Colorado, Inc., 31 F.C.C.2d 413, 413 (1971) ; cf. Time-Life Broadcast, Inc., 29 F.C.C.2d 991 (1971). See also Triangle Publications, Inc., 27 F.C.C.2d 1019 (1971). The Commission may grant extensions for petitions to intervene for good cause shown. 47 C.F.R. $\$ 1.223$ (d) 
The FCC is currently considering revising its policies on broadcast license renewals in an attempt to balance public participation and fairness to the renewal applicant. ${ }^{417}$ The proposed rules, reflecting the impact of public interest groups, were prompted by the "significant increase in the number of petitions to deny or complaints directed to license renewal applications." 418 The purpose of the new rules is to encourage a continuing dialogue between the public and the licensee throughout the license period to "ensure [that] licensees remain conversant with and attentive to community problems throughout the license period and to promote resolution of complaints as they arise at the local level through discussion between complainant and the licensee (rather than through Commission inquiry) . . . ." 419 The licensee would be required to broadcast, at least once every eight days during prime time, a short notice informing the public of the appropriate manner in which to "express their satisfaction or complaints with station operation" ${ }^{420}$ and, for a period preceding the time for renewal of its license, a notice calculated to solicit participation in the renewal process. ${ }^{421}$

Deadlines for filing renewal applications would be shifted from ninety days to four months before license expiration, and the period for filing petitions to deny would in effect be extended by one month. ${ }^{422}$ No extension of time to file petitions would be granted without the consent of all parties, including the renewal applicant. ${ }^{423}$ This consent requirement is consonant with a policy of encouraging negotiations between the licensee and those opposing renewal with a view to settling differences and obtaining promises from the licensee to alter criticized practices without requiring resort to the Commission. If a licensee were engaged in good faith negotiation, it might be expected to consent to a time extension; if instead the licensee is not negotiating or is stalling with the intent of running the complainant past the filing deadline, the complainant would have ample time in which to file. ${ }^{424}$

(1971). See Council on Radio \& Television, 23 P \& F Radro REG. 2D 185 (1971) (extension granted where licensee frustrated petitioner's attempts to examine copy of renewal application).

417 See Formulation of Rules and Policies Relating to the Renewal of Broadcast Licenses, 27 F.C.C.2d 697 (1971). See also Geller, Professor Elman's Suggestions and the Federal Communication Commission: A Comment, 59 Gro. L.J. 865, 866 (1971).

41827 F.C.C.2d at 697.

$419 I d$. at 700.

$420 \mathrm{Id}$. at 708. During the period from 6 months prior to expiration of a license to 30 days prior to expiration, a renewal notice must be announced. Id. at 709 .

421 Id. at 709-11.

422 Id. at 704. The extended filing period was in part a recognition that many community groups do not have legal counsel to prepare efficiently and file effective petitions. Id. at 706 .

423 Id. at 706-07.

$424 I d$. at 707 n.4. 


\section{The Procedural Rights and Bargaining Power of the Intervening Listener}

It thus appears that responsible public interest groups or individuals residing within the service area of a station whose license renewal is contested will be allowed to participate as parties in a renewal hearing if a petition to deny alleging adequate questions is seasonably filed. ${ }^{425}$ But an expanded definition of "interest" only increases the number of parties who may appear in a hearing. Although, by increasing the potential for large hearings, the expanded interest definition injects pressure to reduce the scope of participation of some or all participants, it neither requires such a result nor suggests how that result could be accomplished. At one point it appeared that the party status of a public interest complainant was to be inferior to that of the renewal applicant. On remand of the United Church of Christ case, for example, the FCC indicated that it was by statute ${ }^{426}$ and precedent ${ }^{427}$ permitted to place the burden of proof on the public interest group as to the issues of presentation of opposing views on important public questions and accessibility to the airways. ${ }^{428}$ The FCC felt that the intervenors were in at least as good a position as the applicant to know the facts relating to the charges of discriminatory broadcasting, and perhaps in a better position, since the applicant kept records of what it had presented, but not what it had not presented, for broadcast. ${ }^{429}$ The intervenors failed to meet this unrealistic burden, and all issues were resolved in the licensee's favor. ${ }^{430}$

In what has been described as "one of the most scathing opinions ever delivered against a federal agency," 431 the same three-judge panel that decided the first United Church of Christ appeal again reversed the FCC. ${ }^{432}$ While the decision has been thought to be procedurally "puzzling," 433 the opinion is an impassioned plea to a deaf Commission to listen:

425 Telephone interview with Henry Geller, Special Assistant to the Chairman, FCC, Aug. 26, 1971.

42647 U.S.C. $\$ 309$ (e) (1970) ("[T]he burden of proof shall be upon the applicant, except that with respect to any issue presented by a petition to deny . . . such burdens shall be as determined by the Commission.").

427 D \& E Broadcasting Co., 1 F.C.C.2d 78 (1965). The burden of proof is generally upon the party charging serious misconduct, but if no petition to deny is filed, the burden shifts to the applicant with regard to such other issues as may be delineated by the FCC. Id. at 80 .

428 Lamar Life Broadcasting Co., 3 F.C.C.2d 784, 786-87 (1966).

429 Lamar Life Ins. Co., 5 F.C.C.2d 37, 39 (1966).

430 Lamar Life Broadcasting Co., 14 F.C.C.2d 431, 433, 437-38 (1968).

431 Comment, The Aftermath of WHDH: Regulation by Competition or Protection of Mediocrity?, 118 U. PA. L. REv. 368, 377 (1970).

432 Office of Communication of the United Church of Christ v. FCC, 425 F.2d 543 (D.C. Cir. 1969).

43383 HaRv. L. REv. 1412, 1413 (1970). 
The Commission and the Examiners have an affirmative duty to assist in the development of a meaningful record which can serve as the basis for the evaluation of the licensee's performance of his duty to serve the public interest. The Public Intervenors, who were performing a public service under a mandate of this court, were entitled to a more hospitable reception in the performance of that function. As we view the record the Examiner tended to impede the exploration of the very issues which we would reasonably expect the Commission itself would have initiated; an ally was regarded as an opponent.

. . The Examiner and the Commission exhibited at best a reluctant tolerance of this court's mandate and at worst a profound hostility to the participation of the Public Intervenors and their efforts. ${ }^{434}$

Finding " $[t]$ he administrative conduct reflected in [the] record . . . beyond repair," ${ }^{435}$ the court ordered yet a new hearing, directing the FCC to invite new applications for the license, and pronounced that a public intervenor should be regarded not as a plaintiff, but "more nearly like a complaining witness who presents evidence to police or a prosecutor whose duty it is to conduct an ... investigation . . . and to pursue his prosecutorial or regulatory function if there is probable cause to believe a violation has occurred." 436

As late as 1968, Commissioners Cox and Johnson were able to comment that " $[\mathrm{g}]$ rass-roots organizations from the communities themselves rarely participate; what efforts have been attempted in this vein have not been welcomed by the Commission or its staff." 437 Participation has increased since that time, and has expanded as well into the area of informal settlements. ${ }^{438}$ The cost and time entailed by a hearing

434425 F.2d at 548-50 (footnotes omitted). The court apparently agreed with the dissent of Commissioners Cox and Johnson:

The Commission today shows its strong distaste for the presence of a complaint . . . . The record reveals that the United Church of Christ and its allies apparently have been regarded within the Commission as a kind of unfamiliar pestilence, to be scourged through harassment, the piling up of procedural obstructions, and the denial of rights clearly granted them by a reviewing court in this very same case.

Lamar Life Broadcasting Co., 14 F.C.C.2d at 464.

435425 F.2d at 550 .

436 Id. at 546.

437 Renewal of Standard Broadcast \& Television Licenses for Oklahoma, Kansas \& Nebraska, 14 F.C.C.2d 2, 9 (1968).

438 Interviews with Henry Geller, Special Assistant to the Chairman, FCC, in Philadelphia, Aug. 26, 1971, Feb. 3, 1972. Although "[i]t is impossible, or at least unlikely, that there would ever be a sufficient number of public organizations to contest each of the - . . licenses in this country," Policy Statement Concerning Comparative Hearings Involving Regular Renewal Applicants, 22 F.C.C.2d 424, 431 (1970) (Comm'r Johnson, dissenting), use of the settlement procedure may allow further increases. See text accompanying notes 441-42 infra. 
have made informal settlement of differences between the licensee and protesting community groups an attractive alternative.

The Commission possesses statutory authority to approve a settlement agreement whereby a competing applicant in a comparative hearing situation withdraws his application. ${ }^{439}$ In the recent case of $K C M C$, Inc. ${ }^{440}$ the Commission extended its power to include approval of an agreement effecting the withdrawal of a petition to deny renewal of a license. The petition, prepared by twelve local associations with the assistance of the Office of Communication of the United Church of Christ, alleged that television station KTAL, Texarkana, Texas, failed to serve the substantial black minority in its service area. The Commission assented to the withdrawal of the objections and granted renewal after a settlement between the station and the complainants, commenting that "[s]uch cooperation at the community level should prove to be more effective in improving local service than would be the imposition of strict guidelines by the Commission." 441 Commissioner Johnson, concurring in the approval of the settlement agreement "as an experimental gesture," 442 expressed concern that the agreement would herald future abdication by the Commission of its statutory duties:

A license renewal proceeding is . . . a matter between the broadcaster-licensee and all the people in the community, a matter to be resolved by the FCC according to the statutory standard of the "public interest." The Commission can utilize the services of volunteer local groups. Indeed, it is so woefully understaffed that any thorough review of broadcaster performance simply must depend upon an aroused and involved citizenry.

But just as licenses should not wrongfully be withheld, revoked or denied in response to unwarranted citizen protest, so they should not be granted automatically because a certain group of once-protesting citizens has for some reason withdrawn its objections. ${ }^{443}$

Settlement agreements may expeditiously correct operating deficiencies alleged in a petition to deny, but, because they provide no assurance that other important issues will be considered by the Commission, there inheres the risk that those issues may not be "simply resolved by finding that certain complaints have been settled." ${ }_{444}$ In $K C M C$ Commissioners Johnson and Lee were disturbed by the media concentration in

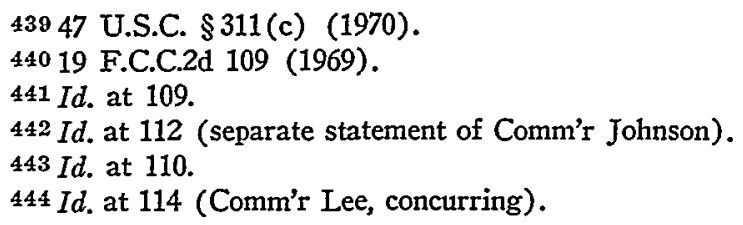


KTAL's service area, an issue which "does not disappear merely by withdrawing a complaint." ${ }^{445}$

Insofar as the desires of a single group or individual do not necessarily express, and indeed might be adverse to, the ideal of the public interest, other difficulties appear. One petitioning group might settle on terms either more or less exacting than, or different from, those another group or the Commission itself might demand. Furthermore, a potential party might hesitate to file a petition to deny in reliance on the prospect of a full hearing, only to find subsequently that a settlement has closed the door. Some control of the settlement process is clearly desirable. Representatives of the affected community and perhaps the Commission could be made indispensable or optional parties to any proposed negotiations, or settlement agreements might be publicized so as to allow opportunity for comment and modification, as is the case with provisionally accepted consent orders in the FTC. ${ }^{446}$

\section{Financing Public Advocacy}

It is said that although "the doors to greater citizen participation in the affairs of the broadcast media have been opened slightly," a "bias against citizen-initiated criticisms of the broadcasting industry has . . . remained within the structure, procedures and predispositions of the Commission." 447 The inadequacy of the investigatory staff ${ }^{448}$ and the passivity of the Commission in encouraging general citizen involvement ${ }^{449}$ make independent presentations of views by the affected public important. Various arrangements have been suggested to remedy this state of affairs. Input could be increased "by forging a connection between concerned citizen groups and the competent professional assistance required for more effective participation." ${ }^{450}$ "Former Commissioner Cox has urged that a "federation of citizens groups" establish a Washington office to inform constituent groups and act on their be-

445 Id. Nevertheless, the announced policy of the Citizens Communications Center, "a Washington public interest law firm, which has been representing citizens groups in [FCC] license renewal hearings to assure that broadcasters fulfill their public service obligations," News from the Ford Foundation, Apr. 26, 1972, at 1, is "to negotiate where possible and to withdraw from a proceeding once a licensee has agreed to improve its service." Id. 4.

446 See notes 614-15 infra \& accompanying text; cf. 47 C.F.R. $\$ 1.525$ (b) (2) (1971) (provisions for publication of notice by applicant withdrawing its conflicting application for a construction permit after a private agreement).

447 Responses, supra note 30 , at 61 (statement of Comm'r Johnson); cf. id. 64.

448 Id. 63-64, 70. In fiscal 1968 the FCC received 67,000 complaints, comments, and inquiries, but very few were ever investigated due to limited staff manpower and funds. Id. 23 (statement of Chairman Hyde), 54 (statement of Comm'r Cox).

449 Id. 63 (statement of Comm'r Johnson).

450 Id. 20 (statement of Chairman Hyde).

The Commission's position generally is to favor representation by counsel of [local groups] which participate in agency proceedings to the end that their presentations may be helpful and effective in making public interest determinations rather than disruptive of $[F C C]$ processes.

Letter from Richard E. Wiley, FCC General Counsel, to the University of Penusylvania Lare Reviere, Sept. 20, 1971. 
half. ${ }^{451}$ The Commission has debated whether to establish an "Office of Public Counsel" to advise and, in limited circumstances, represent groups. Envisioned as an entity separate from the FCC staff, it would "operate as a private law firm . . . solely as the attorney for citizens' organizations." ${ }^{452}$ Privately endowed institutions such as the United Church of Christ and the Citizens Communications Center (CCC) ${ }^{453}$ do act to fulfill this function, but both they and smaller local groups lack adequate resources to obtain professional assistance skilled in the intricacies of FCC procedure and to present able arguments for their viewpoints. ${ }^{454}$

Commissioner Johnson recognized several years ago that both the Commission's disinclination to admit representatives of the public interest and economic constraints acted to disenfranchise many groups from participation in FCC proceedings. ${ }^{45 \overline{5}}$ A similar observation may obtain in the settlement area. Several months after approval of the agreement in $K C M C^{456}$ the licensees agreed to reimburse the Office of Communication for expenses in the amount of $\$ 15,137$ incurred in assisting the local associations. ${ }^{457}$ The Commission, though finding no explicit statutory guide, adhered to the proposition "that in no petition to deny situation, whatever the nature of the petitioner, will we permit payment of expenses or other financial benefit to the petitioner." "458 Though the Commission admitted that the filing of petitions to deny should be facilitated and that settlement of issues is desirable, it nevertheless was of the opinion that payment of expenses was not necessary. The Commission, moreover, found clear detriments to the public interest in the "possibility of abuse-of overpayments . . . or

451 Responses, supra note 30, at 51 (statement of Comm'r Cox).

452 Landauer, FCC Weighs Proposals to Give Legal Aid to Public Gronps on Commission Matters, Wall St. J., June 29, 1971, at 6, col. 2 . Prospects for its establishment, however, seem dim. "We've got enough trouble in court already,' one insider contends." Id. col. 3.

453 See Citizens' Communications Center, Primer on Citizens' Access to the Federal Communications Commission (1971 Draft). Perhaps one of the most significant activities of the CCC has been to open up private policymaking meetings. See Citizens' Communications Center, Progress Report ii-viii (1971).

454 See Landauer, supra note 452 , col. 3. The Ford Foundation has, however, recently announced a grant of $\$ 400,000$ to $C C C$, intended to cover the salaries of the executive director and 3 attorneys, administration and office expenses, and litigation costs for a period of 2 years. The grant supplements those from a number of smaller foundations such as the Rockefeller Brothers Fund, the Midas International Foundation, and the Stern Family Fund. News from the Ford Foundation, Apr. 26, 1972, at 1,3 .

455 Responses, supra note 30 , at 64 (statement of Comm'r Johnson). Cf. N. Johnson, How to Talk Back to Your Television Set 74 (1970).

456 See note 440 supra \& accompanying text.

${ }^{457}$ KCMC, Inc., 25 F.C.C.2d 603 (1970), rev'd sub nom. Office of Communication of the United Church of Christ v. FCC, No. 24,672 (D.C. Cir., Mar. 28, 1972) ( $K C M C I I)$.

45825 F.C.C.2d at 605 . The FCC does, however, have broad powers to "perform any and all acts .7 as may be necessary in the execution of its functions." 47 U.S.C. \$154(i) (1970); see Reply to Opposition to Request for Reimbursement of Iegitimate \& Prudent Expenses at 6, Radio Station WSNT, Inc., 31 F.C.C.2d 1080 (1971). 
even opportunists motivated to file insubstantial petitions in order to obtain substantial fees" and in the "possibility that settlement of the merits of the dispute might be influenced by the ability to obtain reimbursement of expenses from the licensee." 459

The court of appeals, in reversing the Commission and approving the payment of such fees as the Commission would find "legitimate and prudent," took a different view of the public interest, saying:

$[T]$ he public interest standard cannot mean that the Commission may totally prohibit reimbursement in all petition to deny situations.

. . When such substantial results have been achieved, as in this case, voluntary reimbursement which obviously facilitates and encourages the participation of groups like the Church in subsequent proceedings is entirely consonant with the public interest. ${ }^{460}$

The Commission, in a case decided prior to the reversal in $K C M C$ $I I$, has also refused to compel reimbursement. In Radio Station WSNT, Inc., ${ }^{461}$ the Black Youth Club of Sandersville, Georgia, the Southern Christian Leadership Conference, and several individuals incurred expenses in prosecuting a petition to deny alleging that the licensee had discriminatory programming and hiring practices. The Commission had previously designated WSNT's application for a hearing and had made the petitioners parties to that proceeding. ${ }^{462}$ The licensee and the intervenors subsequently settled, but, unlike $K C M C I I$, there was no voluntary agreement by the licensee to reimburse expenses.

$459 \mathrm{Id}$. at 604 . Conversely, the entire renewal process has been characterized as "a burden on broadcasters and a boon for the . . . communications bar." Renewal of Standard Broadcast \& Television Licenses for Oklahoma, Kansas \& Nebraska, 14 F.C.C.2d 2, 9 (1968).

460 Office of Communication of the United Church of Christ v. FCC, No. 24,672, at 11, 18 (D.C. Cir., Mar. 28, 1972) (footnotes omitted). In responding to the FCC's fear of abuse of reimbursement, the court could not find, nor could the Commission demonstrate, any reason why a greater potential for abuse existed in a petition-to-deny situation than in the case of competing applications. $I d$. at 16 . It continued:

[T] he public interest is likewise protected from abuse by the Commission's determinations that the public group seeking to withdraw is bona fide, and that the terms of its settlement with the local broadcaster serve the public interest. Once these determinations are made, voluntary reimbursement of legitimate and prudent expenses of the withdrawing group cannot be forbidden.

Id. at 16-17 (footnotes omitted). The court considered the Commission "fully equipped" to make these determinations. Id. at 16 n.35.

The court's decision has been reported "as possibly having a far-reaching beneficial effect on the public-interest law movement and its ability to finance its lawsuits." N.Y. Times, Mar. 29, 1972, at 87, col. 3.

46131 F.C.C.2d 1080 (1971), appeal docketed sub nom. Turner v. FCC, No. 71-1800, D.C. Cir., Oct. 7, 1971.

462 Radio Station WSNT, Inc., 27 F.C.C.2d 993 (1971). 
The intervenors argued that the policy of $K C M C I I$, which was then awaiting disposition on appeal, should not be dispositive of this case, because "the act of designating a renewal application for hearing constitutes a finding that the petition to deny was meritorious and was not frivolous [and because] the question of reimbursement would be beyond the control of the intervenors or the licensee." 463 The Commission rejected the contention that a rule requiring a licensee to bear petitioners' costs when agreement is reached after designation of a hearing would provide the antagonists an incentive to settle quickly; indeed, such a rule could provide a disincentive for petitioning groups to settle prior to designation. ${ }^{464}$

In view of the usual licensee's fundamental aversion to having his renewal application designated for hearing, we are convinced that . . . lack of reimbursement [has] not deterred listener groups from filing petitions to deny or licensees from participating in discussions to resolve their differences . . . ${ }^{465}$

Since the cost of actively participating in the renewal process is almost prohibitively high, ${ }^{466}$ the $W S N T$ decision may discourage the filing of further petitions to deny and inhibit the competent negotiation of settlements, 'mak[ing] it much more difficult for citizens' groups to become active participants in the regulation of . . . broadcast licenses," ${ }^{467}$ unless the public intervenor is confident that the licensee is willing to reimburse expenses which will make possible the initiation of subsequent suits. In a renewal process which is "heavily dependent on local residents to call deficiencies to [the Commission's] attention," 468 the court's decision to permit at least a voluntary payment of reasonable costs, particularly where the FCC has found that a hearing

40331 F.C.C.2d at 1082.

$464 I d$. at 1083.

465 Id. at 1083-84. The Commission had debated only a few months earlier whether to ask Congress to appropriate funds for the payment of expenses to volunteer counsel representing public interest groups. Landauer, supra note 452 , col. 3 . It seems unlikely that the FCC, after refusing to allow individual licensees to reimburse, would itself assume that responsibility.

460 The cost of challenging renewal is extremely high. The first United Church of Christ proceeding, for example, cost the complainant funds running into six figures. Hearings on S. 2004 Before the Communications Subcomm. of the Senate Comm. on Conmerce, 91st Cong., 1st Sess., pt. 1, at 121 (1969). The New York Times estimated the cost of a proceeding to defeat license renewal at $\$ 250,000$. Id. 124. See also Fenton, siupra note 330 , at 412 . Today, $\$ 350,000-\$ 400,000$ would be a fair estimate for a full scale renewal hearing. See note 425 supra.

467 Radio Station WSNT, Inc., 23 P \& F Radio REg. 2D 53, 58b (Comm'r Johnson concurring in part \& dissenting in part); see Brief for Petitioner at 16 , Office of Communication of the United Church of Christ v. FCC, No. 24,672 (D.C. Cir., Mar. 28, 1972).

468 KCMC, Inc., 25 F.C.C.2d 603, 609 (1970) ; see. Brief for Petitioner at 13-14, Office of Communication of the United Church of Christ v. FCC, No. 24,672 (D.C. Cir., Mar. 28, 1972) ; Reply Brief for Petitioner at 16, Office of Communication of the United Church of Christ v. FCC, No. 24,672 (D.C. Cir., Mar. 28, 1972); cf. note 339 supra \& accompanying text. 
would have been required on the basis of the complainant's petition and settlement results in improved service, does not appear inequitable. ${ }^{469}$ A rule this narrow, or even the broadest possible reading of $K C M C$ $I I$ - that "when the settlement of issues and termination of a petition to deny . . . is in the public interest, voluntary reimbursement of the public group may be allowed" 470 - may, however, have limited value, and the question of voluntariness may ignore the public interest and

469 See Brief for Petitioner at 30,37, Office of Communication of the United Church of Christ v. FCC, No. 24,672 (D.C. Cir., Mar. 28, 1972) ; Reply Brief for Petitioner at 5, Office of Communication of the United Church of Christ v. FCC, No. 24,672 (D.C. Cir., Mar. 28, 1972).

That voluntariness will long remain a condition precedent to the repayment of expenses is questionable. First, it is clear that the court of appeals in KCMC II specifically rejected the FCC's "principle of general application-namely, that in no petition to deny situation, whatever the nature of the petitioner," would payment be allowed, KCMC, Inc., 25 F.C.C.2d 603, 605 (1970), by stating that "[t] he public interest. . . requires that the Commission's per se rule prohibiting reimbursement be overturned." Office of Communication of the United Church of Christ v. FCC, No. 24,672, at 17 (D.C. Cir., Mar. 28, 1972). Further, to the extent that KCMC II and the policy considerations expressed therein were the precedent governing WSNT, a precedent considered by the FCC's Broadcast Bureau as "dispositive of petitioners' request for reimbursement," Broadcast Bureau's Comment on Comments in Support of Petition for Reconsideration at 4, Radio Station WSNT, Inc., 31 F.C.C.2d 1080 (1971), KCMC II's reversal has left $W S N T$ without support in precedent. New criteria for reimbursement must now be articulated.

Concern that "it would be inappropriate . - to compel reimbursement of expenses in the absence of a voluntary agreement," WSNT, Inc., 31 F.C.C.2d at 1084, a factor regarded by the Commission as "a separate and independent ground . . . for the denial of the . . request," id., and "the foremost distinction between the two cases," $i d$. at 1083 , thus becomes the only possible line of distinction, as it indeed was for Chairman Burch, who dissented in $K C M C I I$, but who voted with the majority in WSNT. See id. at 1084 (Chairman Burch, concurring).

Several arguments have been advanced in support of involuntary reimbursement:

1. Public intervenors, as owners of the airwaves seeking to preserve their equity interest, may recover their costs where substantial benefits are realized. Comments in Support of Petition for Reconsideration at 8A, Radio Station WSNT, Inc., 31 F.C.C.2d 1080 (1971) [hereinafter cited as Petitioner's Comments].

2. Where litigation is initiated in response to the misconduct of the licensee, who is trustee of the airwaves, he must bear the expenses of that litigation. Id.; 3 A. ScotT, THE LAW OF TRUSTs $\$ 245$ (1967).

3. Fears that questions of reimbursement will influence settlements ostensibly on the merits will be assuaged if the Commission requires and regulates reimbursement, objectively evaluating the reasonableness of the claims. Motion for Remand to the Federal Communications Commission at 5, Turner v. FCC, appeal docketed, No. 71-1800, D.C. Cir., Oct. 7, 1971.

4. If reimbursement is compelled, licensees will be encouraged to negotiate in good faith so as to minimize expenses while also relieving potentially substantial burdens from the administrative machinery. Petitioner's Comments at 12-13.

5. Perhaps the most important, the statutory scheme of communications regulation requires the facilitation of citizen participation, an objective that reimbursement will surely encourage. Id. 8; see Office of Communication of the United Church of Christ v. FCC, 359 F.2d 994 (D.C. Cir. 1966).

The conclusion thus appears inevitable that, whether dictated by established trust principles to which questions of voluntariness do not apply, or by simple adherence to the mandate of protecting the "public interest, convenience, and necessity" despite malaise about the "inappropriateness" of coercing the communications industry, compulsory reimbursement will be established shortly, either by the court or the FCC itself.

470 Office of Communication of the United Church of Christ, No. 24,672, at 18 (D.C. Cir., Mar. 28, 1972) (emphasis added). 
present potentially burdensome, but not insurmountable, requirements of verification. Furthermore, private settlements without close Commission supervision do present the risk that petitioners may abuse the renewal process in order to exact concessions from licensees anxious to avoid a hearing or other impediment to renewal. Petitioning groups, for example, could make demands extraneous to the proper regulation of the broadcast industry ${ }^{471}$ or attempt to induce a licensee to pay for a promise not to file a petition to deny. ${ }^{472}$ The Commission's general reluctance to allow reimbursement to consumer intervenors unless forced by the courts neglects the rational alternative of formulating viable rules which could simultaneously encourage citizen participation and prevent possible abuses of the regulatory processes. ${ }^{43}$

\section{Conclusion}

Urged by the courts, the FCC has responded to new definitions of interest, so that virtually any local group or individual residing within a broadcaster's service area is a party in interest competent to compel a renewal hearing upon a proper showing of substantial and material questions about a licensee's past performance. Indeed, the Commission relies upon local reaction as the keystone to effective and continuous regulation. This reliance and the easy access to regulatory processes, while encouraging fuller presentation of substantive issues, does present a potential danger that some individuals or groups will negotiate inequitably with licensees eager to avoid a costly hearing where they risk the loss of a license. The settlement process promises to be an expedient and beneficial mode of regulation, but, like any private regulation, presents risks as well as advtanages. The Commission, which has yet to follow the early suggestion in United Church of Christ that rules for public participation be formulated, ${ }^{474}$ must face these problems realistically and formulate procedures to encourage the broadest public participation consistent with reasonable agency control over the determination and enforcement of the public interest.

\section{B. Civil Aeronautics Board}

Private litigants, usually airlines, cannot be expected to represent any but their own economic interests in $C A B$ proceedings. Nor does it

471 See Black Identity Educ. Ass'n, 21 P \& F Radio REg. 2D 746 (1971) (demand that licensee channel money into the black community, provide scholarships for minority group youths, and employ minority group members on board of directors).

472 See WGN of Colorado, Inc., 31 F.C.C.2d 413, 416 (1971) (demand of contribution of $\$ 15,000$ to petitioning group in consideration of promise not to press petition to deny).

473 See KCMC, Inc., 25 F.C.C.2d 603, 605-06 (1970) (dissenting opinion of Chairman Burch); id. at 611 (dissenting opinion of Comm'r Cox); Brief for Petitioner at 42-43, Office of Communication of the United Church of Christ v. FCC, No. 24,672 (D.C. Cir., Mar. 28, 1972).

474 Interview with Henry Geller, Special Assistant to the Chairman, FCC, in Philadelphia, Feb. 3, 1972. See text accompanying note 376 supra. 
seem that the Bureau of Air Operations, which "has the responsibility for developing and presenting the public's position" 475 at CAB hearings, has concerned itself with more than those same economic considerations. ${ }^{476}$ Since other considerations thus normally lack spokesmen, the provisions made in $\mathrm{CAB}$ procedures for public participation become important and it is to be expected that some changes in the CAB's heretofore restrictive intervention policy ${ }^{477}$ will be forthcoming. This section will examine the probable impact of active public participation upon the CAB's present intervention mechanisms and will suggest an accommodation between the liberalized concepts of standing and the fears that greatly increased participation could debilitate the administrative process. ${ }^{478}$

\section{Modes of Participation}

Three types of $C A B$ proceedings are most likely to attract significant numbers of public interest intervenors. These are route certification proceedings to determine whether, in the interest of the "public convenience and necessity," ${ }^{479}$ an airline should be permitted a particular freight or passenger route, rate proceedings to ascertain whether fares charged or proposed by aircarriers are "just and reasonable," 480 and proceedings to approve mergers and acquisitions of control "consistent with the public interest." ${ }^{481}$ Except in the case of ratemaking, ${ }^{482}$ hearings are generally mandatory. ${ }^{483}$

475 E. Redford, The Regulatory Process 169 (1969).

476 See generally W. Fisk, Administrative Procedure iN a Regulatory Agency: The CAB and the New York-Chicago Case (1965).

477 See, e.g., Fugazy Travel Bureau, Inc. v. CAB, 350 F.2d 733, 738 (D.C. Cir. 1965) (" $[I] t$ must be shown that the claimant will be adversely affected in a legal or property right.").

478 Writers advocating a liberalization of $\mathrm{CAB}$ intervention rules have not given due consideration to the validity of some of the objections to such liberalization. See, e.g., Boros, Intervention in Civil Aeronautics Board Proceedings, 17 AD. L. Rev. 5,37 (1965).

47949 U.S.C. \$1371(d)(1) (1970). See generally W. Jones, The LrCensing of Domestic Air Transportation by the Civid Aeronautics Board (1962).

480 See 49 U.S.C. $\$ 1374$ (a) (1970).

48149 U.S.C. $\$ 1378$ (b) (1970).

Mail-rate proceedings, see 49 U.S.C. $\$ 1376$ (1970), are generally conducted through informal negotiations and will not be dealt with in this Comment. Enforcement actions, see id. $\$ \$ 1487-89$, certainly involve the public interest, but, given their quasi-criminal nature, it may be that the Board itself represents the public interest in that type of proceeding. Cf. notes 644-57 infra \& accompanying text. Furthermore, $\mathrm{CAB}$ regulations do provide for informal participation by an "interested person" as well as the formal complainant. See 14 C.F.R. $\$ \$ 302.201,301.214$ (1971). For a discussion of the special considerations relating to third party intervention in mailrate and enforcement proceedings, see Boros, supra note 478, at 27-36.

482 See notes 489-93 infra \& accompanying text.

483 Applications for route certification "shall be set for public hearing." 49 U.S.C. $\$ 1371$ (c) (1970). Applications for approval of mergers, consolidations, and acquisitions must also be set for a hearing, except where "the Board determines that the transaction . . . does not affect the control of an air carrier directly engaged ... in air transportation, does not result in creating a monopoly, and does not tend to restrain competition, and determines that no person disclosing a substantial interest then currently is requesting a hearing . . ... Id. $\$ 1378(\mathrm{~b})$ (emphasis added). 
The provisions of the Federal Aviation Act governing public participation in $\mathrm{CAB}$ hearings do not differ radically in wording - or in vagueness-from the statutory language governing access to other federal agencies. ${ }^{484}$ The pertinent statutory provisions do not describe those persons who may actively participate in hearings. They only direct that " $[a]$ ny interested person may file . . . a protest or memorandum of opposition to or in support of" a carrier's route application ${ }^{485}$ and that "persons known to have a substantial interest" must be notified of a hearing on a merger proposal. ${ }^{486}$ Subject to the strictures of the APA, the Board has broad latitude to "conduct [its] proceedings in such manner as will be conducive to the proper dispatch of business and to the ends of justice." 487 While the absence of statutory standards has permitted the CAB to devise its own methods of accommodating or foreclosing public participation in a scheduled hearing, ${ }^{488}$ where a hearing is not mandatory, as in the case of ratemaking, the Board is not faced with merely calculating the incremental costs of additional participation but has the opportunity to avoid altogether the public scrutiny of a hearing.

\section{a. Iudicial Review and Evasion of Public Participation}

The interest of the ratepaying public in achieving meaningful participation in $\mathrm{CAB}$ fare proceedings is self-evident. Existing rates may be changed in several ways. An aircarrier may file a tariff proposal, ${ }^{489}$ which automatically will become an effective rate unless the Board, acting upon a complaint or upon its own initiative, suspends and investigates the tariff. ${ }^{490}$ The Board's decision to use or not to use its sus-

484 See Note, The Law of Administrative Standing and the Public Right of Intervention, 1967 WASH. U.L.Q. $416,433 \& \mathrm{n} .102$ (collecting regulatory statutes using the terms "party in interest," "persons aggrieved," and the like).

48549 U.S.C. $\$ 1371$ (c) (1970).

$486 I d$. $\$ 1378$ (b).

487 Id. \$1481. Cf. City of San Antonio v. CAB, 374 F.2d 326, 329 (D.C. Cir. 1967) ("Consolidation, scope of the inquiry, and similar questions are housekeeping details addressed to the discretion of the agency and, due process or statutory considerations aside, are no concern of the courts.") (footnotes omitted).

488 The failure to promulgate effective agency standards has been called the "malaise of the administrative process." City of Lawrence v. CAB, 343 F.2d 583, 587 (1st Cir. 1965).

48949 U.S.C. $\$ 1373$ (1970).

490 Id. $\$ 1482(\mathrm{~g})$. Any person may attempt to initiate a CAB proceeding by filing a complaint. "If the person complained against shall not satisfy the complaint and there shall appear to be any reasonable ground for investigating the complaint, it shall be the duty of . . the Board to investigate the matters complained of. Whenever ... the Board is of the opinion that any complaint does not state facts which warrant an investigation or action, such complaint may be dismissed without a hearing." Id. \$1482(a). The Bureau of Enforcement has a consumer complaint section that receives complaints about unsatisfactory service; the complainant does not actively participate in the investigation of alleged violations but does become a formal party to any proceedings that may be instituted. Refusals to institute formal complaint proceedings may be reviewed by the full Board. See REsponses, supra note 30 , at 7. A dismissal of a complaint without a hearing and the refusal to investigate is reviewable by courts only for an abuse of discretion. See Transconti- 
pension power is not judicially reviewable.491 The Board may itself prescribe rates by proceeding to a hearing, ${ }^{492}$ considering a set of statutory criteria, ${ }^{493}$ and formulating a final order, which may be judicially contested "by any person disclosing a substantial interest in such order." 494

The difficulty encountered by representatives of the public seeking an opportunity to participate in ratemaking proceedings may be seen in Moss v. CAB. ${ }^{495}$ In Moss several trunkline carriers filed for an increase in passenger fares after meeting informally with the Board. Having been denied access to a private conference, thirty-two congressmen complained "about the Board's continued ex parte meeting and rate practices and urged the Board to suspend the tariffs, to institute a general passenger fare investigation to define more clearly the statutory rate-making standards, and finally to set reasonable rates based on these more precise standards." ${ }^{496}$ The petitioners refused, however, to engage in an oral argument on the advisability of the use of the agency's investigatory and suspension powers "on the ground that the Board's decision on the rate increases had already been made." 497 The Board thereafter did suspend the proposed tariffs but, on its own initiative, set forth its own fare formula "and announced its decision to "permit tariff filings implementing' that formula to be filed without suspension, thus assuring almost immediate effectiveness." 498 The carriers of course adopted the proposed rate formula, and the congressmen's subsequent request that the $C A B$ suspend and investigate these new rates was, predictably, denied. ${ }^{499}$

On appeal the narrow issue was whether the Board effectively determined the rates and thus should have followed the statutory procedures of notice and hearing required for Board-made rates. ${ }^{500}$ The broader issue framed by Judge Wright of the District of Columbia Circuit was "the recurring question which has plagued public regulation of industry: whether the regulatory agency is unduly oriented toward

nental Bus Sys., Inc. v. CAB, 383 F.2d 466, 478 (5th Cir. 1967), cert. denied, 390 U.S. 920 (1968); Flight Engineers' Int'l Ass'n v. CAB, 332 F.2d 312,314 (D.C. Cir. 1964); Pan American-Grace Airways, Inc. v. CAB, 178 F.2d 34,36 (D.C. Cir. 1949). Cf. notes 404-11 supra \& accompanying text. See also Jaffe, The Individual Right to Initiate Administrative Process, 25 IowA L. Rev. 484, 512-13, 520-21 (1940).

491 See Spritzer, supra note 263, at 97-100. See also Arrow Transp. Co. v. Southern Ry., 372 U.S. 658 (1963).

49249 U.S.C. $\$ \$ 1482(\mathrm{~d}),(\mathrm{g})(1970)$.

493 Id. $\$ 1482(\mathrm{e})$.

494 Id. $\$ 1486$ (a).

495430 F.2d 891 (D.C. Cir. 1970). See Note, Some Observations on Moss v. CAB, 23 Stan. L. Rev. 833 (1971); Project, Federal Administrative Law Developments-1970, 1971 DUKE L.J. 149, 200-09.

496430 F.2d at 894.

497 Id.

498 Id. at 894-95 (footnote omitted).

499 Id. at 895 .

$500 \mathrm{Id}$. 
the industry it is designed to regulate, rather than the public interest it is designed to protect." 501 The Moss court found that "[ $t]$ he Board did all it could, short of formally styling its order as rate-making, to induce the carriers to adopt the proposed rates," ${ }^{502}$ that the exclusion of the public from the ratemaking process in these circumstances was contrary to the governing statute, and that "observance of safeguards designed to protect the public before the rates are imposed is imperative." "503 Preeminent among those safeguards is the necessity of a hearing record considering all relevant variables, so that a reviewing court can determine whether the statutory ratemaking criteria have been met. 504

The full implications of Moss have not yet been made clear, but the court "emphatically [rejected] any intimation by the Board that its responsibilities to the carriers are more important than its responsibilities to the public." 505 The court's admonition and its insistence that the Board remain faithful to the procedures of its organic statute may, however, alter little in substance if the Board is equally persistent in its industry orientation. ${ }^{506}$ The extent of agency-industry negotiation and collaboration in the formulation of rates ${ }^{507}$ and the fine, almost imperceptible line between carrier-made and agency-made fares ${ }^{508}$ make judicial intervention an uncertain curative..$^{509}$

\section{b. Participation as Parties}

Rule 15 of the CAB's rules of practice governs "formal" intervention in hearings as a full party. ${ }^{510}$ Though full party status must be accorded anyone found to have a "statutory right to be made a party," "111 there is no helpful definition of such a right and the Board,

$501 I d$, at 893. Judge Wright in large measure echoed the sentiments of a former chairman of the Board who felt "that there has been an undue shift of emphasis from public convenience and necessity to the seeking and protection of private carrier rights." Rizley, Some Personal Reflections After Eight Months as Chairman of the Civil Aeronautics Board, 22 J. ATR L. \& CoMr. 445, 450 (1955) (emphasis in original). 502430 F.2d at 898 .

503 Id. at 902 (emphasis in original).

504 See id.

$505 I d$. While the court intimated that it would be sympathetic to the use of relaxed procedures in emergencies, even those rates cannot be set without a public hearing. Id. at 901-02. The Board has "consistently refused to permit intervention in temporary rate proceedings." Northwest Airlines, Inc., Mail Rates, 12 C.A.B. 838, 839 (1951).

506 See Note, supra note 495 , at $841-45$.

507 See Spritzer, supra note 263, at 77; W. JoRdAN, AIRLINe REgulation IN AMIRRICA: EFFECTS AND IMPERfEctions 71 (1970). Cf. E. Redford, supra note 475, at $148-49,246-47$.

508 See Spritzer, supra note 263, at 82-83.

509 See 430 F.2d at 900; Project, supra note 495, at 208.

51014 C.F.R. $\$ 302.15$ (1971).

$511 I d . \S 302.15(\mathrm{a})$. 
at least prior to 1965 , never encountered a petitioner with one. ${ }^{512}$ Rule 15 further provides that "[a]ny person whose intervention will be conducive to the ends of justice and will not unduly delay the conduct of [a hearing] may be permitted to intervene." ${ }^{513}$ The rule also sets forth criteria to guide the exercise of the discretionary power to grant or deny formal intervention..$^{514}$

In terms of the number of attempted interventions, members of the regulated industry, ${ }^{515}$ affected unions, ${ }^{516}$ and civic intervenors ${ }^{517}$ cities, states, and other political subdivisions-are the most noticeable, particularly in route and merger proceedings. The criterion governing intervention has generally been whether the petitioner possesses a substantial economic interest that might be affected by a decision. ${ }^{518}$ The economic interest of an "on-line" city, one within the area of service under consideration, is so apparent that such cities formerly encountered

512 See Boros, supra note 478, at 16; cf. American-Western Merger Case, Order Granting and Denying Petitions for Leave to Intervene, No. 71-3-42, Docket 22,916 (CAB, Mar. 5, 1971) (denying formal intervention to a group of law students designating themselves as FLITE [Future Lawyers Investigating Transportation Employment] because they failed to establish a statutory right to be made a party and had no other interest).

51314 C.F.R. $\$ 302.15$ (a) (1971). The courts have approved this rule, specifically rejecting the assertion that interested persons have a right to participate as full parties in $\mathrm{CAB}$ proceedings and holding that rule 15 intervention remains within an examiner's and the Board's discretion. See Palisades Citizens Ass'n v. CAB, 420 F.2d 188, 193 (D.C. Cir. 1969) ; City of San Antonio v. CAB, 374 F.2d 326, 331 (D.C. Cir. 1967).

51414 C.F.R. $\$ 302.15(\mathrm{~b})$ (1971). The seven considerations relevant to a determination of the merits of a petition to intervene are:

(1) the nature of the petitioner's right under the statute to be made a party to the proceeding;

(2) the nature and extent of the property, financial or other interest of the petitioner;

(3) the effect of the order which may be entered in the proceeding on petitioner's interest;

(4) the availability of other means whereby the petitioner's interest may be protected;

(5) the extent to which petitioner's interest will be represented by existing parties;

(6) the extent to which petitioner's participation may reasonably be expected to assist in the development of a sound record; and

(7) the extent to which participation of the petitioner will broaden the issue or delay the proceeding.

515 See, e.g., Caribbean-Atlantic Airlines, Inc.-Eastern Air Lines, Inc., Acquisition Case, Order Granting and Denying Petitions for Leave to Intervene, No. 70-12-153, Docket 22,690 (CAB, Dec. 30, 1970).

516 See, e.g., id.; American-Trans Caribbean Merger, Intervention Order, No. 70-4-33, Docket 21,828 (CAB, Apr. 8, 1970).

517 See, e.g., City of San Antonio v. CAB, 374 F.2d 326 (D.C. Cir. 1967) ; City of Houston v. CAB, 317 F.2d 158 (D.C. Cir. 1963); Southern Transcontinental Serv. Case, 39 C.A.B. 896 (1964) ; Eastern-Colonial, Acquisition of Assets, 18 C.A.B. 453 (1954) (43 civic bodies intervened).

518 See City of Houston v. CAB, 317 F.2d 158, 160 (D.C. Cir. 1963) ; ChicagoAcapulco Nonstop Serv. Investigation, Order Granting Intervention, No. 71-3-26, Docket 22,956 (CAB, Mar. 4, 1971) ; On-Route Charter Authority of Foreign Air Carrier Permits, Intervention Order, No. 71-3-22, Docket 22,362 (CAB, Mar. 3, 1971). 
little difficulty in securing full party rights. 519 In the case of "off-line" cities and, of late, even cases involving on-line cities, however, the $C A B$ has been more restrictive, denying intervention either because civic intervenors can utilize alternative means of participation ${ }^{\mathbf{5 2 0}}$ or because their interests in the proceeding are too remote. ${ }^{521}$ Though to date no political subdivision has sought intervention on strictly noncommercial grounds, it is conceivable that, in this time of growing concern with the environment, a municipality, county, or state may attempt to put in issue the impact of a merger or route certification upon population congestion or noise pollution. The clear trend of recent federal decisions is to confer standing in such situations, ${ }^{522}$ but, in light of the CAB's heavy reliance on finding a financial or property interest as a basis for formal intervention, it is not clear that it would readily acknowledge a noneconomic interest. ${ }^{523}$

\section{c. Informal Participation}

Rule 14 of the CAB's principles of practice, ${ }^{524}$ which governs participation by non-principals in hearings, states in part that

[a]ny person, including [political units of a state], may appear at any hearing, other than in an enforcement proceeding, and present any evidence which is relevant to the issues. With the consent of the examiner or the Board . . . such person may also cross-examine witnesses directly. Such persons may also present to the examiner a written statement on the issues ....525

Persons granted intervention under rule 14 are not parties but are more properly termed "informal" intervenors. There was little difference between the rights of informal and formal intervenors until 1961, when the regulations were changed to their present form, resulting in the extinguishment of a rule 14 participant's rights after the hearing before

519 See W. Frsk, supra note 476 , at 35 (noting that 30 intervenors, mostly "on-line" cities, were granted intervention in a 1953 route proceeding).

520 See Boros, supra note 478 , at 26 (noting that petitions to intervene in the United-Capital Merger case were denied on the ground that the communities could protect their interests as "informal" participants).

521 See American-Eastern Merger, 36 C.A.B. 874, 875 (1962) (denying the city of Houston permission to intervene based upon a finding that the city "failed to disclose a property, financial, or other substantial interest in the proceeding"), rev'd per curiam, Houston v. CAB, 317 F.2d 158 (D.C. Cir. 1963) (holding Houston did have "substantial interest" since, though not served by the merging carriers, it had a competing interest with Dallas, which was so served).

522 See notes 33-120 supra \& accompanying text.

523 See note 518 supra \& accompanying text. Certainly where the civic party is geographically remote from the affected area of the proposed action, intervention may be denied.

52414 C.F.R. $\$ 302.14$ (1971).

525 Id. $\$ 302.14(\mathrm{~b})$. 
an examiner. ${ }^{526}$ Formal parties now have significant advantages, particularly in terms of their ability to appear before the Board itself. Only full parties have a right to request oral argument before either the Board or the examiner, ${ }^{527}$ to petition for discretionary review by the Board of an examiner's initial decision, ${ }^{528}$ and to file exceptions to the examiner's recommended decision or to a tentative decision by the Board. ${ }^{529}$ Whereas rule 14 intervenors must file written statements on the issues before all of the evidence is received, full parties may file briefs with the examiner or the Board after the hearing record is complete. ${ }^{530}$ Full party status, however, is not a prerequisite to judicial review, which is available to "any person disclosing a substantial interest" in the subject matter of an order. ${ }^{531}$ That the extent of participation by an intervenor under rule 14 is confined to the initial hearing and largely turns upon the will of the examiner is of unquestionable significance. ${ }^{532}$ Relegation to rule 14 status might deprive a public intervenor of the important ability to fully pursue its interest through both the hearing and appeal process to the Board.

In Palisades Citizens Association v. $C A B,{ }^{533}$ several associations of citizens, styling themselves "Concerned Citizens," sought formal or, alternatively, informal intervention in a certification hearing on a proposed helicopter route in the Baltimore-Washington area. The Citizens alleged in substance that their participation would help insure that the record would reflect the environmental impact of the proposed service. The petitioners did not seek to introduce their own evidence on the adverse environmental consequences of certification but, rather, demanded that the carrier applicants be compelled to make studies and adduce such evidence. ${ }^{534}$ Considering the criteria provided by rule

526 See Boros, supra note 478, at 16.

527 See 14 C.F.R. $\$ \$ 302.25,302.32$ (1971).

528 See id. $\$ 302.28$.

529 See id. $\$ 302.30$.

530 See id. $\$ \$ 302.26,302.31$.

531 Compare 16 U.S.C. $\$ 8551$ (b) (1970) (Federal Power Act) and 15 U.S.C. $\$ 717 \mathrm{r}$ (b) (1970) (Natural Gas Act) with 49 U.S.C. \$1486(a) (1970) (Federal Aviation Act). See Brief for Respondent at 24, Palisades Citizens Ass'n v. CAB, 420 F.2d 188 (D.C. Cir. 1969) [hereinafter cited as Brief]; Shapiro, supra note 37, at 767. On the other hand, the grant of formal intervention is "for administrative purposes only, and no decision granting leave to intervene shall be deemed to constitute an expression by the Board that the intervening party has such a substantial interest in the order that is to be entered in the proceeding as will entitle it to judicial review of such order." 14 C.F.R. $\$ 302.15$ (d).

532 See Comment, Adequacy of Domestic Airline Service: The Community's Role in a Changing Industry, 68 YALE L.J. 1199, $1218 \mathrm{n} .93$ (1959) (quoting address by Perry H. Taft, National Airport Conf., Nov. 3, 1957, indicating that a community, to be successful before the $\mathrm{CAB}$, must participate in all stages of the proceedings). The advantages inherent in the opportunity to argue orally before the Board, as opposed to simply participating before the examiner, are suggested by the description or oral arguments in the Nere York-Chicago case. See W. FIsk, supra note 476, at 75 .

533420 F.2d 188 (D.C. Cir. 1969).

534 Id. at 190 . 
$15{ }^{535}$ the Board affirmed the examiner's denial of formal intervention in favor of rule 14 participation. The Board found that, though "interested persons" have a right to file written position statements, ${ }^{536}$ the petitioners had no statutory right to actively participate in the proceedings, ${ }^{537}$ that the petitioners' interest was not uniquely identifiable apart from the general public's, ${ }^{538}$ that the Department of Transportation, which was allowed party status, would be the principal public spokesman for representing the petitioners' concerns, ${ }^{539}$ that the petitioners would not themselves affirmatively offer any evidence concerning environmental impact, ${ }^{540}$ and that if the Citizens were allowed to participate as parties the proceedings would be "nearly uncontrollable." 541 The Board concluded that informal rule 14 participation "strikes the practical balance between the general public's interest in viable administrative proceedings and the private interests of individual members of the general public." 542

The court on appeal recognized the relevance of environmental concerns and acknowledged the Citizens' "keen interest" in the proceedings, but sustained the Board's denial of formal intervention. ${ }^{543}$ The Palisades court's reasons for upholding the denial of intervention brings into relief perhaps the major difficulty that will confront public interest groups attempting to intervene as parties in Board hearings. The Citizens were not denied all opportunity to participate in the route proceeding; rather, they were granted quite generous privileges as informal intervenors. In this capacity they were allowed to present exhibits, to file a written statement of their position, to cross-examine extensively, and to argue orally before the examiner. ${ }^{544}$ In light of these privileges, the court felt that the Citizens' role "amounted to a reduction of [their] status in form only, rather than in substance." 545 The salient question raised by this decision is whether the informal status afforded the Citizens, readily accepted by the court as a representative environmentalist group, ${ }^{546}$ adequately protects the public's interest in the environment. ${ }^{547}$

535 See note 514 supra.

536 See note 485 supra \& accompanying text.

537 See Brief, supra note 531, at 26-27; cf. City of San Antonio v. CAB, 374

F.2d 326, 331 (D.C. Cir. 1967).

538 Brief, supre note 531, at 27-28.

539 Id. 30-31. Cf. American-Trans Caribbean Merger, Intervention Order, No.

70-4-33, Docket 21,828 (CAB, Apr. 8, 1970).

540 Brief, supra note 531, at 31 .

541 Id. $33 ; 420 \mathrm{~F} .2 \mathrm{~d}$ at 191 .

542 Brief, subpra note 531, at 33; 420 F.2d at 191.

$543420 \mathrm{~F} .2 \mathrm{~d}$ at 193.

544 Id. See Brief, supra note 531, at 11.

545420 F.2d at 193.

546 Although the Concerned Citizens were private property owners, the court largely ignored that fact, choosing to look upon the group as a potential representative of the public interest in the environment. See id. at 190.

547 See Brief, supra note 531, at 35-38 (statement of the Department of Justice to the effect that the petitioners should have a legal right to intervene as parties). 
To the extent that Palisades sanctions a general Board policy of denying rule 15 rights to public intervenors, ${ }^{548}$ thereby foreclosing direct access to the Board, it effectively accommodates some of the concerns which led to the 1961 rule change. ${ }^{549}$ One of the objections to full participation by third party groups centered upon the tendency of often inept civic intervenors to encumber the hearing and review procedures with poorly prepared presentations. ${ }^{550}$ Another frequently encountered objection has been that full intervention by such parties tends to protract and enlarge hearings to unmanageable proportions. ${ }^{551}$ The likelihood of such time consumption is substantiated by the fact that ninety-five percent of $\mathrm{CAB}$ hearing time is consumed by crossexamination and re-cross-examination, ${ }^{552}$ and an increase in the number of full parties possessing the right to cross-examine might well lead to a geometric increase in expended hearing time.

The considerations against allowing public interest groups full rule 15 intervention are not to be taken lightly. Numerous civic parties or

548 The Board policy on allowing intervention has been restrictive. "Perhaps, this [1961] rule change would not have been so unfortunate had the Board adopted a more liberal approach to permitting intervention under Rule 15 . It has not done so. Intervention has been more sparingly granted than formerly." Boros, supra note 478, at 17 (footnote omitted). The Board itself, however, has said that its "regulations and its generally liberal approach in their administration have encouraged citizen-group input." RESPONSES, supra note 30, at 5-6.

549 One of the chief reasons for the 1961 rule change, not applicable to the broad question of public interest group intervention, was $C A B$ concern over frequent appearances at Board hearings by congressmen, senators, and state officials seeking to place overt political pressure upon the decisionmaking process. See Boros, supra note 478, at 16-17. See also Rizley, supra note 501, at 450.

550 See Boros, supra note 478, at 21. But cf. W. FrsK, supra note 476 , at 41 (recounting the preparation of a "fairly typical civic intervenor" in the $1953 \mathrm{New}$ York-Chicago route certification case).

551 See, e.g., Senate Subcomim. on Admin. Practice \& Procedure, 89Th Cong., 2D Sess., Questionnatre Survey on Deiay in Administrative Proceedings 32 (Comm. Print 1966) [hereinafter cited as QuestronnaIRe]; City of San Antonio v. CAB, 374 F.2d 326, 332 (D.C. Cir. 1967) (" $[T]$ he Board found that there were already at least 65 parties to the proceeding, and to allow petitioners and cities similarly situated to intervene would in effect defeat the very purpose of the consolidation order which, of course, was to keep the proceeding within manageable limits."). In Riddle Airlines, Inc., 28 C.A.B. 15 (1958), the Board allowed the L.B. Smith Aircraft Corp. oral argument to protest the granting of a subsidy to a competitor, but denied a petition to intervene, stating that "[i]t does not appear that Smith's participation may reasonably be expected to assist in the development of a sound record, nor does it appear that Smith has an interest which could not adequately be served by participation in the proceeding pursuant to rule 14 of the Board's rules of practice. Moreover, Smith's participation as an intervenor would broaden the issues herein and delay the proceeding." Id. at 21 . The view that a liberal intervention policy will unnecessarily delay proceedings has been called "one of the most oft-repeated myths" in the CAB. Boros, supra note 478 , at 21 . The Board itself feels that its "decision-making procedures operate with reasonable speed considering the breadth and complexity of the issues involved." RESPONSES, supra note 30 , at 11.

552 Pfeiffer, Shortening the Record in CAB Proceedings Through Elimination of Umecessary and Hazardons Cross-Examination, 22 J. AIR L. \& Cons. 286, 287 (1955). $C f$. W. JoNEs, supra note 479 , at 122 ("Everyone seems to agree that crossexamination often is excessive ....). The procedural rules require that direct evidence be presented in written form whenever feasible. See 14 C.F.R. $\$ 302.24$ (b) (1971). This is in harmony with the APA, which compels only "such cross-examination as may be required for a full and fair disclosure of the facts." 5 U.S.C. $\$ 556(\mathrm{~d})$ (1970). 
more than one environmentalist group can be expected to adduce repetitive and often immaterial evidence. A right of cross-examination is also subject to abuse, and the more parties possessing the right, the more potential for dilatory abuse exists. Furthermore, the necessity of wading through the additional briefs and a copious hearing record, which would result from the granting of full intervention to third parties, would add to the delay plaguing CAB proceedings. ${ }^{553}$ It certainly must be conceded that to have fewer parties in any particular proceeding will, to some degree, expedite the disposition of the matter at hand, ${ }^{554}$ but expediency in itself should not be a legitimate ground for foreclosing participation. ${ }^{555}$

In addition to these considerations, the evidence an environmentalist group can be expected to introduce at a hearing will often fall within the ambit of what Professor Davis calls "legislative fact" or "general facts which help the tribunal decide questions of law and policy and discretion." 556 In Palisades, for example, the Concerned Citizens argued that investigation would prove "that helicopters pollute the air far more per passenger mile than automotive vehicles." 557 The advisability of allowing cross-examination of evidence bearing on such issues has been seriously questioned. ${ }^{558}$ Such policy matters involving legislative fact may be better decided through the rulemaking than the adjudicatory process. ${ }^{559}$ Even in those situations where the environmental considerations introduced are clearly adjudicatory in nature, the vast majority of such facts would seem to lend themselves well to presentation by exhibits, statistics, and written statements. It is, therefore, at least questionable whether cross-examination and other procedures attendant to full party status need be universally available.

553 See Boros, supra note 478 , at 22 (indicating that in excess of 1 year generally expires between the examiner's initial decision and the Board's decision in certification cases).

554 It is impossible to say with certainty just how much effort the Board typically expends in going through the hearing record, as very little is known about the internal workings of the Board itself. See W. FISK, supra note 476 , at 76 (referring to the deliberations of the Board as "the most important, the most interesting, and the most obscure" aspect of a CAB proceeding) ; cf. RESPONSES, supra note 30, at 10 .

555 See Boros, supra note 478, at 22; Virginia Petroleum Jobbers Ass'n v. FPC, 265 F.2d 364, 367-68 n.1 (D.C. Cir. 1959).

$5561 \mathrm{~K}$. DAvis, supra note 23 , \$7.02, at 413.

${ }^{557}$ See Harkaway, Air Pollution-The Federal Power Commission and Other Federal Agencies, 3 Nat. Res. LAw. 66, 71 (1970). The Board rejected the contention, but there will undoubtedly "be considerably more air pollution evidence offered into its proceedings in the future." Id. 72.

558 See Pfeiffer, supra note 552, at 296-97; W. JoNEs, supra note 479, at 122.

559 But cf. Robinson, supra note 191, at 521. See also Clagett, supra note 198, at 77-80 (suggesting flexible procedural devices).

The problem of policy-oriented cross-examination will not normally arise in the rulemaking context, inasmuch as the Administrative Procedure Act's rulemaking provisions do not require the holding of a full evidentiary hearing. See 5 U.S.C. $\$ \$ 553(\mathrm{c}), 556(\mathrm{~d})$ (1970). Where the Board's order has "'future effect'.. - of both general and particular applicability," only the opportunity to submit written data and argument by the interested parties is required. Law Motor Freight, Inc. v. CAB, 364 F.2d 139, 143 (1st Cir. 1966), cert. denied, 387 U.S. 905 (1967). 
Notwithstanding the foregoing conclusion, it is possible that, in particular circumstances, participation limited by the strictures of rule 14 will not adequately air the public interest before the Board. In Palisades the Board did weigh the question of environmental impact against the need for helicopter service, finding the latter consideration persuasive $^{560}$ The Board's final decision undertook a discussion of each point raised by the Citizens, disposing of each in a reasonable fashion. $^{561}$ The Palisades court seemed to think that the Department of Transportation, as a formal intervenor, actively represented environmental concerns throughout the certification proceeding. ${ }^{562}$ There is no assurance, however, that future Boards will treat public interest groups as fairly or that there will be existing adequate representation as a matter of course, ${ }^{563}$ especially as economic considerations dominate Board and examiner hearings. In light of governmental opposition to environmentalist groups in other agency proceedings ${ }^{564}$ the most vigorous, effective, and faithful representation of the environmentalist position can hardly be expected over a range of cases. The notion that the agency charged with conducting a hearing adequately protects the public interest has been rejected. ${ }^{565}$ Relegation to rule 14 status without a discretionary broadening of the party's rights may not provide for a fair and full appraisal of significant aspects of the public interest. Rationalization about surrogate representation and concern with unduly extended proceedings cannot obscure the possibility that rule 14 could be employed to circumvent the broad purpose of Moss by effectively excluding the public from the $\mathrm{CAB}$ decisional process. ${ }^{586}$

\section{A Proposal}

Against the backdrop of these competing considerations-the desirability of expeditious procedure and the need for full consideration

560420 F.2d at 193. See also Glass, Planning for Suburban Heliports, 22 J. AIR L. \& CoM. 271, 281 (1955) (including among the factors to be considered in selecting heliport sites the "[p]ossible effect on use of neighboring property as a result of noise of helicopter operations and air blast effects.").

561420 F.2d at 193 n.7.

562 See id. at 193. The Department of Transportation had, however, no "scientifically acceptable basis for estimating the extent of helicopter air pollution." Harkaway, supra note 557, at 71-72.

563 The Board has not appointed any citizen advisory groups, but trade and industry groups do advise the Board on their special fields of interest. "The information derived through exchanges with such groups provides the Board with an informed basis for carrying out policy-making and decision-making functions." Furthermore, the Board does not "seek out the views of persons who would not otherwise be likely to present their views to the Board." Responses, supra note 30 , at 6 . The Board does claim, however, "that those persons that are affected by the Board's activities know enough about them" by means of notice and distribution of information. Id. 8 .

564 See, e.g., Sierra Club v. Hickel, 433 F.2d 24 (9th Cir. 1970), aff'd sub nom. Sierra Club v. Morton, 40 U.S.L.W. 4397 (U.S. Apr. 19, 1972) (action for declaratory judgment and injunction against Secretaries of Interior and Agriculture brought by environmentalist group).

565 See, e.g. Office of Communication of the United Church of Christ v. FCC,

359 F.2d 994, 1003-04 (D.C. Cir. 1966).

566 See notes 495-509 supra \& accompanying text. 
of the public interest-Palisades suggests an intervention scheme that may effectively accommodate the broad spectrum of interests affected by $\mathrm{CAB}$ activity. The court in that case did not approve the simple consignment of the Citizens to a status strictly limited by the language of rule 14, for the petitioners enjoyed more rights than rule 14 minimally confers. ${ }^{567}$ In addition to the presentation of exhibits and a written statement of the issues, the Citizens were granted the discretionary privileges of cross-examination and oral argument before the examiner. ${ }^{568}$ In light of those privileges, the court's statement that the Citizens' position under rule 14 was "a reduction of . . . status in form only" ${ }^{569}$ is more convincing. When compared, for example, with restrictive limitation on participation allowed nonparties in AEC proceedings, ${ }^{\mathbf{5 7 0}}$ it is apparent that rule $\mathbf{1 4}$, as employed in Palisades, does not preclude a reasonable solution to the problem of public interest intervention.

If rule 14 status was indeed a handicap in form only, the question remains whether there was any reason not to grant the Citizens rule 15 status. The obvious answer is that there was. Even if the court's assertion that "that which might have been accomplished under Rule 15 was, in fact, effected through Rule 14" 571 cannot be taken as wholly true, the court did lend its imprimatur to the flexibility shown by the examiner and the Board in that particular case in conferring upon the Citizens privileges not even mentioned in rule $14 .^{572}$ The court unfor-

507 See text accompanying notes $544-45$ supra.

508 See 420 F.2d at 193.

569 Id.

570 See text accompanying notes $851-52$ infra.

571420 F.2d at 193.

572 The Board recently denied a petition to intervene as a party filed by the Aviation Consumer Action Project (ACAP) but, in addition to permitting rule 14 participation, "determined to permit ACAP to file a post-hearing brief or statement of position with the examiner and in the event of further proceedings to file a brief or statement of position with the Board and to participate in any oral argument which may be ordered." American-Western Merger Case, Order at 1, No. 71-11-43, Docket 22,916 (CAB, Nov. 11, 1971). The Board thought that its unusual action would not unduly burden the proceedings and "could, moreover, prove helpful in this case since ... ACAP is the only participant of its type in the proceeding. [The Board emphasized], however, that this limited permission (which does not constitute formal intervention) is being granted solely as a matter of grace, and is not to be taken as a precedent, either under Rule 15 or otherwise." Id. at 3. The Board warned that "neither the Federal Aviation Act nor the courts have placed on the Board the requirement of permitting formal intervention . . to groups which have no direct and substantial economic interest in the proceeding at hand and which may in reality turn out to consist of no more than one or a few individuals." Id. at 3 n.6. Commenting upon ACAP's failure to show that it would be a responsible spokesman for "a broadly based organization representing a significant segment of the public", the Board said that it would "expect future petitions to intervene from this and other such groups to provide more detailed information to permit us to ascertain whether formal intervention, as opposed to Rule 14 participation, is appropriate." Id.

ACAP had filed an untimely petition, but claimed that it was entitled as a "public body" to a more lenient filing deadline. See 14 C.F.R. $\$ 302.15$ (c) (2) (iii) (1971). The Board rejected this contention, stating that the filing exception was intended to benefit local government bodies which "frequently find it difficult to meet the generally applicable deadline because of lack of familiarity with federal agency procedure, lack 
tunately evinced no apprehension that this flexibility might not be so wisely utilized in future cases. Unlike rule 15 , whose seven criteria ${ }^{573}$ at least provide a skeletal guide to the exercise of the examiner's discretion in weighing a petition for formal intervention, rule 14 does not indicate what factors should determine the scope of the privileges, if any, to be accorded a rule 14 intervenor. The court's opinion in Palisades concludes with the hedging assertion that "[i]t is for the Board to determine who will best serve to amplify the facts pertinent to [the public] interest ...."574 Given the absence of standards to guide that determination, there is no assurance that the relatively equitable solution reached in Palisades often will be repeated.

The APA provides that the reasons underlying an agency's findings or conclusions shall be shown on the record, ${ }^{575}$ and any failure to do so may constitute reversible error. ${ }^{576}$ At a minimum, rule 14 should contain a set of criteria similar in purpose to those found in rule 15. The grant or denial of an informal intervenor's privileges could be weighed against these standards, and the scope of any grant could be tailored to the needs of the intervenor in each particular case. To facilitate review of contested denials of privilege and to insure that each intervenor is dealt with as flexibly as were the Citizens, the reasons underlying the examiner's or Board's action should be articulated. As presently drafted, rule 14 invites a stream of Palisades-like appeals attacking Board action as arbitrary or as lacking articulated reasons. Intelligible standards controlling the evidentiary and appellate ${ }^{\mathbf{5 7 7}}$ privileges granted the rule 14 intervenor can insure fairness with some regularity.

To achieve this result, rule 14 could be restructured by adding a subsection (c) providing that:

1) After determining that the facts do not warrant a person's formal intervention as a full party under rule 15 but that limited participation under this rule is warranted, the examiner (or the Board) may, in the exercise of discretion, allow the person so participating under this rule one or more of the following privileges:

of information about prehearing conferences in proceedings in which they might have an interest, the frequent need to locate and employ special legal counsel for the purpose, and other similar factors." Order at 2. The Board found that ACAP was a national organization with knowledgeable counsel, but intimated that other local nongovernmental groups might be eligible for the relaxed filing requirements in the future. Id. at $2 \&$ n.3.

573 See note 514 supra.

574420 F.2d at 193. Cf. City of San Antonio v. CAB, 374 F.2d 326, 329 (D.C.

Cir. 1967) ; Frontier Airlines, Inc. v. CAB, 349 F.2d 587, 591 (10th Cir. 1965).

5755 U.S.C. $\$ 557$ (c) (1970).

576 See, e.g., City of Lawrence v. CAB, 343 F.2d 583, 588 (1st Cir. 1965); Northeast Airlines, Inc. v. CAB, 331 F.2d 579 (1st Cir. 1964).

577 "Appellate" here refers to those stages of a Board proceeding occurring after an examiner's initial decision. 
i) the opportunity to cross-examine witnesses;

ii) the opportunity to argue orally before the examiner and/or the Board;

iii) the opportunity to file exceptions to one or more findings of fact or conclusions of the examiner or the Board; and

iv) the opportunity to present to the examiner and/or to the Board a brief prepared after the termination of the examiner's hearings.

2) In passing upon petitions by persons seeking these privileges, the following factors, among others, will be considered:

i) the necessity of balancing the considerations to be advanced by the person participating under this rule with those advanced by other participants;

ii) the possibility that the Board may not be as familiar with the hearing record as with the factual and policy considerations presented directly by means of brief and/or oral argument;

iii) the presumption in favor of non-duplicative testimony, argument, and cross-examination, provided that relevancy to the issues at hand has been established; and

iv) the extent to which formal parties to the proceedings can reasonably be expected to represent adequately the interests of the rule 14 participant at each and every stage of the proceeding.

Given the CAB's widespread use of the prehearing conference, ${ }^{578}$ the examiner has the opportunity, by fixing the "ground rules" of the impending hearing, to make a fair and thorough determination of which privileges to grant. Certainly much can be done at the conference to ascertain what evidence will be cumulative or irrelevant, where the examiner might benefit from cross-examination by the various parties, and which issues might be fully presented only by brief and oral argument. ${ }^{579}$ Since the fear of reversal often prevents an examiner from making an exclusionary ruling in the midst of a hearing, ${ }^{580}$ the compulsion to list reasons for a prehearing or midhearing ruling would seem to substantially lessen the possibility of Board or judicial reversal.

578 See 14 C.F.R. $\$ 302.23$ (1971); QUESTIONNAIRE, supra note 551, at $28,31$. See also W. Jones, supra note 479 , at $45,140-41$.

$\mathbf{5 7 9}$ See Westwood, Administrative Proceedings: Techniques of Presiding, 50 A.B.A.J. 659 (1964).

580 See Prestdent's Conference on Administrative Procedure, Report of the Conference on Adninistrative Procedure 53-54 (1955). 
Rather than allowing a hobbling influx of public interest litigants at every stage of every proceeding, a case-by-case method of giving the public a forum while preserving the independence and flexibility of the administrative process may thus be developed.

Increased public participation before the $C A B$ and other federal agencies demands recognition of an agency's "basic right to limit the scope of its inquiries" ${ }^{581}$ through the judicious employment of efficient procedure. As "[a]dequate protection for interests obliquely affected may often be afforded through limited participation," 582 the embryo of a reasonable, flexible intervention scheme may be found in the present $\mathrm{CAB}$ rules. With the modification suggested above, those rules, when generously applied, are capable of accommodating all interests and may well prove the prototype of fair public participation for all federal regulatory agencies.

\section{Federal Trade Commission}

Perhaps the most difficult conceptual and practical problems with public interest intervention arise in the context of the Federal Trade Commission. While the other agencies considered serve the primary function of allocating resources and privileges, the primary role of the FTC, as it is presently constituted ${ }^{583}$ is to prosecute parties who violate federal statutes, ${ }^{584}$ particularly those who engage in unfair trade prac-

581 Frontier Airlines, Inc. v. CAB, 349 F.2d 587, 591 (10th Cir. 1965). $752-56$.

5823 K. DAvis, supra note $23, \S 22.08$, at 241 . See Shapiro, supra note 37 , at

583 Former FTC Commissioner Elman has recently suggested that "Congress should transfer the FTC's adjudicative function either to the district courts or, preferably, to a new Trade Court, which would be decentralized and hold hearings in every state, thus bringing the judicial phase of the regulatory process much closer to the people. The Trade Court could be given jurisdiction not only of complaints prosecuted by the agency, but also private class action suits brought by consumers and competitors injured by the same alleged unfair trade practices." The FTC's remaining functions would be "vested in a single commissioner serving at the pleasure of both the President and Congress and removable by either," in order to increase the FTC's accountability and therefore its responsiveness to the public and to enable it to pursue "a single central objective: the development and enforcement of regulatory policies carrying out the statutory mandate" through special investigations and expanded use of trade regulation rules and similar policy statements. Elman, $A$ Modest Proposal for Radical Reform, 56 A.B.A.J. 1045, 1048-49 (1970); cf. ABA Commission to Study the Federal Trade Commission, Report 90 (1969) [hereinafter cited as ABA REPORT] (concurring statement of John D. French suggesting the transfer of prosecutorial functions to the Department of Justice, leaving the FTC to function as "a trade regulation court, commentator, and rulemaker"); PRESIDENT's Advisory Council on Executive Organization, A New Regulatory Franework: Report on Selected Independent Regulatory Agencies 87 (1971) (the "Ash Council Report," recommending abolition of the FTC and transfer of its antitrust and consumer protection functions to separate new agencies); REPORT OF ABA SECtron of Antitrust Law to Study the Ash Council Report (1971) (rejecting the report and recommending instead the transfer of adjudicative functions to a new administrative court).

584 For a survey of the FTC's statutory authority and responsibilities, see ABA RePORT, supra note 583 , at 6-7. 
tices ${ }^{585}$ or conspire to lessen competition. ${ }^{586}$ The Commission employs a range of enforcement techniques varying with the seriousness of the offense, the need for prompt compliance with the law, the probability of winning the case if the Commission were put to its proof in a formal adjudicatory proceeding, and competing demands placed upon its resources. The Commission may seek an assurance of voluntary compliance or of informal corrective action, or it may negotiate a consent order with a party suspected of violating the law. If such negotiations fail, or if the Commission feels the issues cannot be satisfactorily resolved through such negotiation, it may initiate formal adjudicative proceedings against such a party.

\section{Informal Proceedings}

Informal proceedings, which dispose of the bulk of the Commission's cases, ${ }^{587}$ can commence in several ways. The Commission may negotiate directly with the party suspected of violating the law to effect an informal corrective action, which may consist of nothing more than an oral promise or exchange of letters, or it may secure an assurance of voluntary compliance. ${ }^{58}$ In such cases the proceeding never goes beyond the stage of informal discussions. In informal corrective actions, the assurances of voluntary compliance are not reported by the Commission; they remain confidential, putatively to protect the reputation of the complying party. The legal effect of such assurance is unclear for, unlike a consent order, ${ }^{589}$ it does not contain an admission of jurisdictional facts and waivers of procedural steps, of the requirement that the Commission state its findings of fact and conclusions of law, and of rights of judicial review and other challenges to its validity. Presumably, if the assurance is violated, the Commission's recourse is to seek a consent order or to institute a formal proceeding.

Under the consent order procedure, the Commission may notify a party of "its intention to institute a formal proceeding" ${ }^{500}$ against that party. The proposed respondent may then "file . . . a reply stating whether or not he is interested in having the proceeding disposed of by

585 See 15 U.S.C. \$ 45 (1970).

586 The FTC and the Department of Justice have concurrent jurisdiction to enforce $\$ \S 2,3,7 \& 8$ of the Clayton Act, 15 U.S.C. $\$ \$ 13,14,18-19$ (1970). See 15 U.S.C. $\$ 21$ (1970).

587 Approximately $90 \%$ of FTC cases are disposed of by consent orders. Telephone interview with Joachim Volhard, Office of FTC Commissioner MacIntyre, Aug. 1971. This estimate does not take into account assurances of voluntary compliance or informal corrective actions. Cf. ABA REPORT, supra note 583, at 16-26. The $A B A$ Report detected a trend toward greater reliance on informal proceedings, and concluded that "the de-emphasis of formal enforcement has gone too far." Id. 25. Undoubtedly, however, "the Commission would not be able to function without a system of consent settlement." Auerbach, The Federal Trade Commission: Internal Organization and Procedutre, 48 MrNN. L. Rev. 383, 424 (1964).

588 See 16 C.F.R. $\$ 2.21$ (1971). For a statistical analysis of recent assurances, see ABA REPORT, sipra note 583, at $22-23$.

58916 C.F.R. $\$ 2.33$ (1971).

590 Id. $\$ 2.31$. 
the entry of a consent order." 591 The proceeding is not adversary; it is a bargaining session conducted in confidence by parties both of whom have an interest in avoiding formal adjudication. ${ }^{52}$ The proposed respondent does not admit to a violation of law (thus preventing private suitors from using the order as evidence in a damage suit) but merely agrees to comply with Commission requirements. As the Supreme Court has recently noted of consent orders obtained by the Department of Justice:

Consent decrees are entered into by parties to a case after careful negotiation has produced agreement on their precise terms. The parties waive their right to litigate the issues involved in the case and thus save themselves the time, expense, and inevitable risk of litigation. Naturally the agreement reached normally embodies a compromise; in exchange for the saving of cost and elimination of risk, the parties each give up something they might have won had they proceeded with the litigation. . .

[T] he scope of a consent decree must be discerned within its four corners, and not by reference to what might satisfy the purposes of one of the parties to it. ${ }^{593}$

What of those who are not party to a consent order but whose interests are affected by it? If agreement is reached, the Commission will provisionally accept it and

will place the order contained therein on the public record for a period of thirty (30) days, during which it will receive and consider any comments or views concerning the order that may be filed by any interested persons. Within ten (10) days thereafter, the Commission may either withdraw its acceptance of the agreement and so notify the other party, in which event it will take such other action as it may consider appropriate, or issue and serve its complaint (in such form as the circumstances require), and decision, in disposition of the proceeding. ${ }^{594}$

591 Id. $\S 2.32$.

592 One former official of the Department of Justice has expressed concern that the Government's interests in avoiding litigation-the efficient allocation of enforcement resources and the immediate procurement of relief as contrasted with obtaining compliance only after protracted litigation-might be jeopardized by allowing intervention as of right by private parties in consent decree proceedings. "Where the Government has concluded that the added amount of relief which might theoretically be obtained would involve protracted litigation and use of enforcement resources which could be put to better use elswhere, the private intervenor would rarely if ever be in a position to second-guess that judgment." Letter from Donald F. Turner to Representative Emanuel Celler, Mar. 17, 1967, in BNA ANTITRUST \& TRAdE REg. Rep., Mar. 21, 1967, at X-1, X-2 to -3 .

593 United States v. Armour \& Co., 402 U.S. 673, 681-82 (1971).

59416 C.F.R. $\$ 2.34$ (b) (1971). This provision for public comment took effect on July 1, 1967, 4 years after the Department of Justice had adopted a similar policy. 
Comments may be received from a variety of sources. Because the proposed orders are published in the Federal Register, however, only well-organized interests are likely to be fully informed of their significance and have the resources to present cogent commentary in the limited time available. ${ }^{595}$ Other concerned parties must generally rely on the limited coverage given FTC activities by the press, which alternative the Commission has made little effort to improve. ${ }^{596}$ There is, of course, no assurance that any comments received will have any effect; in fact, there have been very few cases in which a proposed consent order has been withdrawn or modified because of public comment. ${ }^{597}$ This is in no way surprising. By the time the Commission issues a provisional consent order, it has, for all practical purposes, made up its mind.

That current informal enforcement procedures insufficiently allow significant participation by third parties is being urged by a group of George Washington University law students incorporated as Students Opposing Unfair Practices, Inc. (SOUP), in their appeal of the Commission's acceptance of a consent agreement with the Campbell Soup Company. ${ }^{598}$ Campbell had been charged with placing marbles in a

The FTC had previously opposed such disclosure. See Auerbach, supra note 587, at 445-49. Cf. 16 C.F.R. $\$ 1.4$ (1971) (public comment on limited class of FTC advisory opinions).

595 See notes $253-55$ supra \& accompanying text.

596 See Responses, supra note 30, at 195 (statement of FTC Comm'r Mary Gardiner Jones); cf. id. 116 (statement of former Comm'r Paul R. Dixon).

597 See Chrysler Corp., 4 CCH Consumer Credit Gume $\$ 99,596$ (FTC 1971); Hemphill Enterprises, Inc., [1967-1970 Transfer Binder] TRADE REG. REP. $\mathbb{1} 18,524$ (FTC 1969). Eric Schnapper, of the NAACP Legal Defense and Education Fund, Inc., New York City, had submitted comments suggesting stricter disclosure requirements in the Chrysler consent order. Although the staff initially disapproved Schnapper's recommendations, the commissioners subsequently accepted them. Telephone interview with Chris White, Office of FTC Commissioner Mary Gardiner Jones, Aug. 1971. Of the Fund's efforts in general before the FTC, Mr. Schnapper has noted:

Over the past two years, I would estimate, the Legal Defense Fund . . . has sought modifications of perhaps half a dozen orders, sought half a dozen trade regulations and filed half a dozen complaints against specific merchants. I have not fully resolved in my own mind whether this is worth continuing. Where it felt it had jurisdiction, the FTC has agreed to investigate the complaints but I have yet to see the results. None of the requested regulations has been promulgated. They aren't so much killed as just missing in action. Requests for modifications of [consent] orders have been rejected for a variety of reasons.

Letter from Eric Schnapper to the University of Pennsylvania Law Reviez, Sept. 13, 1971, on file in Biddle Law Library, Univ. of $\mathrm{Pa}$. Law School. Cf. Letter from Joachim Volhard, Office of FTC Commissioner MacIntyre, to the University of Pennsylvania Law Review (undated), on file in Biddle Law Library, Univ. of Pa. Law School: "Very rarely is a consent order which has been provisionally accepted by the Commission re-executed upon receipt of comments."

598 SOUP, Inc. v. FTC, No. 24,476 (D.C. Cir., filed July 24, 1970). For a discussion of the availability of judicial review for parties other than respondents, see notes 698-706 infrn \& accompanying text. 
bowl of its soup depicted in advertisements to create the illusion that the soup contained more solid ingredients than it actually did. ${ }^{599}$ The Commission had negotiated and provisionally accepted a consent order prohibiting Campbell from further engaging in such practices. ${ }^{600}$ During the thirty-day period when the order was of public record, SOUP filed motions ${ }^{601}$ for disclosure, for an extension of time in which to comment, for leave to file one copy of documents rather than the twenty required by the rules, ${ }^{602}$ for withdrawal of the provisional acceptance, and for intervention, none of which is contemplated by the rules for informal enforcement procedures.

The Commission, however, granted the extension, permitted filing of one copy of SOUP's documents, and provided for oral argument on the issues of the need for an evidentiary hearing to determine the appropriateness of the remedy SOUP urged and of SOUP's right to intervene in such a hearing. ${ }^{603}$ After oral argument, the Commission granted SOUP discovery of some of the documents it had requested and permitted it to submit further written statements. ${ }^{604}$ In the end, the Commission accepted the agreement as negotiated, denied the request for an evidentiary hearing, and granted SOUP a free copy of the transcript. $^{\text {e05 }}$ SOUP had urged throughout that only the additional remedy of affirmative disclosure of prior deceptive advertising-forcing the respondent to wear a "scarlet letter"-would dissipate residual deception resulting from Campbell's misrepresentation. ${ }^{606}$ Petitioning for review of the order, SOUP argued that, although it had been allowed to raise the question whether the corrective remedy it proposed was necessary to protect the public, the Commission erred in not holding an evidentiary hearing, or, in the alternative, in not withdrawing the order

599 Campbell Soup Co., [1967-1970 Transfer Binder] Trade Reg. Rep. II 19,261, at 21,422 (FTC 1970).

600 Id. at 21,421 .

601 Id. at 21,422 .

60216 C.F.R. $\$ 4.2(\mathrm{c})(1971)$.

603 Brief for Petitioner at 14 , SOUP, Inc. v. FTC, No. 24,476 (D.C. Cir., filed July 24, 1970). Commissioner Elman pointed out strikingly the conceptual difficulties such concessions presented under the current rules:

If the Commission should approve the consent order [in the Campbell case] which is now under consideration we would simultaneously issue that order with the issuance of a formal complaint. . . That is the procedure. The proposed complaint would become a formal complaint, and at the precise moment that it was issued, the Commission would also be issuing a final order. So that if you have any standing to intervene, it would be in that flicker of a second between the issuance of the complaint and the issuance of a cease and desist order.

Transcript of hearing on motion by SOUP to intervene, File 69-2-3061, Feb. 5, 1970, at 11 .

604 Brief for Petitioner at 14, SOUP, Inc. v. FTC, No. 24,476 (D.C. Cir., filed July 24, 1970). See Letter from Joseph W. Shea, Secretary, FTC, to Aaron Handleman, member, SOUP, Inc., Feb. 24, 1970, copy on file in Biddle Law Library, Univ. of Pa. Law School.

605 Brief for Petitioner at 14, SOUP, Inc. v. FTC, No. 24,476 (D.C. Cir., filed July 24,1970 ).

606 See note 669 infra. 
and initiating formal adjudicative proceedings. ${ }^{607}$ Dissenting from the Commission's disposition of the case, Commissioner Elman noted:

Issues of such large importance to the public should not be "settled" on the basis of respondents' acceptance of a consent order whose adequacy has been seriously challenged by responsible representatives of the public interest. ${ }^{608}$

That the issue raised by SOUP was indeed of large public importance is suggested by the Commission's subsequent experiments with the affirmative disclosure remedy. ${ }^{609}$ An agency necessarily has broad discretion in choosing the type and scope of remedial orders, but that choice is reviewable for an abuse of discretion or for the failure to consider relevant policy issues. ${ }^{610}$ The question raised in the petition for review is the degree of control third parties should have over informal proceedings once such issues arise. The Commission's apparently unprecedented grant of privileges to SOUP was certainly adequate to bring the issue into sharp relief, but should groups like SOUP be allowed extensive privileges whenever such issues are present in consent order negotiations, and should SOUP in Campbell have been allowed to do more? SOUP did not purport to challenge the Commission's discretion to determine ultimately the adequacy of the order to protect the public interest; rather, it argued that the Commission had not built a sufficient factual basis upon which to exercise an informed discretion ${ }^{611}$ and that only an evidentiary hearing or formal adjudicative proceeding would supply that basis. Its attack went primarily to the adequacy of the procedure by which the order was accepted, not the substance of the order itself, thus avoiding the question who may seek review of such an order. ${ }^{612}$ Subtle though that argument be, the obvious result would be to set aside or at the very least delay the effectiveness of the negotiated order. SOUP's petition for review of the Campbell order raises the question whether that order is currently enforceable; ordinarily, only a final order is enforceable, and an order does not become "final" if a timely petition for review is filed. ${ }^{\text {} 13}$ The answer may depend upon whether third parties may seek review at all of enforcement orders, either in the informal or adjudicative context. Unless the

607 Brief for Petitioner at 19-20, SOUP, Inc. v. FTC, No. 24,476 (D.C. Cir., filed July 24, 1970).

608 Campbell Soup Co., [1967-1970 Transfer Binder] Trade REg. Rep. \19,261, at 21,425 (FTC 1970).

609 See note 668 infra \& accompanying text. Cf. Responses, supra note 30, at 133-34 (statement of Comm'r Philip Elman).

010 See Jacob Siegel Co. v. FTC, 327 U.S. 608 (1946). Cf. Magnaflo Co. v. FTC, 343 F.2d 318 (D.C. Cir. 1965).

611 Brief for Petitioner at 19-20, SOUP, Inc. v. FTC, No. 24,476 (D.C: Cir., filed July 24, 1970).

612 See notes 698-706 infra \& accompanying text.

61315 U.S.C. $\$ 45(\mathrm{~g})$ (1970). 
Commission's prosecutorial discretion-its control over the allocation of prosecutorial resources throughout the enforcement program-is to be curtailed to the extent of requiring an evidentiary hearing or formal adjudication whenever such issues arise and of permitting judicial review of the outcome, it must be left to the Commission to decide whether additional or alternative proceedings are desirable.

Participation in the consent order procedure, even to the extent allowed SOUP in the Campbell case, might significantly reduce one important incentive for prospective respondents to participate in that procedure-the confidentiality and protection from injurious publicity. The prospect of extensive public discussion of the adequacy of the provisionally accepted order may be just as distasteful to a prospective respondent as the prospect of trial publicity, and he may therefore be less hesitant to put the Commission to the delay and expense of proving its case. A partial solution to the problem of maintaining confidentiality while encouraging public comment might incorporate the following procedure: the Commission might make public a statement of its intention to issue a complaint regarding a specified practice without identifying the prospective respondent, or, in the alternative, issue the actual complaint. Bargaining over the order could still proceed in confidence, while third parties could make general comments on the complaint, proffer special expertise, and propose remedies appropriate to the specified practice, prior to the issuance of the provisional order. ${ }^{614}$ Information obtained in this manner would be made available to the bargaining parties during negotiations and would be more likely to influence the formulation of the order. After the prospective respondent has made its final offer of an order, the Commission might hold confidential hearings similar to those utilized in its investigative proceedings ${ }^{615}$ to permit third parties to present evidence and argument regarding the adequacy of the order. Third parties participating in such hearings would, of course, have to respect their confidentiality.

These methods of supplementing the existing provision for public comment on provisional orders would still not provide the discovery and evidentiary hearing requested by SOUP in Campbell. Presumably, much of the information SOUP desired would have been found in the Commission's investigatory file on the prospective respondent and therefore would have fallen within the exemption of the Freedom of Information Act for "investigatory files compiled for law enforcement purposes except to the extent available by law to a party other than an agency." ${ }^{616}$ The classification may not be used indiscriminately to

614 "[P]re-order citizen participation would be more meaningful in the shaping of an order. As far as I can see, there would be no compelling reason why such a procedure could not be instituted." Letter from Joachim Volhard, Office of FTC Commissioner MacIntyre, to the University of Pennsylvania Law Revieze (undated), on file in Biddle Law Library, Univ. of Pa. Law School.

615 See 16 C.F.R. $\$ 2.8$ (1971).

6165 U.S.C. \$552(b) (7) (1970). See generally Davis, The Information Act: A Preliminary Analysis, 34 U. CHI. L. REv. 761, 799-800 (1967). 
conceal information, but an adjudicative proceeding need not be "imminent" for the exemption to become operative. ${ }^{617}$ While it is debatable whether the threat of an adjudicative proceeding is "imminent" after the issuance of a provisional consent order, "the prospect of enforcement proceedings" might be "concrete enough to bring into operation the exemption for investigatory files." ${ }^{618}$ Indeed, that prospect would be heightened by allowing greater participation by third parties in the negotiation and acceptance of consent orders. In general, the FTC has not liberally permitted discovery. ${ }^{619}$ Such discovery may be vitally needed by a third party who wishes to challenge the adequacy of a consent order (or, for that matter, a cease and desist order resulting from an adjudicative proceeding) on other than broad policy grounds. Even if the third party claims expertise or a novel legal theory as a ground for intervention, he may yet require data available only from the files of the Commission or the proposed respondent to support his arguments. The Commission's rules for investigations ${ }^{620}$ and for adjudicative proceedings ${ }^{621}$ provide adequate protection against abuse of discovery and could easily be adapted to consent order proceedings. Although the Commission's grant of discovery in Campbell was characterized by one of SOUP's advocates as niggardly, ${ }^{622}$ it apparently presented no conceptual difficulties despite the absence of a rule providing for discovery in that context. There would seem no reason, apart from the concern for maintaining confidentiality and avoiding adjudication, to deny discovery limited to the grounds on which a provisional consent order is challenged.

SOUP's request for an evidentiary hearing does, however, create conceptual difficulties. Certainly there is no provision for such a hearing in the current rules. Presumably, the particularity of inquiry of such a hearing would approach that of an adjudicative proceeding. While the confidential pre-order hearing on the complaint and the range of possible remedies suggested above would focus on broad policy issues, an evidentiary hearing would arguably focus upon the conduct of the individual respondent. To the extent that this is true, the proposed respondent would likely demand the full procedural rights of a party to an adjudicative proceeding. The prospect that such an evidentiary

617 Bristol-Myers Co. v. FTC, 424 F.2d 935 (D.C. Cir. 1970).

618 Id. at 939 ; see Project, supra note 495, at 180-81.

019 See Fellmeth, The Freedom of Information Act and the Federal Trade Commission: A Study in Malfeasance, 4 HARV. CTV. RIGHTS-Crv. LIB. L. REv. 345 (1969); Gellhorn, The Treatment of Confidential Information by the Federal Trade Commission: Pretrial Practices, 36 U. CHI. L. Rev. 113 (1968); cf. Lewis, Discovery Techniques and the Protection of Confidential Data in FTC Proceedings, 21 AD. L. REv. 457, 460-64 (1969). See generally Tomlinson, Discovery in Agency Adjudication, 1971 DUKE L.J. 89.

62016 C.F.R. $\$ \$ 2.7-.12$ (1971).

621 Id. $\$ \S 3.32-.37$.

622 Interview with Geoffrey Cowan, Center for Law and Social Policy, in Washington, D.C., Sept. 27, 1971. 
hearing might be held after the prospective respondent had made its final offer of a consent order, but before the Commission had accepted it, might lead the respondent to forego informal negotiations in favor of adjudication.

The privileges granted SOUP in the Campbell case might be viewed as the logical concomitants of the privilege to comment upon provisional consent orders. The suggestions above for expanding that privilege to include pre-order comment and a confidential hearing are intended to provide the Commission with more information on broad issues of policy without encroaching upon its prosecutorial discretion. To allow third parties or an independent agency ${ }^{623}$ to challenge consent orders by initiating an evidentiary hearing or an adjudicative proceeding, however, might effectively curtail that discretion and make the Commission's allocation of enforcement resources even less efficient. ${ }^{624}$

A similar problem arises in the enforcement of the Clayton Act by the Department of Justice. Formal intervention by third parties to challenge consent decrees in those antitrust enforcement proceedings had been fairly consistently denied. ${ }^{625}$ The one important case which reached a contrary result was Cascade Natural Gas Corp. v. El Paso Natural Gas $C_{0 .}{ }^{626}$ In an earlier related case, the Supreme Court found that an acquisition by E1 Paso violated section 7 of the Clayton Act and ordered divestiture. ${ }^{627}$ When the relief subsequently framed by the Department of Justice and E1 Paso did not include the divestiture contemplated by the Court, a major consumer, a competitor, and the State of California all sought intervention in the proceeding. The Court held intervention should have been granted as of right. Subsequent cases have tended to limit the holding of El Paso to its facts. ${ }^{628}$ In

623 See notes 319-20 supra \& accompanying text.

${ }^{624}$ Cf. ABA ReporT, supra note 583, at 27-28:

[I]n terms of a percentage of its total budget, the FTC was spending in 1968 and 1969 about one-half as much on merger enforcement as it had been spending in 1959. This reduction took place during a period when the United States. . was undergoing the greatest surge of merger activity in its history.

Similarly . . the FTC has not seen fit to divert resources from other uses in order to carry out effective monitoring [of mass media advertising] or compliance [by firms that had previously entered into assurances of voluntary compliance or informal corrective procedures].

Sce generally Elman, supra note 29.

625 See Shapiro, supra note 37, at 743-44 (1968); Kaplan, Continuing Work of the Civil Committee: 1966 Amendments of the Federal Rules of Civil Procedure (I), 81 HaRv. L. Rev. 356, 403-07 (1967).

626 386 U.S. 129 (1967) ; cf. United States v. First Nat1 Bank \& Trust Co., 280 F. Supp. 260,263 (ED. Ky. 1967), aff'd mem. sub nom. Central Bank \& Trust Co. v. United States, 391 U.S. 469 (1968) (antitrust case granting intervention to a stockholder and a competitor after Government failed to appeal; district judge found "about a ninety per cent capitulation" by the Government in its role as defender of the public interest).

627 United States v. El Paso Natural Gas Co., 376 U.S. 651 (1964).

628 See, e.g., United States v. Automobile Mfrs. Ass'n, 307 F. Supp. 617 (C.D.

Cal. 1969), aff'd mem. sib nom. City of New York v. United States, 397 U.S. 248 
United States v. CIBA Corp., ${ }^{629}$ Judge Frankel, reviewing these cases, noted that "the fact that a mandate of the Supreme Court had been disregarded was a matter of consequence in [El Paso]," ${ }^{630}$ and suggested the following test for intervention: "the interest justifying intervention as of right in an antitrust suit brought by the United States must be substantial, must lie at the center of the controversy, and must be shown clearly, in the language of the Rule, to be less than 'adequately represented' by the Department of Justice." ${ }^{631}$

Of course, El Paso involved a proceeding to frame relief and was decided under the Federal Rules of Civil Procedure and not section 11(b) of the Clayton Act ${ }^{632}$ or section $5(b)$ of the Federal Trade Commission Act, ${ }^{033}$ which govern formal FTC adjudicative proceedings. Furthermore, the FTC employs consent orders in many enforcement proceedings unrelated to the Clayton Act. ${ }^{634}$ Despite these distinctions, the underlying problem remains : what of cases where an FTC consent order fails to implement, not a previous holding of the Supreme Court, but the clear mandate of a statute or Commission rule, and where the interests affected are not those of major utilities, corporate consumers, and competitors, but those of individual consumers? Perhaps the short answer is that, if El Paso is not an aberration, the present concern for conserving enforcement resources through use of informal proceedings should give way to a recognition that more resources should be provided, so that formal adjudication of matters affecting the interests of large segments of the public or matters involving broad issues of policy may be obtained. ${ }^{635}$

A recent comment ${ }^{636}$ has explored the role of nonparty participation in antitrust proceedings brought by the Department of Justice to frame consent decrees. The comment concludes that nonparties "are

(1970) (intervention denied where main goal was to compel litigation of the case to judgment, which then might be used as a basis for intervenors' private treble damage actions); United States v. Western Elec. Co., 5 TRADE REg. REP. (1968 Trade Cas.) I 72,415 '(D.N.J. 1968), aff'd mem. sub nom. Clark Walter \& Sons, Inc. v. United States, 392 U.S. 659 (1968) (motion to intervene filed 12 years after entry of consent decree denied); United States v. Blue Chip Stamp Co., 272 F. Supp. 432 (C.D. Cal. 1967), aff'd me1n. sub nom. Thrifty Shoppers Scrip Co. v. United States, 389 U.S. 580 (1968) (motions to intervene denied as untimely); United States v. Aluminum Co. of America, 41 F.R.D. 342 (E.D. Mo. 1967), appeal dismissed mem. sub nom. Lupton Mfg. Co. v. United States, 388 U.S. 457 (1967) (motion to intervene filed over 2 years after final order of divestiture denied).

62950 F.R.D. 507 (S.D.N.Y. 1970).

$630 \mathrm{Id}$. at 512 .

631 Id. at 513 .

63215 U.S.C. $\$ 21$ (b) (1970); see notes 682-90 infra \& accompanying text.

63315 U.S.C. $\$ 45$ (b) (1970).

634 Cf. notes 584-88 supra. \& accompanying text.

635 Cf. note 624 supra; E. Cox, R. FELLMETh \& J. Schulz, The Nader Report on the FEDERAI Trade CoMrMissron 57-71 (1969). See also Responses, stipra note 30 , at 122, 129, 135-36 (Statement of Comm'r Phillip Elman criticizing the secrecy of consensual agreements).

630 Comment, Private Participation in Department of Justice Antitrust Proceedings, 39 U. CHI. L. REV. 143 (1971). 
able to direct successful challenges to substantive shortcomings of these decrees and, in effect, to take appeals from adverse rulings-all while remaining technically outside of the litigation." ${ }^{637}$ It notes that nonparties participated often in the role of amicus and that therefore granting formal intervention would not contribute to delay or prejudice to the original parties, and would not generate additional litigation. ${ }^{638}$ It analyzes a number of procedural devices the courts have devised to accommodate the special nature of the judicial proceedings with such participation that are not directly relevant to the procedures the FTC employs, but which do demonstrate the ingenuity that can be brought to bear "to produce a thorough examination of the issues without impairing the utility of the consent decree for the parties." 639 The comment approves of such devices, but proposes as an alternative the following scheme for formal intervention:

Leave to intervene would be granted at the discretion of the court and would be limited to as narrow a substantive compass as possible. Procedural rights would be afforded as required for a full examination of the underlying controversy, including if necessary the right to discovery and compulsory process, subject in turn to the litigants' alternative right to withdraw their consent from the settlement. The power to block entry of a consent decree or other settlement agreeable to the original parties and the court would be withheld, but the right to appeal from such a judgment would be retained. ${ }^{640}$

The FTC in the Campbell case indicated little willingness to experiment with informal participation in its consent order program. While the procedural mechanisms the federal judiciary has developed are not directly apposite, the underlying attitude toward the potential contribution of nonparties clearly is, especially in light of the fact that public interest groups have not yet been among the nonparties participating. How public interest representation may be procedurally implemented in the context of FTC consent orders is one question awaiting resolution in the pending Campbell appeal.

\section{Formal Adjudicative Proceedings}

Formal adjudicative proceedings are essentially adversary in nature and may lead to the imposition of substantial penalties. ${ }^{641}$ To the extent that the two-party contest sharpens presentation of the issues

637 Id. 169.

638 Id. 153.

639 Id. 160.

$640 I d .176$.

641 See ABA REPORT, supra note 583, at $8 \& \mathrm{n} .20$. These civil penalties may be imposed by a court for violation of a final FTC order. 
and thereby makes decision easier, and that intervention by third parties delays enforcement and unfairly subjects the respondent to different and perhaps conflicting lines of attack, such intervention should be limited. Formal adjudicative proceedings, however, serve also as vehicles for the formulation of Commission policy. ${ }^{62}$ Although there have been indications of increased reliance on trade regulation rules, ${ }^{643}$ redefinitions of unlawful conduct and appropriate remedies are most likely to be made in the adjudicatory context. To the extent that broad questions of policy are decided in that context, intervention by parties affected by these policies should be allowed and encouraged.

The Federal Trade Commission Act makes the following provision for intervention:

Any person, partnership or corporation may make application, and upon good cause shown may be allowed by the Commission to intervene and appear in said proceeding by counsel or in person. ${ }^{644}$

The Commission's procedural rules themselves provide no more explicit standard for "good cause shown":

The hearing examiner or the Commission may by order permit the intervention to such extent and upon such terms as are provided by law or as otherwise may be deemed proper. ${ }^{645}$

Motions to intervene in adjudicative proceedings have been viewed with disfavor by the Commission. Potential intervenors have sought, but have been denied, intervention on a number of grounds: the existence of a similar case on the docket involving the potential intervenor

642 See Robinson, supra note 191, at 490-96.

643 See 16 C.F.R. $\$ 1.12$ (1971); cf. K. Davis, DisCretionary Justice 74-77 (1969) (FTC "Cigarette Rule" on hazards of smoking); Shapiro, supra note 198, at 964-67 ("Cigarette Rule").

Problems associated with intervention might conceivably arise in the context of a trade regulation rule hearing. The FTC usually commences such hearings on a complaint, although it may act sua sponte. Any interested person may give oral evidence; only the Commission staff, however, may cross-examine. Because one purpose of such hearings is to build a record that can withstand possible judicial scrutiny, interested persons might argue for cross-examination privileges to augment their impact on the record. Telephone interview with FTC Commissioner Mary Gardiner Jones, Aug. 1971. The hearings themselves, of course, are not required by $\$ 4(\mathrm{~b})$ of the Administrative Procedure Act, 5 U.S.C. $\$ 553$ (c) (1970). For proposals to make the FTC's rulemaking authority more explicit, see SENATE CoMr. on Comarerce, Consumer Protection Act: Report on S. 3201, S. Rep. No. 91-1124, 91 st Cong., 2d Sess. 13, 22, 51 (1970). As Chairman Weinberger noted, "the Commission believes that its power to issue substantive rules should be made more explicit. Any doubts about its rulemaking authority should be clarified and removed. Any possible ambiguity in its present rulemaking authority between its Labeling Acts and the Federal Trade Commission Act should be eliminated." Id. 51.

This development may well have been halted, at least within the existing statutory context, by the recent and surprising holding that the FTC has no statutory authority at all to issue trade regulation rules. See National Petroleum Refiners Ass'n v. FTC, 40 U.S.L.W. 2671 (D.D.C. Apr. 4, 1972).

644 15 U.S.C. $\$ 45(\mathrm{~b})$ (1970). See 15 U.S.C. $\$ 21$ (b) (1970).

645 16 C.F.R. $\$ 3.14$ (1971). 
as respondent; ${ }^{646}$ involvement of the potential intervenor in a similar proceeding currently pending; ${ }^{647}$ the suffering of injury from unfair competition; ${ }^{648}$ and the fact that the potential intervenor proposed to advance legal theories not raised by the Commission's complaint counsel or the respondent. ${ }^{649}$ It has long been clear that private injury per se confers standing neither to initiate nor to intervene in an adjudicative proceeding. ${ }^{650}$ Underlying the reluctance to grant intervention is the theory that the Commission

acts only in the public interest, any protection afforded private persons being only incidental, and it must be ever vigilant against the possibility of its processes being used to further the private interests of any party. ${ }^{651}$

Because the Commission itself acts as prosecutor, the need for allowing "private attorneys general" ${ }^{652}$ to initiate actions would seem to be substantially diminished, although not obviated altogether. The need to prevent the Commission from becoming a forum for private damage suits by competitors, which seems the policy behind the restrictive provisions for judicial review, ${ }^{653}$ should not lead to the exclusion at the Commission level of groups asserting "private" interests held by large segments of the public. The legislative history may disclose an intent to foreclose judicial review to certain classes of parties, but that does not necessarily imply the intent to foreclose participation in the proceedings themselves. If it did, why was any provision at all made for intervention? Even if the Data Processing-Welfare Rights rationale ${ }^{654}$

646 Max Factor, Inc., No. 7717, Order Denying Motion to Intervene (FTC, May 11, 1970).

647 Berger Watch Co., 56 F.T.C. 1655 (1969) (application denied as "untimely"). 648 Grand Caillou Packing Co., No. 7887, Order Denying Motion to Intervene (FTC, Nov. 8, 1962).

649 Kennecott Copper Corp., 3 Trade Reg. Rep. II 19,281 (FTC 1970); see notes $682-90$ infra \& accompanying text.

650 FTC v. Klesner, 280 U.S. 19, 25-26 (1929). See notes $682-707$ infra \& accompanying text. On the other hand, states and other governmental units have occasionally been allowed limited intervention, often on behalf of respondents representing industries of economic importance to their particular regions. See, e.g., Florida Citrus Mut., 53 F.T.C. 973 (1957) ; Soap Lake Prods. Corp., 33 F.T.C. 999 (1941). Such intervention is possibly allowed merely as a matter of political accommodation, for trade associations seeking to advance similar arguments have been denied intervention. See, e.g., Campbell Taggert Associated Bakeries, Inc., 62 F.T.C. 1494 (1963) ; Florida Citrus Mut., supra.

651 Wilson Tobacco Bd. of Trade, 52 F.T.C. 1148, 1151 (1956). Compare the role of a private person filing an unfair labor practice charge under the National Labor Relations Act, 29 U.S.C. \$160 (1970), and 29 C.F.R. \$\$102.9-.59 (1971). The NLRA recognizes the existence of private rights within the statutory scheme. Iocal 283, UAW v. Scofield, 382 U.S. 205, 218 (1965). If a complaint is issued on the basis of such a charge, the charging party may participate in the hearings as a "party." If the Board dismisses the complaint, he may obtain judicial review and may intervene in appellate review of an NLRB order initiated by the unsuccessful party. Id. at $219-21$.

652 See note 53 supra \& accompanying text.

653 See notes 692-706 infra \& accompanying text.

654 See notes 7-12, 57-70, 94-113 supra \& accompanying text. 
for requiring participation below to the extent necessary to make the right of review effective does not apply, a court might still require participation on the ground, for example, that some important policy position had not been adequately represented and that the determination was not therefore based upon substantial evidence.

This Comment previously outlined some reasons why agencies might not adequately represent each of the interests held by large segments of the public affected by its decisions. ${ }^{655}$ The adversary nature of FTC adjudicative proceedings heightens that problem: complaint counsel may well lack the time, resources, and tactical flexibility to assess fully the impact of challenged conduct on consumers, the economy, or the environment and to develop, accordingly, new theories of liability or appropriate remedies on a case-by-case basis. ${ }^{656}$ These are areas in which participation by third parties, including public interest groups, could contribute most. Informal methods of participation in adjudicative proceedings by third parties are not unusual. Trade associations apparently have close ties with the Commission and complaint counsel. ${ }^{657}$ Nothing prevents third parties from working informally with counsel for the FTC or respondent in the preparation of its case. This channel is open to a public interest group in those instances where it might wish to aid or oppose a respondent by furnishing suggestions, theories, or factual data.

The FTC has recently experimented with expanding the scope of formal participation in adjudicative proceedings. In Firestone Tire \& Rubber Co., ${ }^{658}$ SOUP was allowed to intervene in forma pauperis in an adjudicative proceeding charging Firestone with deceptive advertising regarding the pricing and safety of its tires. In granting SOUP's request to file an interlocutory appeal ${ }^{659}$ from the hearing examiner's denial of intervention, the Commission stressed that, by allowing limited intervention, it was "beginning a delicate experiment, one requiring caution and close observation" and that its action "should [not] be construed as a permanent or irreversible policy decision." "600 The Commission directed the hearing examiner to permit intervention for the purposes of

(1) presenting, at the conclusion of complaint counsel's casein-chief, relevant, material, and non-cumulative evidence on the issue of whether the proposed order to cease and desist adequately protects the public interest;

655 See notes $157-60$ supra \& accompanying text.

656 Cf. ABA Report, supra note 583, at 12-15, 78-80.

657 See, e.g., Whiting, The Role of a Trade Association When the Government Looks to Its Industry, 13 ANTrTRUST BuLc. 567, 586-87 (1968); cf. notes 683-87 infra \& accompanying text.

658 3 Trade Reg. Rep. $\mathbb{1 9}$ 19,373 (FTC 1970). See Project, supra note 495, at 228-38.

059 See note 260 supra \& accompanying text.

6603 TRADE REg. REP. $\pi 19,373$, at 21,502. 
(2) presenting, with respect to said issue, briefs and oral argument in such manner and to such an extent as the examiner may deem reasonable; and

(3) exercising, with respect to said issue, such discovery rights as the examiner shall deem reasonable and necessary. ${ }^{661}$

In the course of the subsequent hearing, SOUP was not allowed to address the issues of deceptive advertising and pricing; its intervention was limited to the appropriateness of the proposed remedy, although on that issue it was apparently allowed to cross-examine witnesses. ${ }^{62}$ Soon after the Commission granted SOUP limited intervention, the examiner granted similar privileges to the Association of National Advertisers, Inc., (ANA) to address the same issue. SOUP argued, as it had in the Campbell case, that "affirmative disclosure" should be part of the remedy in order to counteract the residual effects of Firestone's advertising. The examiner concluded that affirmative disclosure was inappropriate, ${ }^{663}$ and an appeal is presently before the Commission.

Despite its failure to convince the examiner, SOUP did have a significant opportunity to supplement the record. In granting intervention the Commission suggested five criteria that should be considered in future cases: (1) the applicant's "desire to raise substantial issues of law or fact which would not otherwise be properly raised or argued"; (2) the nature of the issues (that they be "of sufficient importance and immediacy to warrant an additional expenditure of the Commission's limited resources on a necessarily longer and more complicated proceeding") ; (3) the applicant's potential contribution to a just resolution of the issues; (4) the need for expedition in obtaining compliance with the law; and (5) "the possible prejudice to the original parties." 684 At the same time, the Commission emphasized that no precise standard could be formulated but that, because "the FTC has a built-in public interest prosecutor in all of its proceedings," there must be a "substantial showing of special circumstances justifying intervention." ${ }^{665}$ The adversary nature of FTC proceedings and special

$661 \mathrm{Id}$.

662 Interview with Geoffrey Cowan, Center for Law and Social Policy, in Washington, D.C., Sept. 27, 1971.

6633 Trade Reg. Rep. $\llbracket 19,373$.

664 Id. at 21,501-02 (emphasis in original).

$665 \mathrm{Id}$. at 21,502 . For a recent case in which intervention seems to have been granted in disregard of the tentative guidelines established in Firestone, see American Gen. Ins. Co., 3 Trade Reg. Rep. II 19,915 (FTC, Feb. 11, 1972). In dissent, Commissioner Mary Gardiner Jones noted:

It is obvious that the factors enumerated in the Commission's Firestone opinion are not ones for determination by its hearing examiners and quite clearly do not simply involve housekeeping matters associated with the conduct of the hearings. The addition of a party is and always has been regarded as an issue on which only the Commission can finally rule. Moreover, so long as rulings on intervention embrace in some significant respect issues of resource allocation and delicate weighing of priorities and long range 
problems concerning the reviewability of FTC decisions ${ }^{666}$ make the argument from Data Processing and Welfare Rights-that one within the zone of interests sought to be protected by the relevant statute has a right to participate in agency proceedings to the extent necessary to make the right of review effective ${ }^{667}$-of limited applicability.

In Firestone the Commission indicated interest in exploring "affirmative disclosure" in a case that involved a "public safety danger" because "this issue and this type of case is high on the list of our own priorities." 668 Perhaps its willingness to allow intervention to SOUP, and the examiner's extension of similar privileges to ANA, reflected a realization that the issue, despite the adversary context in which it arose, would be more properly decided in the rulemaking context, and that wider participation by third parties should be permitted in recognition of that fact. On the other hand, perhaps the Commission sought to forestall industry opposition by allowing the issue to be raised in this more indirect manner. Whatever the Commission's motives in Firestone, the remedy originally urged by SOUP has subsequently been obtained in other cases by complaint counsel without participation by third parties. ${ }^{69}$ It remains to be seen whether future intervention will require the presence of and be limited to similar issues arguably more appropriate for rulemaking. Allowing intervention limited to such issues in the adjudicative context may be a compromise, however inadequate, between the Commission's desire to retain the flexibility in formulating policy and the control complaint counsel has over the issues that the adjudicative context affords, and its apparent recognition of the value of broadened participation. The Commission has not yet clarified the functions it thinks intervention should serve, nor has it provided more precise standards for its grant or denial.

Since intervention in Firestone was granted, the Commission has referred the problem of formulating more precise standards to an advisory committee on rules and practices ${ }^{670}$ which has not yet made its

benefits to the public interest, the Commission cannot duck responsibility for the ultimate decision by hiding behind its examiner's ruling as it has tried to do in the instant case.

Id. at 21,931 .

606 See notes 692-699 infra \& accompanying text.

607 See notes 7-12, 57-70, 94-113 supra \& accompanying text.

6683 Trade Reg. Rep. $\| 19,373$, at $21,502$.

669 See Note, "Corrective Advertising" Orders of the Federal Trade Commission, 85 HaRv. L. REv. 477 (1971).

670 See Resolution authorizing an Advisory Council on FTC Rules of Practice and Procedure, 36 Fed. Reg. 4728 (1970); FTC News Release (May 27, 1970). The Commission invited public comment on the proposed revision, FTC News Release (July 15, 1970). In response, Bruce Terris, a Washington, D.C., attorney, submitted "without success" proposed revisions which would (1) provide intervention with full party status as of right in adjudicative proceedings to any person or competent representative of a class which meets the Data Processing test; (2) provide public disclosure of assurances of voluntary compliance, see notes 587-89 sipra \& accompanying text, and opportunity for public comment and for a hearing if a substantial question of fact as to the appropriateness or adequacy of the assurance is raised by 
recommendations. ${ }^{671}$ The proposed model intervention rules ${ }^{672}$ and rule 24 of the Federal Rules of Civil Procedure, which grants intervention as of right to private parties whose interests may be affected by the proceeding and who are otherwise unrepresented, ${ }^{673}$ are overly broad and therefore unhelpful in formulating a standard that takes into account the prosecutorial role of complaint counsel and the jeopardy that attaches to respondents in FTC enforcement proceedings.

Even if the tautology that complaint counsel represents all affected interests because he acts in the "public interest" can be broken, there remain further objections to allowing intervention by parties whose interests are potentially affected but arguably unrepresented. Former Commissioner Elman and the ABA Commission to Study the Federal Trade Commission have strongly criticized the FTC for failure to establish priorities, consistent with its limited resources, among the many types of industry activity it has authority to regulate and the many statutory prohibitions it is charged to enforce. ${ }^{674}$ If third parties were given the power to override the Commission's discretion in choosing which cases to prosecute, or, when adjudication has commenced, to usurp complaint counsel's control over trial tactics, the Commission's attempts to establish and implement such priorities might be seriously impaired, to say nothing of the potential increase in delay, which even now is one of the Commission's major problems. ${ }^{675}$ On the other hand, once adjudication has commenced and substantial questions of policy or fact are raised, there would seem to be no policy reasons against the approach suggested in Firestone. Intervention before the hearing examiner limited to those questions should be allowed, with appropriate procedural privileges, including the presentation of witnesses, crossexamination, and discovery, necessary to address those questions adequately. Some questions of policy, where underlying facts are not in dispute, might be effectively addressed through the presentation of an amicus brief; where facts are in dispute, however, intervenors must be allowed procedural privileges sufficient to enable them to present their evidence bearing on those facts.

While it might be adequate for the presentation of general legal or policy arguments, intervention before the Commission without previous participation before the hearing examiner would not present the opportunity for the participant to contribute to the record evidence or

a party who would have the right to intervene in an adjudicative proceeding; and (3) provide a similar hearing when a substantial question as to the appropriateness or adequacy of a proposed consent order is raised. Letter with copy of proposed rules from Bruce J. Terris to University of Pennsylvania Law Review, Sept. 14, 1971, on file in Biddle Law Library, Univ. of Pa. Law School.

671 Telephone interview with Theresa Schwartz, Office of FTC Commissioner Jones, Apr. 6, 1972.

672 See note 18 supra.

673 FED. R. Crv. P. 24 ; cf. notes 114-20 supra \& accompanying text.

674 See sources cited note 624 sipra.

675 See, e.g., ABA RePORT, supra note 583, at 28-32. 
expertise not otherwise available. Intervention before the Commission itself presents no great mechanical problems: at most, extra time would be expended for oral argument and consideration of additional briefs and other written submissions. This form of participation, though the easiest for the Commission to grant, may not permit the fullest possible contribution by the intervenor. Allowing intervention before the hearing examiner might, however, aggravate existing problems of delay and manageability if the privileges granted intervenors-and particularly the privilege of cross-examination-are not carefully tailored to the purposes of their participation.

Firestone leaves a number of troublesome questions unanswered. Assuming broad questions of policy or fact are raised in an adjudicative proceeding, what qualifies applicants for intervention to speak to those matters? The possession of unique expertise or access to facts not otherwise available to the Commission, such as that claimed by SOUP ${ }^{676}$ and the ANA ${ }^{677}$ in Firestone, might in itself qualify a party to intervene. Many groups whose interests may be vitally affected by a proceeding, however, may well lack expertise. The only organizations which currently could meet this requirement are trade organizations such as the ANA or broadly based public interest groups such as Consumers Union. ${ }^{678}$ Similarly, the desire to advance a legal theory which complaint counsel, for whatever reason, chooses not to utilize might be urged as a ground for intervention. ${ }^{679}$ The obvious dangers in allowing intervention on this ground are the potential unfairness to the respondent and the potential tactical restrictions on complaint counsel.

It has been suggested above that certain issues raised in the adjudicative context might more properly be treated in the rulemaking context. With respect to such issues, the objective should be to ensure representation of all interests affected by the decision, and intervention should therefore be granted more liberally. Should the sole criterion for intervention in such instances be whether the applicant's interest is

${ }^{676}$ Firestone Tire \& Rubber Co., FTC No. 8818, Motion of SOUP, Inc., for leave to intervene, for leave to proceed in forma pauperis, and for disclosure, July 29 , 1970 , at 2 .

677 Firestone Tire \& Rubber Co., FTC No. 8818, Motion of Association of National Advertisers, Inc., for leave to intervene, Nov. 24, 1970.

678 Consumers Union, a nonprofit organization chartered in 1936 under New York law, derives its income from the sale of its publications, the chief of which is Consumer Reports. Its purposes are "to provide consumers with information and counsel on consumer goods and services, to give information and assistance on all matters relating to the expenditure of family income, and to initiate and to cooperate with individual and group efforts seeking to create and maintain decent living standards." Edrtors of Consumer Reports, The Medicrne Show 4 (1970). Consumers Union supported SOUP's motion to intervene in the Campbell case. Brief for Petitioner at 3, SOUP, Inc. v. FTC, No. 24,476 (D.C. Cir., filed July 24, 1970).

679 SOUP's legal theory in Campbell and Firestone was affirmative disclosure or "corrective advertising." See notes 668-69 supra \& accompanying text. The United Steelworkers of America, in Kennecott Copper Corp., 3 TRADE REG. REP. $\pi 19,619$ (FTC 1971), appeal docketed, No. 71-1371, 10th Cir., Mar. 31, 1972, urged that the enhancement of the acquired coal company's position in the industry effected by the addition of the acquiring company's resources threatened to weaken competition in the industry. See note 689 infra \& accompanying text. 
adequately represented by existing parties? In some cases that standard would permit intervention by numerous parties who would appear to assert similar interests, but who, as a practical matter, would advance different policy positions formulated to advance those interests. Broadly based groups such as the NAACP or Consumers Union may not, because of their size and diversity of membership, reflect the interests of groups like the Black Panthers and SOUP. One criterion the Commission might use, therefore, is the "adequacy of representation" standard suggested by rule 24 of the Federal Rules of Civil Procedure. ${ }^{60}$ An applicant whose policy position relative to his interest is already adequately represented should be denied intervention. The Commission might require applicants to submit an explanation why they are not adequately represented or why their positions cannot be adequately represented simply by submitting an amicus brief and perhaps presenting oral argument. Where factual questions are intertwined with policy issues, as in the Firestone case, fuller procedural privilege will probably be required for adequate representation.

A related problem is the extent to which a broad policy issue appropriately addressed by otherwise unrepresented intervenors may be broadened still further. In Firestone, for example, should the issue of the appropriate remedy have been broadened if, independent of SOUP's contentions, another group had proposed restitution as a remedy, and still another had proposed that respondent never again be allowed to advertise the product in question? To what extent should priority in time of request for intervention or the degree to which the applicant group is established, well-organized, and well-funded be considered? Priority in application should be persuasive but not a controlling factor; otherwise, the Commission might deny participation to latecomers or poorly financed applicants in favor of better established groups like Consumers Union. To what extent could consolidation procedures such as those utilized in complex or multidistrict litigation be adapted to the agency proceeding to allow the maximum number of parties to enter with a minimum of confusion, while preserving the ability of each party to present the unique aspects of its position? ${ }^{681}$

\section{Appeals of Commission Orders}

No party denied intervention in an adjudicative proceeding had sought judicial review of that denial, before the United Steelworkers of America did so in $1970 .^{682}$ The Steelworkers attempted to intervene in a proceeding against the Kennecott Copper Company for violating

680 See notes $115-20$ supra \& accompanying text.

681 See generally Comment, Observations on the Manual for Complex and Multidistrict Litigation, 68 MrCH. L. Rev. 303 (1969).

682 United Steelworkers v. FTC, No. 24,629 (D.C. Cir., filed Sept. 15, 1970), petition for review withdrawn without prejudice (May 28, 1971). Such a development is undoubtedly related to the emergence of the Data Processing-Welfare Rights rationale. See notes 7-12, 57-70, 94-113 supra \& accompanying text. 
section 7 of the Clayton Act ${ }^{683}$ by acquiring Peabody Coal Company. ${ }^{684}$ The union was influential in calling into question the legality of the acquisition, ${ }^{685}$ and appears to have had a fairly close working relationship with complaint counsel during the trial and before the hearing examiner issued his initial decision dismissing the complaint, ${ }^{686}$ although it did not participate in the trial in any formal capacity. After the examiner had issued his opinion, the Steelworkers filed a motion to intervene as a party before the Commission in support of the complaint. The union's grounds for intervention were that it represented the interests of its one and one-quarter million members as consumers of electricity which might be impaired by a lessening of competition in the coal industry, that it was a "responsible party to assert the interest of the public in preserving full and free competition," that acquisitions such as the one it opposed had an adverse effect on labor relations (though concededly an effect outside the jurisdiction of the FTC), and, most important, that if it were denied intervention and if Kennecott won before the Commission, complaint counsel would be bound by that decision and there would be no other party to seek judicial review. ${ }^{687}$ The Commission denied the Steelworkers party status but granted permission to file a brief and present oral argument on the merits. ${ }^{688}$ The Steelworkers urged a legal argument not pressed by complaint counsel, that the acquisition would in effect combine Kennecott's resources with Peabody's and thereby enhance Peabody's relative position in the coal industry to the detriment of competitors. ${ }^{689}$ Ultimately this argument contributed to the reversal of the initial decision: the Commission ordered divestiture, ${ }^{690}$ and the Steelworkers' petition for review of the denial of intervention was mooted.

68315 U.S.C. $\$ 18$ (1970).

684 Brief for Petitioner at 2, United Steelworkers v. FTC, No. 24,629 (D.C. Cir., filed Sept. 15, 1970).

685 FTC pre-merger clearance procedures were conducted in confidence, as are negotiations for informal corrective actions, assurances of voluntary compliance, and consent orders, and were strongly criticized by Professor Davis. K. Davis, DiscreTIONARY JUSTICE 113-16 (1969). In 1969, the FTC adopted a procedure whereby provisional approvals or disapprovals of mergers or similar transactions were made public and opportunity given for submission of objections or comments. FTC News Release (May 23, 1969), discussed in 3 Trade REg. REP. 19738 (Packet No. 445, at $14-15$, dated Dec. 22, 1969) (subsequently deleted). Without such a procedure, it would be very difficult for third parties who lack the investigative resources of groups like the Steelworkers to object effectively.

686 Telephone interview with Harold D. Rhynedance, Jr., Assistant General Counsel, FTC, Aug. 1971.

687 Brief for Petitioner at 4, United Steelworkers v. FTC, No. 24,629 (D.C. Cir., filed Sept. 15, 1970).

688 Id. 5.

689 Complaint counsel argued against the acquisition on the ground that it would eliminate Kennecott as a potential entrant into competition in the coal industry. Id. 5-6.

690 Kennecott Copper Corp., 3 Trade REg. REP. $\{19,619$ (FTC 1971), appeal docketed. No. 71-1371, 10th Cir., Mar. 31, 1972. The political pressure generated by the Steelworkers arguably had as much influence on the result as the legal argument they advanced. 
The question left undecided is, who may seek judicial review of the Commission's issuance of, or failure to issue, a cease and desist order, consent order, divestiture order, or other enforcement order. SOUP in Firestone and the Steelworkers in Kennecott had, in effect, all privileges necessary to advocate their positions effectively. Such informal participation, often by way of amicus briefs, is quite common. The Steelworkers in particular consulted with complaint counsel when the case was before the examiner, and, though complaint counsel chose not to press one legal argument they favored, they themselves urged that argument before the Commission. If intervention implies, in practical terms, that a party has an adequate opportunity to be heard, then, with the exception of procedural privileges at the initial hearing which they did not seek, the Steelworkers may be said to have, in effect, intervened. In their petition for review, however, they argued that intervention implies the right to review and that the denial of intervention in their case was not a denial of any right to be heard, but rather a denial of a right to appeal; they implied, in other words, that the only functional value of formal intervention is that it carries with it the right to appeal.

Though the right to appeal or otherwise seek review of agency action may carry with it the right to intervene, ${ }^{691}$ the grant of intervention cannot in itself create a right to judicial review. The fundamental question in the Steelworkers' petition for review was not, therefore, only whether an intervenor may appeal, but whether any party other than one subject to an enforcement order may appeal.

Jurisdiction to review FTC orders is conferred by section 5 (c) of the Federal Trade Commission Act ${ }^{692}$ and the virtually identical section 11(c) of the Clayton Act. ${ }^{693}$ Section 11(c), which governed the Kennecott proceedings, provides:

Any person required by such order of the commission or board to cease and desist from any such violation may obtain a review of such order in the court of appeals of the United States for any circuit within which such violation occurred or within which such person resides or carries on business .694

In the Senate debate on the FTC Act, it was twice proposed that section 5 be amended to allow a complaining party to obtain judicial review of dismissal of his complaint, ${ }^{695}$ but the amendment was ex-

691 See notes 39-44 supra \& accompanying text.

69215 U.S.C. $\S 45(\mathrm{c})(1970)$. The provision has been characterized as one of the narrowest provisions for review of administrative action. $3 \mathrm{~K}$. DAvIs, supra note $23, \S 22.03$, at 214 .

69315 U.S.C. $\S 21$ (c) (1970).

694 Id.

695 See 51 CoNG. REc. 13,045, 13,053 (1914). 
presssly rejected in favor of the present provision. ${ }^{696}$ Senator Cummins, an opponent of the more liberal provision for review, summarized his objections as follows:

The commission is intended to enforce the law for the public welfare. It is not intended to try cases between individuals engaged in business. If you make the commission simply the original trial court as between individuals who may be interested in unfair practices in trade, you will have destroyed, in my judgment, absolutely its usefulness as a public instrumentality for the purposes of correction. ${ }^{697}$

It would appear, then, that the restrictive provision for review was intended to prevent the Commission from becoming a forum for private disputes largely involving competitors. It was early held that review of an enforcement order under the FTC Act and the Clayton Act was available only to a party subject to the order. ${ }^{698}$ Recourse to the legislative history does not resolve the question whether the intent to deny review extended beyond private parties engaged in competition with respondents to encompass groups which, like SOUP and the Steelworkers, assert the interests of large segments of the public. Congress in 1914 apparently assumed that the Commission would adequately represent the interests of the public, the sort of assumption courts today are increasingly willing to question. ${ }^{69}$ The recent phenomenon of public interest intervention could hardly have been foreseen in 1914, nor, for that matter, could a case like Kennecott, where the "private" party asserting a right to review dismissal of a complaint was a union representing the interests of its one and one-quarter million members.

An explicit grant of review to one class, without more, does not imply denial to all other classes. ${ }^{700}$ The Supreme Court has stated that "only upon a showing of 'clear and convincing evidence' of a contrary legislative intent should the courts restrict access to judicial review." 701 Absent such evidence, the provisions for review under the Administrative Procedure Act ${ }^{\mathbf{7 0 2}}$ would apply to any third party not clearly denied review. ${ }^{703}$ The vagueness of the legislative history will, of

696 Id. 13,318. In the subsequent debate on the Clayton Act, a similar amendment was offered, id. 14,223-24, but replaced at once with the present provision. Id. 14,224 .

697 Id. 13,316 (emphasis supplied).

698 Wholesale Grocers' Ass'n v. FTC, 277 F. 657 (5th Cir. 1922).

699 See notes 7-12, 94-113 supra \& accompanying text.

700 See id.

701 Abbott Laboratories v. Gardner, 387 U.S. 136, 141 (1967).

7025 U.S.C. $\$ \S 701-06$ (1970).

703 These provisions have been held to apply to respondents seeking review of FTC actions other than cease-and-desist orders; the appropriate forum was said to be the district court. See, e.g., Robertson v. FTC, 415 F.2d 49 (4th Cir. 1969); Rettinger v. FTC, 392 F.2d 454 (2d Cir. 1968). It would appear that third parties appealing similar orders under the APA would be relegated to the district court. 
course, make the determination of which parties should be allowed review a difficult one, particularly in cases where "public" and "private" interests are difficult to distinguish. ${ }^{\mathbf{7 0 4}}$ One possible pattern, however, seems clear: those parties, such as competitors, asserting a direct economic interest in the proceeding might be denied review in favor of those asserting interests shared by large segments of the public. Under this analysis, there would be no reason to deny third parties review of consent orders, as distinguished from enforcement orders resulting from adjudication, even though the party subject to the former waives his right to review. ${ }^{705}$ Moreover, review would not turn upon whether one had participated in the Commission proceedings below. ${ }^{706}$

Participation in FTC proceedings by third parties asserting broad interests and claiming extensive procedural privileges and appellate review is a very recent phenomenon which has been so far confined to the Campbell, Firestone, and Kennecott cases. The extent to which review should be denied such parties should be clarified by Congress, particularly in light of the proposed Consumer Protection Agency, which would be enabled to participate as of right in formal adjudicative proceedings. ${ }^{707}$

Thus SOUP, Inc. v. FTC, No. 24,476 (D.C. Cir., filed July 24, 1970), an attempt of a third party to appeal from a consent order, was properly before a court of appeals, while United Steelworkers v. FTC, No. 24,629 (D.C. Cir., filed Sept. 15, 1970), should have been brought in a district court. If the old holding in Wholesale Grocers' Ass'n v. FTC, 277 F. 657 (5th Cir. 1922), that only a party subject to a cease-and-desist or other enforcement order may appeal, were reaffirmed, third parties might meet the APA's requirement of being "adversely affected or aggrieved" only in that relatively small class of cases in which an enforcement order is not being challenged. The trade association in Wholesale Grocers included respondents who had sought review on their own initiative of the cease-and-desist order the association sought to challenge; the shopkeeper in FTC v. Klesner, 280 U.S. 19 (1929), was a competitor, and the dispute, as Justice Brandeis noted, 280 U.S. at 28 , was "essentially private in its nature"- the sort of dispute Senator Cummins wished to exclude from the FTC. See notes 695-97 supra \& accompanying text. Neither these cases nor the legislative history of the provisions for review clearly forecloses either the Commission's complaint counsel or a public interest intervenor from obtaining review. As a practical matter, complaint counsel will hold his peace once the Commission has decided against him. If the Commission had so decided in Kennecott, a group like the Steelworkers would have been the only party with an incentive to seek review. If it is held that such groups may obtain review under the provisions of the organic act or the Clayton Act, the appropriate forum would of course be the court of appeals. If the right to appeal were grounded on the APA, it might be argued on the basis of Robertson and Rettinger (neither of which dealt with cease-and-desist orders) that the court of competent jurisdiction is the district court. It would seem anomolous, however, to have respondents appeal enforcement orders to a court of appeals and other parties appeal to a district court (where the respondent almost certainly would move to intervene). Cf. Foti v. Immigration \& Naturalization Serv., 375 U.S. 217 (1963) ; Environmental Defense Fund v. Hardin, 428 F.2d 1093, 1099 (D.C. Cir. 1970); L. JAFFe, supra note 33, at 422 . This Comment agrees with Professor Jaffe's conclusion: "I would strive to the greatest extent possible to consolidate review in a single court." Id.

704 Cf. notes $533-47$ supra \& accompanying text.

70516 C.F.R. $\$ 2.33$ (1971).

$706 C f$. notes 39-44 supra \& accompanying text.

707 See notes 306-21 supra \& accompanying text. 


\section{Funding Public Participation}

However the Commission or the court may expand the scope of participation to be afforded third parties in FTC proceedings, the practical problem of funding must be confronted. ${ }^{708}$ In Firestone the Commission, to the extent it felt its statutory authority permitted, allowed SOUP to proceed in forma pauperis. ${ }^{709}$ The Court of Appeals for the District of Columbia Circuit subsequently denied SOUP's motion to proceed in forma pauperis on appeal, on the ground that the in forma pauperis statute ${ }^{710}$ comprehends only natural persons, and, even if it does apply to a corporation, its individual members must lack the means to pay the costs involved. ${ }^{711}$ One judge dissented from the order, maintaining that the statutory language does comprehend corporations and that to require evaluation of the personal financial resources of each of a corporation's members would disregard the corporate form, impose an unnecessarily time-consuming burden on the court, and discourage nonindigent individuals unwilling to assume personal liability for costs from joining corporations that might bring suits to promote the public interest. $^{712}$

It is the current policy of the FTC to provide counsel for indigent respondents, including corporations. ${ }^{713}$ If one criterion for permitting a third party to participate in a proceeding is the adequacy of representation of its interest by existing parties, then perhaps counsel should be provided indigent parties whose interests would otherwise be inadequately represented. The tentative standards for intervention advanced in Firestone ${ }^{714}$ emphasize the potential contribution an applicant might make to the proceeding. An indigent applicant asserting an otherwise inadequately represented interest obviously promises to contribute little, standing alone. If that applicant's interest were effectively articulated by counsel, the potential contribution would be substantially increased. If, however, the Commission itself were to provide counsel to such indigent applicants, it would have, perhaps, too much control

708 See notes 289-321 supra \& accompanying text. The following assessment of the cost to the Commission of participation in hearings gives some suggestion of the financial burden on intervenors:

It is estimated that it costs the Commission approximately $\$ 1,000$ per day of trial. This does not include the cost of preparation, briefing, time spent writing the initial decision, etc.

Letter from Joachim Volhard, Office of FTC Commissioner MacIntyre, to the University of Pentrsylvania Law Review (undated), on file in Biddle Law Library, Univ. of Pa. Law School.

709 Firestone Tire \& Rubber Co., 3 Trade Reg. Rep. $\{19,519$ (FTC 1971). 71028 U.S.C. $\$ 1915$ (a) (1970).

711 SOUP, Inc. v. FTC, 5 Trade Reg. ReP. $\llbracket 73,660$ (D.C. Cir., July 27, 1971) (order denying motion to proceed in forma pauperis).

$712 I d$.

713 American Chinchilla Corp., [1967-1970 Transfer Binder] Trade Reg. Rep. II 19,059 (FTC 1969). See Comment, Trumpets in the Corridors of Bureancracy: $A$ Coming Right to Appointed Connsel in Administrative Adjudicative Proceedings, 18 U.C.L.A.L. REv. 758, 766-67 (1971).

714 Notes 658-59 supra \& accompanying text. 
over determining whether their interests were worthy of representation and how staff counsel should present their cases. Alternative approaches might better insure independent control of such applicants' cases. ${ }^{715}$

Short of providing counsel, the Commission could take other steps to alleviate the financial burden on indigent intervenors. It could, as it did in Campbell, ${ }^{716}$ provide a free transcript and, as in Firestone, ${ }^{717}$ require the intervenor to file one copy of its documents rather than the twenty or twenty-five now required. ${ }^{718}$ In Firestone, SOUP requested that the Commission pay travel expenses, living expenses, and per diem fees for its witnesses. The Commission declined to rule on the request, pending a determination by the Comptroller General on its statutory authority to make such payments. Chairman Kirkpatrick requested a ruling from the Comptroller General on the matter ${ }^{719}$ At this writing, no ruling has yet been made. Commissioner Jones has suggested that these expenses be considered necessary to the conduct of the Commission's proceedings, ${ }^{720}$ as are expenses of complaint counsel and Commission witnesses. ${ }^{721}$

\section{Federal Agencies Regulating Power Generation}

Federal regulation of the generation of energy, primarily electricity, is an extremely complex and highly technical matter. The problems that arise stem from both the nature of the subject matter and the multiplicity of regulatory bodies at various governmental levels charged with responsibility for different, or even identical, subject-matter regulation. Depending upon the energy source used, the generation of electric power may be federally regulated, in some aspects, by two agencies, the Federal Power Commission and the Atomic Energy Commission. The regulatory schemes of both agencies in this area are premised on congressional grants of licensing power over the construction and operation of generating facilities, ${ }^{722}$ each agency having responsibility for implementing a broad but not unlimited set of federal policies. ${ }^{723}$

Public participation in the decisionmaking procedures of the two agencies has developed independently of their common concern with

715 See notes 285-88 supra \& accompanying text.

716 Brief for Petitioner at 14, SOUP, Inc. v. FTC, No. 24,476 (D.C. Cir., filed July 24,1970 ).

717 Firestone Tire \& Rubber Co., 3 Trade Reg. Rep. If 19,519 (FTC 1971).

718 See 16 C.F.R. \$ 4.2(c) (1971).

719 Letter from FTC Chairman Kirkpatrick to Comptroller General Staats, Mar. 17, 1971, copy on file in Biddle Law Library, Univ. of Pa. Law School.

720 See 15 U.S.C. $\$ 42$ (1970).

721 Letter from FTC Commissioner Mary Gardiner Jones to Comptroller General Staats, Mar. 17, 1971, copy on file in Biddle Law Library, Univ. of Pa. Law School. Cf. Lazarus \& Onek, supra note 19 , at 1100.

722 See, e.g., 16 U.S.C. $\$ 797$ (e) (1970); 42 U.S.C. $\$ 2133$ (a) (1970).

723 See, e.g., 16 U.S.C. § 797 (c) (1970); 42 U.S.C. \$2013 (1970). 
the regulation of power generation. The following discussion treats each agency separately for this reason. At the same time, however, each discussion will emphasize the licensing of power generating facilities, and these discussions will be followed by a joint discussion focusing on this subject. Two reasons support this approach. First, public concern has singled out this activity of the agencies in recent years, and thus provides sufficient data to suggest problems and trends within the agencies. Second, most recent criticism of such regulation has been directed at the multiplicity of regulatory agencies at the state and federal level charged with responsibility for licensing power plants, the complexity thus injected into the decisionmaking process, and the consequent difficulties presented to those wishing to participate in the agencies' planning and licensing decisions. Recent proposals for improving the decisionmaking process would merge the agencies involved, instituting a consolidated system of licensing under federal authority (one-stop licensing) and formal long-range planning. ${ }^{724}$ Such proposals carry broad implications for the future role of public participation, and therefore warrant separate treatment.

\section{Federal Power Commission}

Certificates authorizing the construction and operation of hydroelectric facilities are granted by the Federal Power Commission for periods of up to fifty years. ${ }^{725}$ As of this time none of the certificates granted by the FPC has expired. ${ }^{\mathbf{7 2}}$ Consequently, and in contrast to the FCC's emphasis on frequent review of broadcasters' licenses to use the public airways, ${ }^{727}$ challenges by members of the public to the way in which certified facilities have been operated have been narrowly limited, occurring only in carefully circumscribed ratemaking proceedings. ${ }^{728}$

724 See text accompanying notes 918-21, 926-30 infra.

72516 U.S.C. $\$ 799$ (1970).

726 Interview with James Michael, Center for the Study of Responsive Law, Washington, D.C., in Washington, D.C., Sept. 27, 1971.

727 See text accompanying notes 325,337 supra.

$728 \mathrm{~A}$ recent instance of public interest intervention before the FPC occurred in Gulf Oil Corp., No. CI64-26 (FPC 1972), a proceeding to amend a certificate of public convenience and necessity granted Gulf for the sale of 4.4 trillion cubic feet of gas to Texas Eastern Transmission Corporation under a warranty contract. SOUP, the Washington Urban Ieague, Inc., and 50 utilities were granted intervention under $\$ 15$ (a) of the Natural Gas Act, 15 U.S.C. $\$ 717 n$ (1970). Countering the position taken by all but one of the intervening utilities, they argued that, if granted, the amendment would "ultimately cost the consuming public in excess of $\$ 160$ million" and that Gulf should therefore be held to its original contract. Petitioners' Motion for Emergency Relief at 5, SOUP, Inc. v. FPC, No. 72-1103 (D.C. Cir., filed Feb. 4, 1972). The issue presented in the Motion for Emergency Relief was "[t]o what extent does the public interest require the Commission to immediately provide intervenors, recognized [by the Commission] as responsible representatives of the public interest, the loan of a copy of the daily transcript [see 18 C.F.R. $\$ 1.21$ (a) (1971)] and relief from burdensome service requirements imposed by the Commission's Rules [see 18 C.F.R. $\$ \S 1.15(\mathrm{~b}), .17$ (b), .26(c), .29(e) (1971)], irrespective of intervenors' indigent status?" Id. SOUP and the Urban League argued that they were "not 
Initial certification of new facilities has been a more active area. As will appear below, the FPC has been liberal in admitting members of the public to such hearings so long as they wish to address matters the agency considers its responsibility. But when efforts have been made to invoke judicial review, and subsequently to force the agency to broaden its vision to encompass previously unexplored consequences of its certification, resistance has been frequent.

Despite the FPC's apparent acquiescence to participation at the hearing stage, few members of the public have exercised the opportunity, and the number is smaller yet if participation by competitors who have a substantial economic stake in the outcome is excluded. Traceable to the high cost of presenting an effective case in proceedings which are inherently complex and extraordinarily long, this pattern has a number of potentially unsatisfactory consequences. The agency attempts to limit the number of factors it must take into account in working out the "public interest." Those participants able to afford participation and then gain attention for issues otherwise avoided by the agency are extremely few. Because of this, the agency may often fail to consider the full range of issues relevant to the public interest. But even where it does consider these issues, the agency's perspective may be confined to the narrow interests of the rare intervenor. Fuller consideration is not necessarily better consideration, when the potential for limited or skewed perspectives is so great. Moreover, the effectiveness of judicial review as a prod on agency action is also reduced, when there is only infrequent intervention by narrowly interested groups.

The Federal Power Act (FPA) ${ }^{729}$ and the Natural Gas Act (NGA) ${ }^{730}$ are the basic sources for the regulatory authority of the Federal Power Commission. ${ }^{731}$ The FPC's jurisdictional responsibility under each has been expanded judicially over the years and is formulated somewhat differently in each, as will be shown below. Rules governing participation in FPC proceedings under these Acts are, however, identical in at least two respects. First, both statutes make participation discretionary with the Commission:

In any proceeding before it, the Commission, in accordance with such rules and regulations as it may prescribe, may admit

attempting to proceed as paupers in the conventional sense, but rather that they should receive financial relief in line with their status as recognized public interest intervenors." Id. 9-10; cf. notes 709-12 supra \& accompanying text. The motion was denied on Mar. 9, 1972, and the hearing examiner has not yet reached a decision on the merits. Telephone interview with Stuart Bluestone, Institute for Public Interest Representation, Washington, D.C., May 30, 1972.

72916 U.S.C. $\$ \$ 791 \mathrm{a}-825 \mathrm{r}$ (1970).

73015 U.S.C. $\$ \$ 717-717 \mathrm{w}(1970)$.

731 "The Federal Power Commission has certain specified duties under other statutes, but most of the Commission's time and other resources are consumed in the administration of the two basic Acts." Responses, supra note 30, at 89 . For an exhaustive compilation of other statutes defining the powers and duties of the FPC, see FPC, FEDERAL POWER ACT 61-156 (1970). 
as a party any interested State, State commission, municipality, or any representative of interested consumers or security holders, or any competitor of a party to such proceeding, or any other person whose participation . . . may be in the public interest. ${ }^{732}$

Second, in furtherance of a policy of close cooperation with state regulatory commissions, ${ }^{733}$ the Commission has promulgated rules which give any interested state commission an absolute right to intervene in any proceeding ${ }^{734}$ relegating all other intervenors to the status of petitioners for the opportunity to intervene. ${ }^{735}$

\section{a. The Natural Gas Act}

Under the NGA the Commission is empowered to regulate natural gas companies engaged in interstate transportation, or sale for resale, of natural gas. ${ }^{736}$ This power is exercised by certification of new facilities, regulation of producer and pipeline rates, and regulation of accounts, records, and securities. ${ }^{737}$ Applicants for proposed facilities must be granted construction certificates by the FPC, if it finds them "required by the present or future public convenience and necessity," 738 but "such reasonable terms and conditions as the public convenience and necessity may require" may be imposed. ${ }^{739}$ Before the grant of such a certificate, notice "to all interested parties" and a hearing are mandatory, ${ }^{740}$ even though participation in that hearing is said in the statute to be discretionary. ${ }^{741}$

Certification proceedings under the NGA have not been major battlegrounds. As has been observed:

Principal reasons for [the lack of controversy in NGA certifications compared to FPA certifications discussed below] include the fact that a great number of the major natural gas pipeline facilities were constructed throughout the United States under the spur and necessity of war-time needs or postwar-time recovery conditions. Secondly, during both periods, public need for gas utility facility development was not questioned. Third, the emergence of environmental pro-

73216 U.S.C. $\$ 825 \mathrm{~g}(\mathrm{a})$ (1970) ; accord, 15 U.S.C. $\$ 717 \mathrm{n}(\mathrm{a})$ (1970).

73318 C.F.R. $\$ 1.37$ (a) (1971).

734 Id. $\$ 1.37(\mathrm{f})$; see id. $\$ 1.8(\mathrm{a})(1)$.

$735 I d$. $\$ 1.8(\mathrm{a})(2)$.

73615 U.S.C. $\$ 717$ (b) (1970).

737 Id. $\$ \$ 717 \mathrm{c}, \mathrm{f}, \mathrm{g}, \mathrm{k}$.

738 Id. $\S 717 \mathrm{f}(\mathrm{e})$.

$739 I d$.

740 Id. $\$ 717 f(c)$.

${ }^{741} I d . \$ 717 \mathrm{n}$. 
tection as a great goal of our society is of relatively recent origin. ${ }^{72}$

The pressure on the FPC to admit nongovernmental participants during the periods of greatest construction came from producers of competing fuels and the litigation surrounding those efforts to intervene constituted an important chapter in the judiciary's expansion of the role of the public participant. ${ }^{743}$ The FPC consistently denied that the NGA's mandate to regulate to further the "public convenience and necessity" required the agency to consider the impact of its regulation of natural gas facilities on competing fuel industries. The reasoning, generally sustained by the courts, was succinctly stated in Alston Coal Co. v. FPC, ${ }^{744}$ a ratemaking proceeding:

$[T]$ he purpose of those provisions . . . relating to rates and prices . . . [was] to protect the consuming public against exorbitant and excessive charges .... [T] Commission must . . . fix a rate which will yield a fair return . . . The effect of a gas rate upon a competing industry fuel is not a factor which . . . the Commission may consider . . . . It follows that petitioners did not have the right . . . to intervene for the purpose of establishing the economic effect a reduction in gas rates would have upon the coal industry. ${ }^{745}$

This was not, of course, the end of the matter. In National Coal Association v. FPC, ${ }^{746}$ the court decided that it was appropriate to allow competitors judicial review of NGA certification. Apparently taking a somewhat different view of congressional intent than was expressed in Alston Coal, the court decided that all persons who would have a recognized right to obtain judicial review of a Commission order should be allowed to participate initially in the certification hearings.

[T] here are some persons who have a right to participate in Commission proceedings and some who do not. We think it clear that any person who would be "aggrieved" by the Commission's order, such as a competitor, is also a person who has a right to intervene. Otherwise, judicial review, which may be had only by a party to the proceedings before the Commission who has been "aggrieved" by its order, could be denied or unduly forestalled by the Commission merely by denying intervention. ${ }^{747}$

742 Nassikas, Public Participation in Locating Facilities, 88 PUв. UTIL. Forr., Sept. 16, 1971, at 108, 109.

743 See text accompanying notes 33-120 supra.

744137 F.2d 740 (10th Cir. 1943).

745 Id. at 741-42.

746191 F.2d 462 (D.C. Cir. 1951).

747 Id. at 467. See 15 U.S.C. \$717r(b) (1970); Juarez Gas Co. v. FPC, 375 F.2d 595 (D.C. Cir. 1967). See also Virginia Petroleum Jobbers Ass'n v. FPC, 265 F.2d 364, 368 (D.C. Cir. 1959); Mississippi River Transmission Corp., 39 F.P.C. 486 (1968); Consolidated Gas Supply Corp., 39 F.P.C. 38 (1968). 
With some practical justification, ${ }^{748}$ a distinction between certification and ratemaking proceedings has been retained. Because both the judicial review and hearing participation provisions in the NGA apply to all proceedings under that Act, ${ }^{749}$ there seems no firmer ground upon which to place the distinction than assumptions or conclusions concerning congressional intent. As a consequence of the distinction, the history of public participation under the National Gas Act remains of interest primarily for the judicially developed theory of intervention as of right rather than for its practical consequences within the FPC.

Public participation in fact has been allowed fairly freely. Using its statutory grant of discretion to allow intervention, the FPC, with judicial approval, has allowed coal companies to intervene in ratemaking proceedings. ${ }^{750}$ Furthermore, competitors have found the door almost completely open to intervention in ratemaking proceedings, despite the supposed principle of intervention by competitors only to serve the public interest. ${ }^{751}$ Finally, the FPC has several industry advisory committees, ${ }^{752}$ which "perform some valuable services in keeping the Commission informed about many developments and in making useful suggestions on policy matters." 753

Nevertheless, National Coal presents a significant lesson. The FPC had not in fact denied intervention to the competitor in National Coal, but instead had asserted its power to deny intervention as one ground supporting a denial of judicial review. ${ }^{754} \mathrm{~A}$ possible inference is that the agency was more concerned about the scope of the issues to be considered than about the burden of the additional participant. This suggestion finds support in the reviewing court's abrupt affirmance after reciting as the FPC's "substantial evidence," only evidence going affirmatively to the appropriateness of natural gas as a fuel. ${ }^{755}$ The conclusion suggested is that additional parties were not felt objection. able, but independent inquiry into the economic conditions of the coal industry was.

748 Professor Jaffe suggests that "[i]n terms simply of injury it is hard to explain a difference in standing of coal interests to contest a decision to certify new gas and one to price it so as to increase competition. But in terms of effect on the administrative process the distinction is valid. The initial decision to certify new gas is taken once and for all and is nearly irreversible. Rates can be changed; they should be flexible and the ratemaking process not too cumbersome." Jaffe, Standing to Secure Judicial Review: Private Actions, 75 HARv. L. Rev. 255, 276 n.71 (1961).

74915 U.S.C. $\$ \$ 717 b(c), r(b)$ (1970).

750 See Atlantic Seaboard Corp., 35 F.P.C. 158, 159 (1966) ; cf. 15 U.S.C. $\$ 717 \mathrm{r}$ (1970); 18 C.F.R. $\S 1.8$ (b) (3) (1971).

751 Fuels Research Council, Inc. v. FPC, 374 F.2d 842, 853 (7th Cir. 1967). See also United Fuel Gas Co., 28 F.P.C. 30 (1962); Northern Natural Gas Co., 23 F.P.C. 708 (1960).

752 Responses, supra note 30 , at 92 .

753 Id. at 86 .

754 See 191 F.2d at $466-67$.

755 Id. at 467. 


\section{b. The Federal Power Act}

Under the FPA the Commission is empowered to regulate supplies of electric power by licensing non-federal hydroelectric power projects, regulating interstate transmission and wholesale rates of electrical energy, and regulating the securities and accounts, and the mergers, consolidations, and acquisitions, of companies subject to its jurisdiction. ${ }^{756}$ The Commission is not required to license any project, but in those cases in which it chooses to grant licenses its responsibility is not framed in the traditionally expansive term "public interest." Instead licenses are to be issued in accordance with an elaborate list of "conditions," 757 including one to the effect that the project

shall be such as in the judgment of the Commission will be best adapted to a comprehensive plan for improving or developing a waterway or waterways for the use or benefit of interstate or foreign commerce, for the improvement and utilization of water-power development, and for other beneficial public uses, including recreational purposes . . . . ${ }^{758}$

A general provision adds that the Commission may impose conditions other than those listed in the statute if it wishes, ${ }^{759}$ presumably only so long as they serve some purpose implicit within the Act.

The FPA does not specifically require a hearing before the grant or denial of a license. ${ }^{760}$ The Ninth Circuit, however, has held that section 308 of the Act ${ }^{761}$ implicitly requires a hearing prior to the granting of a license. ${ }^{762}$ Under this construction the procedures of the Administrative Procedure Act are automatically incorporated. ${ }^{763}$ Whether acknowledging this as a proper construction of the FPA or independently determining that, for reasons of its own, a hearing is appropriate, the FPC has apparently adopted the practice of holding a

75616 U.S.C. \$797 (1970).

757 Id. $\S 803$.

$758 I d . \S 803$ (a).

759 Id. $\$ 803(\mathrm{~g})$.

760 Hearing procedures for proceedings under the FPA are specified generally in $i d . \$ 825 \mathrm{~g}$, which provides only that " $[\mathrm{h}]$ earings under this chapter may be held ... ." Power to issue licenses is conferred on the Commission by $i d$. $\$ 797(\mathrm{e})$, which requires general notice by publication and specific notice to "any state or municipality likely to be interested," $i d . \S 797(\mathrm{f})$, but no hearing pursuant to that notice. Neither the provisions for preliminary permits, id. $\$ \$ 797(f), 798,800$, nor the provisions conditioning licenses, $i d$. $\$ \$ 799,801-03$, add such a requirement as a condition to the grant of a license.

In contrast, remedial action for violation of conditions imposed in a license, including revocation, may only be effectuated pursuant to a federal district court judgment. Id. $\$ 820$.

761 IG UIS.C. $\$ 825 \mathrm{~g}$ (1970).

762 Public Ut11. Dist. Nio. 1 v. FPC, 242 F.2d 672, 678 (9th Cir. 1957). The court declared that: "Under $\$ 308$. . . the order granting the license was a matter 'required by statute to be determined - after opportunity for an agency hearing' within the meaning of $\$ 1004$ of Title 5 U.S.C.A."

763 See 5 U.S.C. \$554 (1970). 
hearing if a protest is filed to the proposed grant of a license. ${ }^{764}$ The former explanation is unlikely, for if a requirement of a hearing on a record can be inferred from the nature of the license provided for in the FPA, there is no justification for making the hearing conditional. In any event, since the Commission has promulgated no rules or orders either limiting the class of persons who may protest or requiring that protests meet any objective criteria, ${ }^{765}$ it appears that hearings are usually held before the grant of a license, and intervention is freely allowed.

Participation in such hearings is discretionary with the agency, ${ }^{766}$ but, as under the certification provisions of the NGA, the opportunity to participate apparently has not often been withheld. That the FPC has liberally allowed participation may fairly be inferred from the absence of detailed CAB-like rules governing the form of participation.

Yet, as noted at the beginning of this section, meaningful citizen participation before the agency has been "sorely lacking." 767 Furthermore, interested environmentalists and consumers have met resistance that has caused them to go to the courts for help in forcing the FPC to broaden its concept of its responsibility. Scenic Hudson Preservation Conference v. FPC ${ }^{768}$ is the leading case on the standing of conservationists to protect aesthetic and environmental interests by obtaining judicial review ${ }^{769}$ forcing the FPC to broaden the subject matter under consideration in its licensing hearings. The Second Circuit found that the Conference- "an unincorporated association consisting of a number of non-profit, conservationist organizations" 770 seeking to present relevant data in opposition to the proposed construction of a hydroelectric plant-had standing in court as a "party . . . aggrieved by an order issued by the Commission." 771 Although the Conference had "sufficient economic interest to establish [its] standing," ${ }^{772}$ the court added that the FPA "seeks to protect non-economic as well as economic interests," 773 and granted standing to the petitioners on the basis of their non-economic interests.

In order to insure that the Federal Power Commission will adequately protect the public interest in the aesthetic, con-

764 See 18 C.F.R. $\$ \$ 1.10,4.32$ (1970).

765 See id.

76616 U.S.C. $\$ 825 \mathrm{~g}(\mathrm{a})$ (1970).

767 See RESPONSES, supra note 30, at 85; accord, Hearings on S. 3434 \& S. 2544 Before the Subcomm. on Administrative Practice \& Procedure of the Senate Comm. on the Judiciary, 91st Cong., 2d Sess. 82 (1970).

768354 F.2d 608 (2d Cir. 1965), cert. denied, 384 U.S. 941 (1966).

769 See K. Davis, supra note $23, \S 22.19$ (Supp. 1970).

770354 F.2d at 611.

771 Id. at $615-16$ (citing 16 U.S.C. $\$ 825 l(b)$ (1970)). Scenic Hudson was initiated under the FPA. The parallel provisions under the NGA are found at 15 U.S.C. $\$ 717 \mathrm{r}$ (1970), which was the basis for National Coal. See note 747 supra. 772354 F.2d at 616.

773 Id. at 615 . 
servational, and recreational aspects of power development, those who by their activities and conduct have exhibited a special interest in such areas, must be held to be included in the class of "aggrieved" parties . . . . We hold that the Federal Power Act gives petitioners a legal right to protect their special interests. ${ }^{74}$

The FPA requires that as a condition for a license, a "project . . . shall be such as . . . will be best adapted to a comprehensive plan for improving or developing a waterway or waterways for . . . beneficial public uses, including recreational purposes . . ." 775 The court thought that the statute "encompasses the conservation of natural resources, the maintenance of natural beauty, and the preservation of historic sites," ${ }^{776}$ and remanded the case with instructions that the FPC admit and consider the evidence that the petitioners sought to offer. ${ }^{777}$

The court's logic on the standing issue has been criticized for being "filled with courageous leaps over intellectual chasms that might never be bridged" 778 and for "fail[ing] to connect the injury allegedly suffered . . . with the proposed relief." 779 Despite its technical shortcomings, however, the decision clearly shows the court's increasing willingness to supervise the FPC and dictate the breadth of its responsibility. ${ }^{780}$ Apparently Scenic Hudson considerably expanded the subject matter which the FPC must consider before granting a license. But it should be noted that when the case reached the court of appeals for the second time, FPC consideration of the impact of its licensing decision was approved on a record that showed a rather limited consideration of the effect the project would have on the environment and of the

774 Id. at 616 .

77516 U.S.C. $\$ 803$ (a) (1970).

776354 F.2d at 614.

777 Id. at 624. Such consideration was subsequently mandated by the Supreme Court in Udall v. FPC, 387 U.S. 428 (1967) (the Figh Monntain Sheep case).

The test is whether the project will be in the public interest. And that determination can be made only after an exploration of all issues relevant to the "public interest," including future power demand and supply, alternate sources of power, the public interest in preserving reaches of wild rivers and wilderness areas, the preservation of anadromous fish for commercial and recreational purposes, and the protection of wildlife.

$I d$. at 450 . Under these decisions, the consideration of non-power interests and the development of a full record are mandatory, see Comment, $O f$ Birds, Bees, and the FPC, 77 YALE L.J. 117, 120 (1967), and the FPC has recognized this obligation, see 35 Fed. Reg. 18,958 (1970).

The Second Circuit finally upheld the granting of a license, finding that the Commission's action complied with the remand and was supported by substantial evidence. Scenic Hudson Preservation Conference v. FPC, 453 F.2d 463, 470 (2d Cir. 1971) (Scenic Hudson II).

778 K. Davis, supra note 23, \$22.19, at 775 (Supp. 1970).

779 Comment, Standing of Conservation Organizations to Challenge Federal Administrative Action in Federal Court, 12 B.C. IND. \& CoM. L. Rev. 637, 642 (1971). 780 Cf. Tarlock, Preservation of Scenic Rivers, 55 Ky. L.J. 745, 777 (1967). 
available alternatives to that installation. ${ }^{781}$ In fact, the issues examined appear to have been limited to the impact of the one project rather than a "comprehensive plan" as called for by the FPA, ${ }^{782}$ and to the impact that project would have on an environment limited by the distance from which the installation could be seen, as a scathing dissent pointed out. ${ }^{783}$ Although the public participants in the proceeding included only nearby townships and groups of people concerned with the preservation of the Hudson River, ${ }^{784}$ the impact of the license will undoubtedly extend well beyond that area.

\section{c. The Public Interest and the Power Commission}

If public participation is thus limited in impact, it seems appropriate to consider the ways in which, within the context of the present federal regulatory structure, the deficiencies may be remedied, and whether there is room for adaptation of public participation to provide those remedies.

The expense and technical complexity of litigating before the FPC is recognized by the Commission to be "a very practical obstacle to widespread citizen participation." 785 This obstacle was judicially noted in Scenic Hudson in responding to the FPC's fears of thousands seeking intervention and review: "Our experience with public actions confirms the view that the expense and vexation of legal proceedings is not lightly undertaken." ${ }^{786}$ By the time Scenic Hudson initially reached the Second Circuit, the Conference had expended $\$ 250,000$, with the hearing on remand still awaiting. ${ }^{787}$ Few environmental or consumer groups possess the resources or staff to present such technical evidence as possible alternative sources of electrical energy, the effects on a river's oxygen caused by projects, or the thermal effects on fish. ${ }^{788}$ Moreover, the difficulty of obtaining engineers or other qualified wit-

781453 F.2d 482-85 (Oakes, J., dissenting). Cf. Comment, supra note 777, at 121. For a comprehensive report on the FPC response to environmental concern, see 50 FPC ANN. ReP. 4-5 (1970); Bagge, The Federal Power Commission, 11 B.C. IND. \& CoM. L. Rev. 689, 719-20 (1970). See also Responses, supra note 30, at 87.

782 See note 758 supra \& accompanying text. The court appears to have attached no significance to the fact that the project was not geared to "improving or developing a waterway," as 16 U.S.C. $\$ 803$ (a) (1970) requires. See 453 F.2d at 467.

783 See 453 F.2d at 492 (Oakes, J., dissenting).

784 The parties and intervenors are listed at 453 F.2d at $464-65 ; 354$ F.2d at 610 .

785 Responses, supra note 30 , at 86.

786354 F.2d at 617.

787 Comment, supra note 777 , at 120.

788 Kitzmiller, Environnental Preservation: Organizing and Protecting Consumer and Conservation Issues in an Administrative Proceeding, in ProceEDINGs of the Federal Hearing Examiners' Seventh Annual Seminar 34, 50 (1969).

The Sierra Club, however, may be able to make an adequate evidentiary showing, as it has nearly 100,000 members, a budget of $\$ 3,000,000$, and a 60 -man staff with 20 volunteer attorneys. See Sierra Chub Mounts a New Crusade, Busrness WeEk. May 23, 1970, at 64-65. 
nesses to testify is exacerbated by the fact that most of the experts on those matters have allegiance to power companies. ${ }^{789}$

The Commission has recently considered the extent to which participants in FPC proceedings may receive public financial support. In 1970, People Organized to Win Effective Regulation (POWER) was allowed to intervene in rate increase hearings but the Commission

den[ied] the request by POWER that it be allowed an initial $\$ 10,000$ in costs and fees payable by the Commission to act as public interest and consumer surrogate in lieu of the Commission. Although the participation of POWER and all other parties is encouraged in this proceeding, the Commission has not and will not abdicate its mandate to represent the public interest. Therefore, a volunteer surrogate will not be appointed in lieu of the Commission. ${ }^{790}$

The Commission did, however, allow intervening parties leave to proceed in forma pauperis in order to receive a transcript without charge or to be relieved of filing copies of written submissions and of serving copies upon other parties. ${ }^{791}$

The Commission and the public interest seem, however, to be in a state of equilibrium:

Increasingly, matters coming before the Commission involve complex issues of industrial technology, law, economics and finance. This acts as a very real limitation on effective participation by the individual citizen or private citizen groups unless they have substantial resources to employ the required expertise. On the other hand, our liberal policy of allowing all interested parties to intervene . . does bring into play powerful forces that represent the consumer and the general public, or whose interests are essentially the same. ${ }^{792}$

It has been suggested that "perhaps all we have to do is raise the [environmental] question to a responsive commission which, recognizing that it may face a court review, should then .. . of its own motion see that the question was properly answered." 793 The principle of intensive staff involvement in the planning and execution of service and facility proposals has been called regulatory "activism." 794 In appro-

789 See Kitzmiller, supra note 788, at 51.

790 Initial Rates for Future Sales of Natural Gas for All Areas, 44 F.P.C. 655, 657 (1970).

791 Id. at 659.

792 Responses, supra note 30 , at 110 .

793 Kitzmiller, supra note 788, at 36. But cf. Rocky Mountain Power Co. v. FPC, 409 F.2d 1122, 1129 n.29 (D.C. Cir. 1969).

794 Seder, Regulatory Activism-The Aftermath of Scenic Hudson, in ABA Pub. Util. L. Section AnN. Rep. 3, 8 (1969). 
priate cases, the FPC staff ${ }^{795}$ should move beyond the mere consideration of competing proposals to directing the parties to consider alternatives or even to preparing its own proposals, ${ }^{796}$ a practice which the staff has occasionally followed with limited success. Staff investigation could obviate much of the need for costly and time-consuming intervention, thereby removing a burden that citizen groups must otherwise shoulder. Staff initiative and intervention, however, may present due process/requisite notice problems. ${ }^{797}$ According to one authority, "If . . . the Commission favors an alternative not comprehended by the original public notice, due process would appear to require additional notice and opportunity for hearing." 798 Meeting such requirements might produce endless delay and repetitious proceedings. ${ }^{799}$

Whether the FPC staff or citizen groups should bear the responsibility of protecting the public's concern with the environment or whether public intervention should increase, are questions which can be expected to be asked with increasing frequency. The National Environmental Policy Act of 1969 (NEPA) ${ }^{\mathbf{8 0 0}}$ directs all federal agencies to "study, develop, and describe appropriate alternatives to recommended courses of action in any proposal which involves unresolved conflicts concerning alternative uses of available resources," 801 and to "initiate and utilize ecological information in the planning and development of resource-oriented projects." ${ }^{802}$ The FPC has adopted rules to implement the NEPA. ${ }^{803}$

Judicial and congressional requirements alone, irrespective of citizen intervention, can, of course, lead to added delay in the administrative process.

795 The Commissioners themselves rely very heavily on the expertise of the staff on specialized questions of law, engineering, economics, and accounting. See RESPONSES, stpra note 30 , at 111. Similarly, some intervenors rely on the FPC staff analysis of a proposed project. Telephone interview with William Arkin, Staff of FPC General Counsel, Aug. 17, 1971.

796 Seder, supra note 794 , at 17 . Notwithstanding the requirement that the FPC fully consider alternatives presented by parties to proceedings under Scenic Hudson, "the role of the agency in encouraging or directing the presentation of alternatives should be limited principally to situations in which a clearly-defined question of public policy presented by the application can best be resolved by formulating and presenting an alternative proposal." Id.

797 Id. 15.

798 Id.

799 See, e.g., Manufacturers Light \& Heat Co., 39 F.P.C. 294 (1968) ; Pacific Gas Transmission Co., 40 F.P.C. 1147 (1968); Great Lakes Transmission Co., 37 F.P.C. 1070 (1967).

The remand of the High Montain Sheep case, 387 U.S. 428 (1967), is perhaps the most sterling example of regulatory activism. The FPC staff, which had testified about power supply resources, see Initial \& Reply Brief of Commission Staff Counsel at 58, Pacific Northwest Power Co., Project No. 2243 (FPC, Feb. 23, 1971) (Presiding Examiner's Initial Decision on Remand), developed in its own cost estimates, id. 66-102, and asserted the same sentiment for environmental protection which would be expected from the conservation groups.

80042 U.S.C. $\$ \$ 4321$ et seq. (1970).

801 Id. $\$ 4332(\mathrm{D})$.

802 Id. $\$ 4332(\mathrm{G})$.

803 See 18 C.F.R $\$ 2.80-.82$ (1971). 
The question as to whether the agency's decision-making processes operate with reasonable speed is not a simple one. . . The problems arise when unique situations are presented or there are parties opposing one another. When a matter goes to full hearing, there are many opportunities for delay, either intentional or unintentional. Some delay is inherent and, indeed, essential to a full consideration of all relevant factors, particularly with the increased concern . . . on the part of the public . . . [with] the environment. In the past, the Commission has not given as much attention to environmental factors as it should have, with the result that our expertise is not fully developed. This can lead to delay when we have to grapple with unfamiliar areas of concern .... ${ }^{804}$

The "unprecedented concern and agitation for the environment" 805 has delayed the construction of new power facilities as the demand for power approaches the crisis stage. After nine years, ${ }^{806}$ the Scenic Hudson battle has finally been resolved ${ }^{807}$ and Consolidated Edison has made a number of concessions, ${ }^{808}$ and it is not at all clear whether the public interest will be served by further delay. ${ }^{809}$ Where the choice is one between air-conditioning in the summer and cheap power in the ghetto, as opposed to healthy fish swimming in crystalline streams, the value of intervention by environmentalists is not always clear. "[M] any of these groups may have their own interests to protect which, while protecting one group of citizens, may be adverse to another group." 810 For example, landowners, claiming that the public interest commands intervention, may intervene to delay proceedings in order "to force higher prices for rights of way." 811 The "flood of horribles" argument offered in opposition to increased participation has been consistently rejected, ${ }^{812}$ but agencies must be aware of what interests are being urged and what risks accompany them.

804 Responses, supra note 30 , at 87 (Statement of Chairman White).

805 Ramey \& Murray, Delays and Bottlenecks in the Licensing Process Affecting Utilities: The Role of Improved Procedures and Advance Planning, 1970 DuKE L.J. $25,28$.

${ }^{806}$ Thimmesch, Lilliputian Ecologists Hogtie Utility Giants, Evening Bulletin (Philadelphia), Oct. 5, 1971, at 29, col. 1. Intervenor expenses have now risen above the half-million dollar mark. Id. col. 3 .

807 See Scenic Hudson Preservation Conference v. FPC, 453 F.2d 463 (2d

Cir. 1971).

808 Id. at 466.

809 The controversial Blue Ridge hydroelectric project is presently being challenged by environmental groups and political units and promises to be a protracted proceeding. See N.Y. Times, Nov. 12, 1971, at 18, col. 1 .

810 Responses, supra note 30 , at 85 .

811 Id. 87.

812 See, e.g., Scenic Hudson Preservation Conference v. FPC, 354 F.2d at 617:

We see no justification for the Commission's fear that our determination will encourage "literally thousands" to intervene and seek review in future proceedings. 
In 1960, Dean Landis castigated the FPC as representing "the outstanding example in the federal government of the breakdown of the administrative process." 813 This statement was largely provoked by the enormous backlog of cases before the FPC, including several thousand individual gas producer rate cases. ${ }^{814}$ By 1969, producer rate cases numbered six, due to the implementation of the procedure of setting area rates. ${ }^{815}$ The hearing process has also been simplified by use of prehearing conferences, filing of written rather than oral testimony, independent accounting certifications, and bifurcated hearings which encourage settlement after the first phase. ${ }^{816}$

From all indications, then, it appears that the FPC has been liberal in its intervention policy. Yet dissatisfaction with the results of the agency's work is widespread, and appears to come from members of the public not represented in the hearing process, experts in the field, and judges, with equal vigor. If a broader base of public participation is to be found, and the frequency of such participation increased, without a restructuring of the FPC or an enormous increase in the administrative burdens of the agency, perhaps the most appropriate solution is a decrease in formal participation and the expansion of the FPC advisory committees to include concerned citizen groups, a proposal urged by former FPC Chairman White. ${ }^{\text {S17 }}$ Alternatively, Commissioner Bagge has suggested the establishment of a formalized consultative process between government and business, joint planning, and increased reliance on rulemaking at the expense of adjudication..${ }^{818}$

\section{Atomic Energy Commission}

The Atomic Energy Commission is charged by the Atomic Energy Act ${ }^{819}$ with broad responsibility for the licensing and regulation of nonmilitary aspects of the development and application of atomic

Representation of common interests by an organization such as Scenic Hudson serves to limit the number of those who might otherwise apply for intervention and serves to expedite the administrative process.

Accord, Associated Indus., Inc. v. Ickes, 134 F.2d 694 (2d Cir.), vacated as moot, 320 U.S. 707 (1943).

813 Chairman of the Subcomm. on Administrative Practice \& Procedure of the Senate Comir. on the Judiciary, 86th Cong., 2D Sess., Report on Regulatory Agencies to the President-Elect 54 (Comm. Print 1960).

814 Bagge, siepra note 781, at 690 .

815 Id. See also Jaffe, The Federal Regulatory Agencies in Perspective: Administrative Limitations in a Political Setting, 11 B.C. IND. \& CoM. L. REv. 565, 569 (1970).

816 RESPONSES, supra note 30 , at 95.

817 Id. 86.

818 Bagge, Broadening the Supply Base-A Proposal to Eliminate Producer Price Regulation, 3 Nat. RES. LAW. 430, 432 (1970).

81942 U.S.C. $\S \S 2011-96$ (1970). 
energy. A nonexhaustive list of those activities that are licensed by the AEC includes the construction and operation of any facility producing or using nuclear material, and the possession, shipment, or disposal of such material. ${ }^{820}$ While intervenors have been active in other areas of AEC concern, ${ }^{821}$ the most significant proceedings in terms of public participation and volume of litigation are applications for licenses authorizing the construction of new nuclear power plants. ${ }^{822}$ Standards for issuance of such licenses are stated generally in the Act:

The Commission shall issue such licenses on a nonexclusive basis to persons applying therefor (1) whose proposed activities will serve a useful purpose proportionate to the quantities of special nuclear material or source material to be utilized; (2) who are equipped to observe and who agree to observe such safety standards to protect health and to minimize danger to life or property as the Commission may by rule establish; and (3) who agree to make available to the Commission such technical information and data concerning activities under such licenses as the Commission may determine necessary to promote the common defense and security and to protect the health and safety of the public. ${ }^{823}$

Additionally, all power-generating facilities licensed by the AEC are explicitly subjected by the Act to regulation by the Federal Power Commission under the Federal Power Act. ${ }^{824}$

\section{a. The Licensing Proceeding}

Section 185 of the Atomic Energy Act ${ }^{825}$ establishes a two-stage licensing process through which an applicant may secure the permission of the AEC to operate a nuclear power plant. The first stage involves the issuance of a provisional construction permit, which may be secured only after a mandatory public hearing. ${ }^{826}$ The issuance of an operating license, which comprises the second stage of the licensing procedure, may occur without another public hearing unless one is requested by

820 For a complete listing of AEC licensing responsibilities, see 42 U.S.C. $\S \S 2073,2139(1970)$.

821 See, e.g., City of New Britain v. AEC, 308 F.2d 648 (D.C. Cir. 1962) (municipality opposing licensing of trucking firm to receive, store, and dispose of radioactive waste).

822 An analysis of the role of public representatives in the AEC rulemaking process will not be extensively treated. In conformity with the Administrative Procedure Act, 5 U.S.C. $\$ \$ 553-54$ (1970), the AEC has provided for formal hearings in licensing cases and informal hearings, with public participation limited to written submissions and non-record interviews, in rulemaking proceedings. See Siegel v. AEC, 400 F.2d 778, 785-86 (D.C. Cir. 1968).

82342 U.S.C. $\$ 2133$ (b) (1970).

$824 I d . \$ 2019$.

$825 I d . \S 2235$.

826 See id. $\$ 2239(\mathrm{a})$. 
an interested person. ${ }^{827}$ The mandatory hearing requirement at the construction permit stage recognizes that the grant of permission to build is the most critical decision in the licensing process. ${ }^{828}$

Upon receipt, an application for a construction permit ${ }^{829}$ is evaluated by the AEC's Division of Reactor Licensing, which normally consults with the applicant to solve problems discovered in its review of the applicant's preliminary safety report. ${ }^{830}$ During the review of a construction permit application, the regulatory staff analyzes the safety features of the application and balances the risk of a major accident against the cost to the applicant and the benefit to society of having the utility. ${ }^{831}$ This process involves extended informal discussions and negotiations between the staff and the industry applicant, where "the staff may yield more than the public interest would allow." ${ }^{832}$ An independent review of the safety of the proposed project is required to be made by the Advisory Committee on Reactor Safeguards, ${ }^{833}$ and this report and the AEC staff's safety evaluation are then introduced as evidence at the mandatory hearing. ${ }^{834}$ At an uncontested hearing the Atomic Safety and Licensing Board does not consider the evidence de novo but determines whether the AEC staff review has been adequate to support the proposed findings. ${ }^{835}$ If an application is contested, either by the AEC regulatory staff or by an intervening party, then the board will make an independent determination of any matters in con-

827 Id.

${ }^{828}$ See H.R. Rep. No. 1966, 87th Cong., 2d Sess. 8 (1962) (emphasizing importance of the fact that site selection is finally determined at this stage of the process). See also Power Reactor Dev. Co. v. Union of Elec. Workers, 367 U.S. 396, 417 (1961) (dissenting opinion) (recognizing that the investment of millions of dollars subsequent to the grant of a construction permit would make decisions at that stage practically irreversible).

For a detailed discussion of the construction permit process, see Kingsley, The Licensing of Nuclear Power Reactors in the United States, 7 Atom. EN. L.J. 309 (1965). See also AEC, LICENSING of Power REACTORS (1967); Murphy, Atomic Safety and Licensing Boards: An Experiment in Administrative Decision Making on Safety Questions, 33 LAw \& CoNTEMr. PROB. 566 (1968); Note, The Regulation of Nuclear Power After the National Environmental Policy Act of 1969, 24 RuTGERS L. REv. 753, 755-58 (1970).

829 For the required contents of an application, see 10 C.F.R. $\$ \$ 50.33-.34$ (1972); id. $\$ 50$, Apps. B-E.

830 See Kingsley, sipra note 828 , at 319-20.

831 Ellis \& Johnston, Licensing of Nuclear Power Plants by the Atomic Energy Commission 7 (1971) (tent. staff report prepared for the Administrative Conference). 832 Cavers, Administering That Ounce of Prevention: New Drugs and Nuclear Reactors-II, 68 W. VA. L. REv. 238, 242 (1966); cf. REsponses, supra note 30, at 789 ("The AEC regulatory staff operates under the philosophy of making an independent assessment of the safety of a proposed nuclear facility or installation. Although this assessment requires much of the information to be provided by the regulated enterprises, independent calculations are made in appropriate areas . . . ."). 833 See 42 U.S.C. $\$ 2039$ (1970). The Advisory Committee on Reactor Safeguards consists of fifteen members of the scientific community, who are appointed by the Commission and serve on a part-time basis. See Kingsley, supra note 828, at 322-24.

834 See Kingsley, supra note 828 , at 326-28.

835 Green, Safety Determinations in Nuclear Power Licensing: A Critical Viere, 43 Notre Dane Law. 633, 642 (1968). 
troversy. "By the time the recommendations reach the board-and are first made public-the staff, ACRS, and the applicant have ironed out all of their differences. In a subsequent public hearing all three will present a united front against anyone seeking to challenge the results of their private deliberations." ${ }^{337}$ The "public hearings are mere window dressing," 838 with the "basic licensing decisions . . . made by technical specialists operating beyond effective public scrutiny." 839 This situation is compounded by the fact that "the reactor licensing program is presently conducted with some degree of bias in the direction of technological advance." 840 It becomes clear that "once a construction permit proceeding emerges into the public arena with the imprimatur of the ACRS and the AEC regulatory staff affixed to the license application, the presumption is that the permit will be issued, and all official efforts are exerted in behalf of issuance of the permit." ${ }^{841}$ Any member of the public challenging issuance must bear a heavy burden of proof. ${ }^{842}$

\section{b. Intervention Before the $A E C$}

The Commission's intervention rules state:

(a) Any person whose interest may be affected by a proceeding and who desires to participate as a party shall file a written petition ... to intervene. . . The petition shall set forth the interest of the petitioner in the proceeding, how that interest may be affected by Commission action, and the contentions of the petitioner in reasonably specific detail. A petition which sets forth contentions relating only to matters outside the jurisdiction of the Commission will be denied.

(d) An order permitting intervention may be conditioned on such terms as the Commission or presiding officer may direct.

836 See AEC, LICENSINg of Power ReActors 9 (1967).

837 Ellis \& Johnston, supra note 831, at 15.

838 Green, supra note 835 , at 652 .

839 Id. 653.

840 Id. 649. Dr. Glenn T. Seaborg, former chairman of the AEC, however, has stated that the licensing and regulatory branches of the AEC "were relatively free of the influence of these branches that promote the use of atomic energy." N.Y. Times, Sept. 16, 1971, at 14, col. 1 .

841 Green, supra note 835, at 655. Cf. Ellis \& Johnston, supra note 831, at 42.

842 It has been suggested that the burden of proof at the hearing be inverted and that the AEC staff counsel "adopt the posture of representing the interest of the public health and safety. Rather than exerting his efforts on behalf of the applicant as is now done, he could very easily put the applicant to its proof . . ."Green, supra note 835 , at 656 . Dr. James $R$. Schlesinger, present AEC chairman, by redefining the agency's role as that of performing "as a referee serving the public interest," has indicated that the AEC is moving in this direction. See N.Y. Times, Oct. 21,1971 , at 23 , col. 4 . 
... The granting of a petition to intervene does not change or enlarge the issues specified in a notice of hearing unless otherwise expressly provided in the order allowing intervention. ${ }^{843}$

Pursuant to these rules, the AEC has consistently espoused a liberal policy in favor of granting intervention to interested members of the public, ${ }^{844}$ including labor unions, ${ }^{845}$ state and local governments, ${ }^{846}$ and conservation groups. ${ }^{847}$

The present rigidity in $\mathrm{AEC}$ intervention procedures partially explains the Commission's apparent willingness to grant intervention to representatives of the public. The Atomic Energy Act commands that "the Commission shall grant a hearing upon the request of any person whose interest may be affected by the proceeding, and shall admit any such person as a party to such proceeding." 848 This provision has been interpreted to leave some room for administrative discretion to deny participation to persons whose interests are already adequately represented by other parties. ${ }^{849}$ The Commission, however, has failed to formulate any rule of procedure to deal with the problem of persons seeking to intervene for the purpose of raising the same issues, ${ }^{850}$ thereby inhibiting board exercise of its discretionary power to deny intervention.

The rules governing the status of nonintervening participants in construction permit hearings further inhibit the exercise of discretion in the consideration of petitions to intervene.

84310 C.F.R. $\$ \S 2.714(\mathrm{a})$, (d) (1972).

844 See, e.g., Ramey, The Role of the Public in the Developnent and Regulation of Nuclear Power, 12 ATom. EN. L.J. 3, 17 (1970) (remarks of AEC Commissioner Ramey at the Conference on Nuclear Energy and the Environment, Apr. 4, 1970); Hennessey, Atomic Energy Laz-A Look Into the Future, 12 Atom. EN. L.J. 235, 247 (1970) (address by AEC General Counsel Hennessey to the AII-ABA Joint Committee on Continuing Legal Education Course of Study on Atomic Energy Licensing and Regulation, Sept. 10, 1970).

845 See, e.g., Power Reactor Dev. Co., 1 A.E.C. 1 (1956), aff'd, 367 U.S. 396 (1961), rev'g 280 F.2d 645 (D.C. Cir. 1960).

846 See, e.g., Consumers Power Co., 1 A.E.C. 300 (1960); Department of Water \& Power, 3 A.E.C. 1 (1965).

${ }^{847}$ See, e.g., Department of Water \& Power (Malibu Nuclear Plant Unit No. 1), 3 A.E.C. 122 (1966) (board granted intervention to the Malibu Citizens for Conservation, Inc., in construction permit proceeding).

84842 U.S.C. \$2239(a) (1970) (emphasis added). See also REsponses, supra note 30 , at 779 . One commentator has observed that a statutory provision which gives any interested person a right to be a party is undesirable, insofar as it may tend to limit the discretion of agencies to control the hearing process by denying intervention to those persons whose interests are adequately represented by existing parties. See Shapiro, supra note 37, at 766-67.

${ }^{849}$ See Cities of Statesville v. AEC, 441 F.2d 962, 977 (D.C. Cir. 1969).

850 The Civil Aeronautics Board has promulgated seven criteria to guide the hearing examiner in his determination whether or not to permit formal intervention. See 14 C.F.R. \$ 302.15 (b) (1971) \& note 514 supra. See also 18 C.F.R. \$1.8(b) (2) (1971) (Federal Power Commission regulation indicating that intervention need not be granted if petitioner's interest is adequately represented by existing parties). 
A person who is not a party may . . . be permitted to make a limited appearance by making oral or written statement of his position on the issues within such limits and on such conditions as may be fixed by the presiding officer, but he may not otherwise participate in the proceeding. ${ }^{851}$

The above "limited appearance provision" does not bestow the limited participant with a full panoply of litigation rights and would not appear to satisfy the statutory command that interested persons affected by a proceeding be accorded the rights of a party. ${ }^{852}$ As a result, the board knows that if it denies intervention on the grounds that a person's interests are adequately represented and relegates such person to a limited appearance status, the proceeding may be subject to successful challenge on review if it turns out that their interests were not so represented at the hearing. Thus, under the present rules, the failure of the limited appearance provision to allow enough flexibility to permit nonparties the privilege of cross-examination, discovery, ${ }^{853}$ and the opportunity to avail themselves of the appellate review procedure ${ }^{854}$ dictates that intervention be granted in order to minimize the risk of reversal. ${ }^{855}$ The procedural rules regarding limited appearances should be changed to permit limited participants the right of cross-examination and other procedural rights, when it becomes apparent during the course of the hearing that the person's interests are not in fact adequately represented..$^{856}$ Combined with more selective granting of intervention, this would provide a means for greater control over the hearing process, while satisfy-

85110 C.F.R. $\$ 2.715$ (a) (1972).

852 See 42 U.S.C. $\$ 2239$ (a) (1970) ; Responses, supra note 30 , at 780 ("The Commission encourages members of the general public to state their position or to raise any questions they wish, within the scope of the issue of the proceeding and AEC jurisdiction. However, such persons do not become parties and their statements or presentations are not part of the record for decision.").

${ }^{853}$ The Commission may, "on motion of any party showing good cause and on notice to all other parties," order discovery. 10 C.F.R. $\$ 2.741$ (1972). Only intervenors can get discovery, and petitions for leave to intervene are not acted upon until notice of the mandatory hearing is issued. This would appear to be an extremely short time for an intervenor to fully prepare his case. "Because of the timing of an intervention in AEC hearings, the largest problem intervenors face is getting information early enough to analyze issues." Letter from Myron M. Cherry, Businessmen for the Public Interest, to the University of Pennsylvania Law Review, Oct. 5, 1971, on file in Biddle Law Library, Univ. of Pa. Law School. It has been suggested, however, that "[i]f . . . petitioners are allowed to intervene and require time for discovery, the board may in its discretion adjust the date of the hearing as the circumstances may indicate." Department of Water \& Power, 2 A.E.C. 445 (1964). See also 10 C.F.R. \$2.744 (1972) (limited access to AEC records).

85410 C.F.R. \$2, App. A, IIT(b) (5) (1972).

855 Compare the AEC rule on limited appearances, supra note 851 , with the Civil Aeronautics Board's rule 14, which governs informal participation in CAB proceedings. See notes 524-25 supra \& accompanying text.

856 Cf. Palisades Citizens Ass'n v. CAB, 420 F.2d 188 (D.C. Cir. 1969) (CAB's denial of formal intervention to certain public interest groups held not to be error, where the groups were given the opportunity to present exhibits and to cross-examine witnesses pursuant to $\mathrm{CAB}$ rule 14 and to participate in oral argument before the examiner, a privilege not mentioned on the face of the rule). 
ing the statutory requirement that interested persons be given the status of parties.

The AEC has to some extent modified the rigidity of its intervention scheme by directing that representatives of interested states which are not parties be afforded "a reasonable opportunity to participate and to introduce evidence, interrogate witnesses, and advise the Commission" without being required to take a position with respect to the issues. ${ }^{857}$ In any future rule change, this special form of intervention might be extended to those experienced public interest groups who are perhaps better able than many government units to protect the public interest in defined controversial areas.

In addition to the constraints imposed by the intervention rules, the AEC's general lack of discrimination as to the type of person or group allowed to intervene may be attributed to the Commission's longstanding desire to draw the public into the hearing process. ${ }^{858}$ This may in large measure be explained by the fact that construction permit proceedings have been considered to function simply as a forum in which " $[\mathrm{m}]$ embers of the public . . . can intervene . . . and can call witnesses and cross-examine in order to try to satisfy themselves as to the safety of the proposed plant." 859 The primary purposes of the hearing-to convince the public that the AEC staff has diligently reviewed an application and to demonstrate that it is decidedly in the public interest ${ }^{860}$-are actually promoted by liberally providing a public forum.

As a result of the factors noted above, denials of petitions to intervene have been relatively few in number. In those cases where it has occurred, two frequently cited grounds for denial have been that the petition to intervene alleged issues relating only to matters outside the jurisdiction of the Commission or contained contentions that tended to change or enlarge the issues to be considered at the hearing. Such denials have included a case where the petitioner sought only to challenge the constitutionality of the Atomic Energy Act ${ }^{801}$ and instances where petitioners attempted to raise antitrust considerations at construction permit hearings. ${ }^{862}$

85710 C.F.R. $\$ 2.715$ (c) (1972).

858 Telephone interview with A. W. Murphy, Professor of Law at Columbia University and a member of the Atomic Safety and Licensing Board Panel, Aug. 16, 1971.

859 Ramey, supra note 844 , at 17 . See note 838 supra \& accompanying text.

800 Report to the Atomic Energy Commission by the Regulatory Review Panel (Mitchell Panel) (1965), in Hearings on Licensing \& Regulation of Nuclear Reactors Before the Joint Comm. on Atomic Energy, 90 th Cong., 1st Sess., pt. 1 App., at 415 (1967) ; Ellis \& Johnston, supra note 831, at 42; Green, supra note 835, at 639-40.

$801 \mathrm{See}$ Toledo Edison Co. \& Cleveland Elec. Illuminating Co. (Davis-Besse Nuclear Power Station), 2 CCH Árom. EN. L. REP. đ11,594.01, at 17,735-2 (1971). 862 See, e.g., Cities of Statesville v. AEC, 441 F.2d 962, 967 (D.C. Cir. 1969) (court granted intervention but refused to consider the antitrust issues).

The AEC must now pass on the anticompetitive effect of an application prior to issuing a construction permit. See 42 U.S.C. $\$ \$ 2132-35$ (1970); 10 C.F.R. $\$ \$ 50.41$ - 
Other grounds for denying intervention are that the petition failed to conform with the $A E C$ 's technical rules of practice ${ }^{863}$ or that the petition was not filed within the required time. ${ }^{864}$ The Commission's rules state that "[a] petition for leave to intervene which is not timely filed will be dismissed unless the petitioner shows good cause for failure to file it on time." ${ }^{865}$ In Easton Utilities Commission v. AEC, ${ }^{866}$ the court found the AEC's right to so limit intervention to reside in its statutory authority to "make, promulgate, issue, rescind, and amend such rules and regulations as may be necessary to carry out the purposes of [the Atomic Energy Act]." ${ }^{867}$ The court acknowledged that the orderly conduct of public business demands that there be agency discretion to deny an untimely application, notwithstanding the governing statutory language indicating that a person has an affirmative right to intervene based on the interest he presents. ${ }^{868}$

Another consideration in acting upon a petition to intervene is whether a petitioner's interests will in fact be affected by the proceeding. ${ }^{869}$ This determination must necessarily be made on a case-by-case basis and is not amenable to detailed rulemaking. In the Diablo Canyon construction permit hearing, ${ }^{870}$ a conservation group and an individual filed a joint petition to intervene. Both sought intervention to contest the ecological, health, and safety effects of a proposed nuclear power plant. The environmentalist group asserted that approximately ten of its members resided within ten to fifty miles of the proposed plant, and was allowed to intervene. A decision on the status of the single individual, who lived 112 miles from the site, was deferred pending an inquiry into the frequency of his visits to the plant area. The petitioner failed to reply to the inquiry and intervention was denied. This decision indicates that geographic proximity may be an element in the determination of whether a person's interest is affected to such an extent that intervention must be granted. ${ }^{871}$ On the other hand, the board

$.42, .55 \mathrm{~b}(1972)$. This opportunity to challenge an application will likely increase the number of interventions and further delay the application process. See Ellis \& Johnston, supra note 831, at 30-33.

803 See, e.g. Northern States Power Co. (Monticello Nuclear Generating Plant), 3 A.E.C. 216, 217 n.2 (1967) (local citizens group's petition to intervene denied for failure to "set forth the interest of the petitioner, how that interest would be affected by Commission action, and the contentions of petitioner").

864 See, e.g., Consolidated Edison Co. (Indian Point Station Unit No. 2), 3 A.E.C. 162 (1966).

86510 C.F.R. $\$ 2.714$ (a) (1971).

866424 F.2d 847 (D.C. Cir. 1970).

$867 I d$. at 851 (citing 42 U.S.C. $\$ 2201$ (p) (1964)).

$868 \mathrm{Id}$. at 852 .

860 See 42 U.S.C. $\$ 2239$ (a) (1970).

870 Pacific Gas \& Elec. Co. (Diablo Canyon Nuclear Power Plant), $2 \mathrm{CCH}$ Ator. EN. L. Rep. \11,270.01 (1968).

871 Cf. Petition to Intervene, Point Beach Nuclear Plant, Unit No. $2,2 \mathrm{CCH}$ Atom. EN. L. REp. I11,276 (1968), where the petitioners Businessmen for the Public Interest, Sierra Club, and Protect Our Wisconsin Environmental Resources (POWER), were careful to allege that some of their members were local residents and otherwise geographically proximate to the site of the plant. 
may have been persuaded that the particular interests which the individual petitioner sought to protect were already represented by a public interest group that was apparently better able to present a full case. Granting the individual's petition could have placed additional burdens on the hearing process without any assurance that the outcome would be seriously affected.

The need to determine whether a particular intervenor can contribute to a proceeding as a basis for deciding whether to permit intervention will become increasingly important as additional applications for construction permits are received ${ }^{872}$ and the average hearing time increases. ${ }^{873}$ Prior to the recent expansion of the Commission's jurisdiction over environmental and antitrust issues, ${ }^{874}$ relatively few persons or groups sought to intervene in construction permit proceedings. ${ }^{875}$ Only in the past few years have there been large numbers of attempted interventions. ${ }^{876}$ The legitimizing function of the mandatory hearing has also contributed to protracted proceedings.

The result of privacy at the prehearing "negotiation" stage and an air of partiality at the hearing stage has been the creation of an artificial and distrustful atmosphere for the licensing process. The interveners see the licensing hearing as stacked, and they tend to retreat to the tactic of delay rather than plotting a strategy for victory.

The problem is compounded by the advent of "public interest" groups which employ able counsel and participate fully as interveners. Substantial delays have occurred at the hearing stage in almost every case in which private citizens or

872 In mid-1971 there were 22 operating nuclear power plants, 55 additional plants under construction, and 45 planned or ordered. The AEC estimates that there will be 950 operating plants by the end of the century. See N.Y. Times, Feb. 17, 1971, at 41 , col. 6. Cf. Ellis \& Johnston, supra note 831, at 20.

873 Though the AEC claims that its decisionmaking procedures "generally operate with reasonable speed considering the interests and issues" that are dealt with, RESPONSES, supra note 30 , at 787, the hearing time has increased geometrically in the past few years. See Ellis \& Johnston, supra note 831, at 23. The average hearing time has increased more than twenty-five fold in the past four years. Id. 21.

A recent example of the burden which public intervenors may impose on the administrative process is found in the Shoreham, N.Y., construction permit proceeding. Hearings were held intermittently from Sept. 21, 1970, through Nov. 1971, and AEC officials estimate that it could be at least mid-1972 before a construction permit could issue. See N.Y. Times, Nov. 4, 1971, at 94, col. 1. The Lloyd Harbor Study Group, a local conservation organization with the support of a number of national groups, contributed to the length of the proceedings by conducting extensive cross-examination of witnesses for both the AEC and the applicant. The length of the Shoreham hearings may be compared to the three or four days consumed in other similar hearings. See N.Y. Times, Jan. 24, 1971, at 44, col. 4.

874 Ellis \& Johnston, supra note 831, at 20. See note 862 supra \& notes 893-913 infra \& accompanying text.

875 See note 886 infra \& accompanying text.

876 See, e.g. Pacific Gas \& Elec. Co. (Diablo Canyon Unit 2), 2 CCH Atom. EN. L. REp. đI1 1990.01 (1970) (8 petitions to intervene); Toledo Edison Co. \& Cleveland Elec. Illuminating Co. (Davis-Besse Nuclear Power Station), 2 CCH

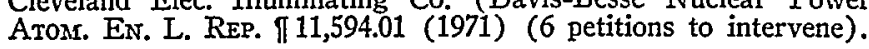


public interest groups have participated as parties in opposition to an application. ${ }^{877}$

There has also been a substantial increase in the number of challenged operating licenses, and delay at that point in the construction and operating process is very costly to the utility. ${ }^{878}$ It has been suggested that

[ $t$ ] he proliferation of contested operating-license hearings has stemmed in part from the limited opportunity for, and the restricted statutory scope of, public participation in the construction-permit hearings. It is also due in part from interveners being more than willing to take two bites at the apple when offered. ${ }^{879}$

The detrimental impact of such delay cannot be overemphasized. ${ }^{880}$ Concerned representatives of both industry and environmentalist groups have cited the inadequacy of $\mathrm{AEC}$ procedures as a major cause of the problem, suggesting not only a re-examination of public hearing procedures, but also a complete restructuring of the licensing process. ${ }^{881}$

\section{c. Standing of Parties to Raise Particular Issues}

Public intervenors have rarely been absolutely denied the opportunity to participate in Commission hearings, ${ }^{882}$ but intervention has been granted on the condition that issues deemed beyond its jurisdiction not be raised. Alternatively, intervention may be granted unconditionally, but the board may refuse to consider extra-jurisdictional evidence.

(i) Challenges to the Applicant's Safety Analysis

At the construction permit hearing the basic inquiry has been whether the nuclear facility can be safely operated. ${ }^{883}$ A construction

877 Ellis \& Johnston, supra note 831 , at $42-43$; cf. I. Like, Multi-Media Confrontation-The Environmentalists' Strategy for a "No-Win" Agency Proceeding (1971) (advocating that public intervenors use the administrative arena as a forum to educate the public and transform agency hearings into a dramatic medium to expose environmental issues). The nuclear power industry is extremely concerned with dilatory tactics adopted by public intervenors with the purpose of imposing stricter requirements. See Statement of Myron M. Cherry on Behalf of Friends of the Earth, Hearings on AEC Licensing Procedure \& Related Legislation Before the Subcomm. on Legislation of the Joint Comm. on Atomic Energy, 92d Cong., 1st Sess., pt. 1, at 385, 390-91, 403-04 (1971) [hereinafter cited as Cherry Statement].

878 Ellis \& Johnston, supra note 831, at 35 ; cf. Cavers, supra note 832, at 249.

870 Ellis \& Johnston, supra note 831 , at 35.

880 Long Island Lighting Co. estimates that continued delay in the Shoreham, N.Y., construction permit hearings "would cost a minimum of $\$ 1$-million a month." N.Y. Times, Nov. 4, 1971, at 94, col. 1 . Of course, much of this cost will be passed on to the consumer.

881 See, e.g., N.Y. Times, Nov. 13, 1971, at 38, col. 5 (research director for Lloyd Harbor Study Group cites inadequate hearing methods as a cause of delay at Shoreham hearings); Smith, An Energy Threat, N.Y. Times, Nov. 7, 1971, \$3, at 26, col. 4 (H. W. Winterson, president of the Atomic Industrial Forum, calls for a complete restructuring of licensing procedures).

882 See notes 844-47 supra \& accompanying text.

883 Green, supra note 835 , at 640 . 
permit is to be issued only after the AEC considers the "health and safety of the public." 884 Because of the exceedingly technical issues involved in reviewing the applicant's and the AEC staff's safety analysis ${ }^{885}$ and the "difficulty in obtaining the technical expertise to perform the type of detailed, careful study performed by the regulatory staff and by ACRS," ${ }^{886}$ intervenors have heretofore rarely challenged reactor design. As public interest organizations become more sophisticated and better financed, the role of intervenors may be more constructive. ${ }^{87}$ Though no reactor design has ever been altered as a result of a public hearing, ${ }^{88 s}$ intervenors have successfully influenced applicants to withdraw applications or to reach a settlement. The intervenors in the Bodega ${ }^{889}$ and Malibu ${ }^{800}$ cases, alleging that there were undue earthquake hazards, successfully discouraged the siting of reactors near fault lines. Public intervenors have also exacted quality control concessions from the nuclear reactor industry, ${ }^{891}$ resulting in industry concern with the "serious problems" of public disclosure caused by "professional dissidents." 892

\section{(ii) Challenges to Environmental Effects}

The AEC's narrow view of its jurisdiction over nonradiological environmental matters has led to the denial of standing of intervenors

88442 U.S.C. $\$ 2133$ (b) (1970).

885 For a layman's outline of the technical issues involved in a safety analysis, see J. Hogerton, Atomic Power Safety 20-32 (1964).

886 Ellis \& Johnston, supra note 831, at 55-56. The cost of acquiring legal and expert aid, see $i d .50-51$, and the reluctance of qualified experts to testify against a project recommended by the AEC, see Like, supra note 877 , at 11, are large obstacles faced by intervenors in safety hearings. It has been suggested that public intervenors should be provided "with access to scientific expertise and financial resources to enable the public intervenor more effectively to participate in public hearings." Cherry Statement, supra note 877, at 393. 398-99.

887 See Cavers, supra note 832, at 253; Cherry Statement, supra note 877, at

888 Ellis \& Johnston, supra note 831, at 25.

889 The applicant withdrew its application after an adverse staff report on the suitability of the site. See Proposed Nuclear Power Plant at Bodega Head by Pac. Gas \& Elec. Co., 2 CCH AtoMr. EN. L. REP. $\llbracket 11,261$ (1964); Green, supra note 835, at 642 n.64; Cavers, supra note 832, at 247.

890 In the Malibu case, the hearing resulted in a conditional initial decision for the applicant. Department of Water \& Power (Malibu Nuclear Plant Unit No. 1), 3 A.E.C. 122 (1966), but the board's authorization of a provisional construction permit was set aside and remanded for amendments to the application, 3 A.E.C. 179 (1967). The applicants then withdrew their application. Ellis \& Johnston, supra note 831 , at 25 .

891 See Cherry Statement, supra note 877, at 398-402. Cherry recounts several cases in which intervenors were able to raise safety problems constructively and to participate in settlement agreements in which the applicant made important concessions. See, e.g., Palisades Plant Settlement Agreement between Intervenors and Consumers Power Co. (1971), copy on file in Biddle Law Library, Univ. of Pa. Law School.

892 Cherry Statement, supra note 877, App. C, at 415. The quote is from the record of a 1970 seminar on AEC hearings conducted at Gaithersburg, Md., for the nuclear power industry. A large part of the seminar was devoted to the problems caused by intervenors and how to mitigate their impact, including the "proper maintenance" of records that may be susceptible to damaging discovery. Id. 402 . 
to raise such issues as thermal pollution and aesthetics at licensing hearings. ${ }^{893}$ Prior to the National Environmental Policy Act ${ }^{894}$ the AEC consistently adhered to a position that its authority did not extend to the consideration of environmental effects not directly related to problems of atomic radiation. ${ }^{895}$

In the case of Vermont Yankee Nuclear Power Corp. ${ }^{896}$ the states of New Hampshire, Vermont, and Massachusetts unsuccessfully attempted to offer evidence into the hearing relating to the possible thermal pollution of the Connecticut River resulting from a proposed nuclear power plant. At the outset of the hearing, the board advised that

[q]uestions about other aspects of health and safety or other aspects of the plant not falling within the areas of radiological health and safety and the common defense and security are not within the AEC's jurisdiction and will not be considered at this hearing. Thus, we will not consider such matters as the possible thermal effects, as opposed to the radiological effects, of the facility operation on the environment; the effect of the construction of the facility on the recreational, economic or political activities of the area near the site; or matters of aesthetics. ${ }^{897}$

On appeal the Commission affirmed the board's exclusion of the evidence on the grounds that those issues were beyond the jurisdiction of the board and that the Commission's rules of procedure prohibited their consideration. ${ }^{898}$ The Commission also noted that the admission of such evidence would constitute a change or enlargement of the issues specified in the notice of hearing and thus would breach the condition under which the states had been permitted to intervene. ${ }^{809}$ The states appealed the grant of the construction permit, alleging as error the

893 See, e.g., Thermal Ecology Must Be Preserved v. AEC, 433 F.2d 524 (D.C. Cir. 1970); Consolidated Edison, Inc. (Indian Point Nuclear Generating Unit 3), 2 CCH Atom. EN. L. Rep. \11,579.01 (1969).

The recently expanded jurisdiction of the AEC to hear antitrust complaints, see note 862 supra, will not be discussed.

89442 U.S.C. $\$ \$ 4321-47$ (1970).

895 See New Hampshire v. AEC, 406 F.2d 170 (1st Cir.), cert. denied, 395 U.S. 962 (1969). See also letter from Glenn T. Seaborg to Senator Muskie, Nov. 4, 1967, in Hearings on Licensing \& Regulation of Nuclear Reactors Before the Joint Comm. on Atomic Energy, 90th Cong., 1st Sess. 980 (1967).

The Commission interpreted its mandate to issue a license only when it is not "inimical ... to the health and safety of the public," 42 U.S.C. $\$ \$ 2133$ (d), 2134(d) (1970), to refer only to dangers arising from the hazards of radioactivity. See letter from Harold I. Price, AEC Director of Regulation, to Senator Muskie, Oct. 23, 1967, in Hearings on Licensing \& Regulation of Nuclear Reactors Before the Joint Comm. on Atomic Energy, 90th Cong., 1st Sess. 977 (1967). See also Note, supra note 828 , at $764-65$.

8962 CCF Atom. En. L. Rep. $\{11,267.02$, at 17,503 (1967).

$897 I d$. at $\llbracket 11,267.04$, at $17,503-5 \mathrm{n} .2$.

$898 \mathrm{Id}$. at $\Uparrow 11,267.03$, at $17,503-5$.

899 Id. 
Commission's refusal to consider evidence of thermal pollution. The court thoroughly analyzed the legislative history of the Atomic Energy Act and concluded that the Commission's responsibility was limited to "scrutiny of and protection against hazards from radiation." 900

The NEPA has changed this situation, declaring "a national policy which will encourage productive and enjoyable harmony between man and his environment [and] promote efforts which will prevent or eliminate damage to the environment . . . " 901 All federal agencies are directed, "to the fullest extent possible," to

include in every recommendation or report on proposals for legislation and other major Federal actions significantly affecting the quality of the human environment, a detailed statement by the responsible official on-

(i) the environmental impact of the proposed action,

(ii) any adverse environmental effects which cannot be avoided should the proposal be implemented,

(iii) alternatives to the proposed action,

(iv) the relationship between local short-term uses of man's environment and the maintenance and enhancement of long-term productivity, and

(v) any irreversible and irretrievable commitments of resources which would be involved in the proposed action should it be implemented. ${ }^{902}$

Despite the NEPA's sweeping language, the AEC moved slowly in adopting regulations to conform to its mandate. ${ }^{.03}$ Though the promulgated rules did provide that intervenors would be permitted to raise environmental issues at construction permit hearings, ${ }^{904}$ the Commission's implementation of the NEPA limited the scope of environmental issues that may be considered in the decisionmaking process. ${ }^{905}$

The opinion of the Court of Appeals for the District of Columbia Circuit in Calvert Cliffs' Coordinating Committee v. AEC ${ }^{908}$ severely criticized the AEC's minimal response to the NEPA. The petitioners in Calvert Cliffs challenged the AEC's rules ostensibly effectuating the NEPA, alleging that the rules limited full consideration and balancing

900 New Hampshire v. AEC, 406 F.2d 170, 175 (1st Cir.), cert. denied, 395 U.S. 962 (1969).

90142 U.S.C. $\$ 4321$ (1970).

90242 U.S.C. $\$ 4332(2)$ (c) (1970).

903 NEPA went into effect on Jan. 1, 1970, but a formal change in the AEC rules implementing NEPA was not announced until Dec. 3, 1970. See Calvert Cliffs' Coordinating Comm. v. AEC, 449 F.2d 1109, 1116 (D.C. Cir. 1971).

904 See 35 Fed. Reg. 18,474, đ11(a) (1970).

905 Ellis \& Johnston, supra note 831 , at 27 ; Like, supra note 877 , at 18.

900449 F.2d 1109 (D.C. Cir. 1971). 
of environmental values. The petitioners specifically attacked provisions providing that hearing boards need not consider the environmental impact of a licensed reactor unless that issue is affirmatively raised by a party, ${ }^{907}$ and that boards are prohibited from conducting an independent evaluation of environmental factors if other federal or state agencies have certified that their standards are satisfied. ${ }^{908}$ The court remanded the case, directing that "the Commission must revise its rules governing consideration of environmental issues." ${ }^{09}$ The court made it clear that the Commission may not permit licensing boards to adopt the option of admitting evidence concerning nonradiological effects only to ignore it in the decisionmaking process:

NEPA requires that an agency must-to the fullest extent possible under its other statutory obligations-consider alternatives to its actions which would reduce environmental damage. That principle establishes that consideration of environmental matters must be more than a pro forma ritual. Clearly, it is pointless to "consider" environmental costs without also seriously considering action to avoid them. Such a full exercise of substantive discretion is required at every important, appropriate and nonduplicative stage of an agency's proceedings. ${ }^{910}$

The Commission has revised its rules consistent with the opinion. ${ }^{911}$ Calvert Cliffs has informed the AEC that the NEPA requires a substantive change in the Commission's narrow interpretation of the "health and safety of the public." Both the expanded jurisdiction and the justification for it given in Calvert Cliffs have been criticized on the grounds that jurisdiction over environmental impact is already vested in other bodies and that AEC consideration is thus redundant as well as of little potential benefit in view of the AEC's exhibited biases. ${ }^{912}$ This redefinition of the Commission's statutory licensing responsibilities will, however, provide public intervenors an opportunity to raise a broad spectrum of environmental issues at construction permit

907 See 35 Fed. Reg. 18,474, đ 13 (1970).

908 See id. $\int 11$ (b) ; cf. Ellis \& Johnston, supra note 831, at 27-28. The complaint also attacked the regulations which prohibited the raising of nonradiological issues in cases where the notice for the hearing appeared before Mar. 4, 1971, 35 Fed. Reg. $18,474, \pi 11$ (a) (1970), and which stated that, for any construction permit issued prior to that date, the Commission would not formally consider environmental factors until the time for issuance of an operating license, $i d$. $\Uparrow 14$.

909449 F.2d at 1129.

$910 I d$. at 1128 (emphasis in the original).

Consumers Power Co. of Jackson, Mich., has filed a petition for a rehearing of Calvert Cliffs, stating that the new AEC regulations make the situation "particularly acute" for its Palisades plant. 2 [Current Developments] BNA ENv. Rep. 548 (Sept. $10,1971)$.

91110 C.F.R. $\$ 50$, App. D (1972).

912 Tarlock, Tippy \& Francis, Environmental Regulation of Pozer Plant Siting: Existing and Proposed Institutions, 45 S. CAL. L. Rev. 502, 534-38 (1972). 
hearings, and this expanded jurisdictional base will undoubtedly have a significant impact upon the number of parties seeking to intervene and upon the time consumed by the hearing. ${ }^{913}$

\section{d. Conclusion}

The standing of a party to raise particular issues is strongly influenced by the AEC's definition of its limited jurisdictional authority. While the public has long been allowed to speak to safety problems during the construction permit hearing, its effectiveness has been limited by a lack of technical expertise and by the fact that the hearing is no more than a public corroboration of the regulatory staff's review of an application. With the advent of "the new breed of intervenors" 114 and the NEPA, the public will have a larger role in assuring that both safety and environmental considerations will be fully deliberated.

The AEC has only recently been faced with the administrative problems accompanying hearings with large numbers of intervening parties. The broadening of the Commission's decisionmaking responsibilities and the anticipated increase in license applications are likely to demand procedures to insure that hearings are conducted in an orderly fashion. The adoption of rules providing boards with guidance in dealing with the problems of multiple intervenors and of limited appearances has already been suggested. ${ }^{915}$ When acting on a petition to intervene or when determining whether to admit evidence on a particular issue, boards should look not only to whether the intervenor alleges interests which may be affected by the proceeding but also to what the petitioner will contribute, if permitted to participate fully in the hearing. ${ }^{916}$ Perhaps more important to the efficient conduct of future AEC hearings is the promulgation of more definite standards expressing Commission policy on recurring issues. ${ }^{917}$ Setting forth such rules once, through the

913 Ellis \& Johnston, sispra note 831 , at 26-28. The real impact of the Calvert Cliffs decision upon the status of intervenors has already been demonstrated. The $A E C$, in authorizing a public hearing on the grant of an operating license for the Maine Yankee Atomic Power Plant, reversed its prior position and granted previouslyrejected petitions to intervene by three conservation groups. See N.Y. Times, Nov. 14 , 1971, at 24, col. 1 .

914 Cherry Statement, supra note 877 , at 387.

915 See notes 853-57 supra \& accompanying text.

910 See Ellis \& Johnston, supra note 831, at 54 ("Intervention should be restricted to those who have shown any interest in the case which will not otherwise be represented by any other party and which is related to the limited issues raised by answers to [an] order to show cause.").

917 Id. 45-46, 66. This technique has been successfully utilized; the Commission has passed a rule stating that an application for a construction permit need not provide design features for the purpose of protecting a facility against enemy attack and sabotage. See 10 C.F.R. $\$ 50.13$ (1972). This rule may be used by a licensing board as grounds for denying an intervenor the opportunity to cross-examine an applicant on the attack and sabotage issues. See Siegal v. AEC. 400 F.2d 778 (D.C. Cir. 1968).

Several commentators have suggested that AEC proceedings could be expedited by providing a public licensing hearing only in contested cases where the prospective intervenor has "shown cause." Ellis \& Johnston, supra note 831, at 47-57. 
rulemaking process, rather than repeatedly in adjudicative-permit proceedings, would allow public protestants to participate more effectively in the establishment of licensing criteria and would expedite individual licensing cases.

\section{Proposals to Unify Power Plant License Decisionmaking}

From such cases as Scenic Hudson and Calvert Cliffs, it is apparent that an ad hoc approach to power plant licensing prevails in both the FPC and the AEC. Criticism of such an approach, and its tendency to produce decisions that disregard the overall balance of costs and benefits to society, may be viewed as an issue wholly distinct from the issue of the proper role and scope of public participation in agency decisions. Either an ad hoc or an integrated decisionmaking process could, for example, proceed by totally excluding the public or by providing limited opportunity for comment on formal decisions. Indeed, one may imagine that there exist groups representing particular segments of the public that would benefit in particular cases by retention of ad hoc decisionmaking - the most obvious example being an association of politically influential local property owners opposing construction of a facility that would face less opposition if placed in an area more densely populated but less influential or more disorganized.

Despite these possibly ambivalent results of the integration of decisionmaking, those who favor increased public participation in power plant siting decisions have advocated this reform with at least as much vigor as have members of the industry ${ }^{918}$ and the agencies. ${ }^{919}$ For example, Judge Irving Kaufman, a veteran of the litigation surrounding the licensing of the Storm King Mountain power plant, has strongly suggested such integration because he sees it as a cure for the problems confronting public participants and the problems they, at least in part, have in turn precipitated:

Specifically, I submit that, because of the absence of an agency with a broad perspective and broad planning authority, the ultimate decision whether to license the Storm King plant and other electric power plants is unreasonably delayed and public participation in the decision unduly restricted, however open the proceedings may be theoretically. ${ }^{920}$

This view suggests that the scope of public discussion before an agency depends on the scope of the agency's responsibility as well as the legislative standards set for the agency's action. Concerning Scenic Hudson, Judge Kaufman observed:

918 See, e.g., Lowenstein, The Need for Separation of the AEC's Functions, 13 Aтom. EN. L.J. 282 (1971).

919 See Nassikas, supra note 742.

920 Kaufman, Power for the People-and by the People: Utilities, the Environment and the Priblic Interest, 46 N.Y.U.L. REv. 867, 873 (1971). 
The basic defect in the process, as I see it, was the inevitably narrow scope of the decision the agency had to make: whether or not to license a single and specific electric generating plant. The narrow scope of the decision before the agency led necessarily to a strictly limited discussion of the issues by the public. Questions of other possible sites or of a planned dispersal of power plants and the like could not be discussed by public interest groups because these issues were not before the agency. ${ }^{921}$

The FPC is now required to approve only power facilities that comport with a "comprehensive plan." Apparently recognizing that such a term is too broad to be very useful, the court in Scenic Hudson looked to the more specific statutory language following the term in order to find a responsibility in the agency to consider "recreational" uses. ${ }^{922}$ By comparison the AEC, which certifies facilities already subject to regulation by the $\mathrm{FPC},{ }^{923}$ is charged with regulating to serve the public interest. These broad standards for agency action are practically meaningless where "regulation is sadly fragmented between various levels of government." 924 The passage of the NEPA with its particular substantive values, and the Calvert Cliffs litigation following that enactment, demonstrate convincingly the muddled, compartmentalized concept of regulatory responsibility that has resulted in the power industry. Lapses in regulation are virtually certain to result as a consequence of each agency's decision that certain foreseeable costs of a siting decision should be disregarded because not relevant to that agency's "limited" area of responsibility. ${ }^{925}$

Proposals for restructuring the regulation of the electric power industry now commonly focus on balancing the two needs about which debate has recently centered: environmental protection and power needs. One bill which the Nixon administration has presented to Congress in response to calls for restructuring does not attempt to unify regulation fully, but it moves in that direction by consolidating federal regulation and subjecting state regulation to federal oversight. ${ }^{928}$ At the same time, the bill would establish more meaningful-and perhaps enforceable-standards for agency action, by charging the federal authority to ascertain that a proposed facility "will not unduly impair important environmental values and will be reasonably necessary to meet electric power needs." ${ }^{927}$ Although these terms conceal myriad costs and bene-

921 Id. 872.

922354 F.2d at 614.

923 See note 722 supra \& accompanying text.

924 Tarlock, Tippy \& Francis, Environmental Regulation of Power Plant Siting:

Existing and Proposed Institutions, 45 S. CAL. L. REv. 502, 505 (1972).

925 See notes 767, 882-913 supra \& accompanying text .

926 H.R. 5277, $92 d$ Cong., 1st Sess. (1971).

927 Id. $\$ 8(\mathrm{c})$. 
fits, their use nonetheless suggests a limited regulatory perspective under the unified control established. In view of the general unwillingness of the FPC and AEC to broaden their perspectives when pressured by members of the public, 928 the use of terms more specific than "public interest" may make even less likely agency response to new concerns when now-silent members of the public appear to champion them.

Within the context of reforms directed at consolidation of regulation for the purpose of balancing a limited number of goals, the nature of public participation remains a problem. One recent article ${ }^{229}$ has examined a one-step licensing procedure adopted in 1970 in the state of Washington and has made an observation that applies to public participation as well as to the regulation focused upon:

The Washington experience indicates that one-stop licensing can be either a means of preventing delays in plant construction, or a means of shielding utilities from regulation by agencies that have a statutory mandate to improve environmental quality. ${ }^{930}$

Unified regulation is a means of streamlining decisionmaking, not a means of making that regulation more open or more careful. Seen from this perspective, Judge Kaufman's proposal is but a sine qua non to effective public participation, not a way of ensuring it. Indeed, the Chairman of the Federal Power Commission has discussed the proposal in terms suggesting that it would reduce at least some, potentially harmful, dimensions of public participation:

$[\mathrm{T}]$ here is the question of just how many times general public participation is to be allowed in respect to the location of specific utility facilities. Those who are close followers of legislative siting proposals before the Congress and various state legislatures, will recognize that I am referring to the one-stop problem. ${ }^{931}$

Unifying the regulation of the power industry, then, is not a panacea for the frustrated public that wishes to participate. It should be, however, the occasion for a reexamination of the proper role of the public participant, if for no other reason than the fact that the restructuring will necessarily settle the issues. The number of specific proposals recently put forward and the fluidity of the current situation precludes detailed examination in the space available here. Certain conclusions drawn from the discussions of the FPC and the AEC above should be re-emphasized here, though, for they lend support to some of the programs proposed. Participation by the public as full parties in multiple,

928 See notes 767, 882-913 supra \& accompanying text.

929 Tarlock, Tippy \& Francis, supra note 912.

930 Id. 555.

931 Nassikas, supra note 742, at 113. 
formal power plant licensing hearings has been a conspicuously defective device for implementing the full, open debate called for by this Comment. Consolidation in one proceeding of particular and general questions concerning both technology and policy has made participation an enormous undertaking, and has thus effectively foreclosed all but a few strongly motivated and well financed members of the public. Putting the burden on the parties to back normative arguments with technological data showing feasibility has only increased this problem. Public participation should not mean participation by a few interest groups outside the regulated industry, and reform ought to focus sharply on eliminating these problems. Combined with a conscious articulation of the scope of a unified agency's regulatory responsibility that provides channels for easy entry of emerging groups of concerned individuals, this provision for more effective but limited participation will go far toward improving the decisionmaking process.

FPC Chairman Nassikas, while supporting broad public participation, has advocated reforms that may actually foreclose the public from formal hearings completely. He has suggested that there be substituted an earlier and ongoing process of opinion and information gathering, which, without further details, is called a "collaborative analytic process." ${ }^{932}$ While it is easy to agree that full participation in formal hearings has been unsatisfactory in the regulated power industry, suggestions that decisions should be "collaborative" must be viewed with scepticism, for they may be no more than a call for a return to captive regulation. A more promising possibility has been advanced by Professor Jerre Williams of the University of Texas. ${ }^{933}$ Public participation would be accomplished through a bifurcated hearing structure and the creation of a public counsel. One hearing would be "advisory," conducted informally and open to any interested person or group; the other would be similar to the licensing hearing now in use, and the public would be represented as a full party by the public counsel. Backed by a requirement that written submissions be freely accepted from the public in both proceedings and included in a record available for purposes of review, this structure is at least a step in the right direction. Perhaps supplemented by a requirement that the public counsel participate in the informal hearing, this would guarantee competent representation of the public in the formal decisionmaking process while offering significant hope that the public counsel thus appearing will not himself become a captive of the institution and its views. While the informal hearing should be the primary forum for wideranging debate, an outside voice in the formal proceeding should be retained in order both to allow rebuttal on issues raised by the parties to the formal proceeding and to hold open a door to effective judicial review.

932 Id. 112.

933 Williams, Public Participation in Locating Facilities Dedicated to Public Use, 88 Pub. UTIL. Fort., Sept. 16, 1971, at 101 (1971). 


\section{CONCLUSION}

Public participation in federal agency decisionmaking is not, of course, an end in itself. Rather it is only one means to insure that regulation in fact furthers the "public interest." As noted in the first section of this Comment, one of the most frequent criticisms directed at the federal agencies is that they favor and too often accommodate the desires and ends of the regulated industries. Attacks on the decisionmaking process are now loudest from currently "unrepresented" groups - consumers and conservationists predominating.

The problem goes deeper, however. If the response to these criticisms is no more than an adjustment admitting the most organized and well financed groups to a position of influence, it is doubtful that the decisionmaking process will have been fundamentally improved. As this Comment has noted, courts have taken numerous steps within the confines of existing statutory schemes to open agency decisionmaking to fuller debate and closer judicial scrutiny. But in taking these steps, courts have favored "responsible" participants or group representatives without exploring the implications of such restrictions for agency policy evolution.

Where the channels for public participation in agency decisionmaking are adversary hearings and judicial review, one consequence is that the costs of private litigation impose significant restraints. Another consequence is that essentially political decisions are made not by the agencies, but by courts relying as best they can on the vague statutory standards established for regulatory action.

Statutory reform with the goal of emphasizing other channels for public participation may be the most desirable direction in which to move. The prior failure of the agencies to make greater use of rulemaking may be a primary cause of current problems. If the agencies will not voluntarily engage in open, broadly debated, formalized policy formulation, statutory measures to force them to take these steps are appropriate. Where such measures have been enacted, judicial review could be limited to cases where individual hardships appear.

As this Comment has detailed, however, much can be done within existing statutory frameworks. Public participation generally is, and should be, promoted where the agency is making choices based on essentially political rather than technological grounds. In the areas subject to FCC regulation, where the technological framework has become relatively stable, both the public and the courts have readily entered individual controversies. On the other hand, every decision by the FPC or AEC to license a power plant involves complicated technological judgments, hardly susceptible to the type of debate possible within FCC proceedings. Nevertheless, sharper delineation of the political choices made by these agencies is clearly possible and frequently suggested. Recognizing the practical constraints on maintaining full 
party status in agency adjudications, flexible techniques for limited participation should be increasingly developed. At the same time courts, agencies, and legislatures should seek ways to minimize the economic burden placed on members of the public who seek to put relevant information before the agency and prod agency action in the public interest. 